\title{
Environmental forensics for characterization of unexploded ordnance in soils at the Dolly Sods Wilderness Area
}

Amy Richmond Aylor

West Virginia University

Follow this and additional works at: https://researchrepository.wvu.edu/etd

\section{Recommended Citation}

Aylor, Amy Richmond, "Environmental forensics for characterization of unexploded ordnance in soils at the Dolly Sods Wilderness Area" (2008). Graduate Theses, Dissertations, and Problem Reports. 2604.

https://researchrepository.wvu.edu/etd/2604

This Thesis is protected by copyright and/or related rights. It has been brought to you by the The Research Repository @ WVU with permission from the rights-holder(s). You are free to use this Thesis in any way that is permitted by the copyright and related rights legislation that applies to your use. For other uses you must obtain permission from the rights-holder(s) directly, unless additional rights are indicated by a Creative Commons license in the record and/ or on the work itself. This Thesis has been accepted for inclusion in WVU Graduate Theses, Dissertations, and Problem Reports collection by an authorized administrator of The Research Repository @ WVU. For more information, please contact researchrepository@mail.wvu.edu. 
Environmental Forensics for Characterization of Unexploded Ordnance in Soils at the Dolly Sods Wilderness Area

Amy Richmond Aylor

Master of Science

in

Chemistry

Suzanne C. Bell, Ph.D., Chair

John D. Quaranta, Ph.D., P.E.

Keith B. Morris, Ph.D.

C. Eugene Bennett Department of Chemistry

Morgantown, West Virginia

2008

Keywords: Chemistry, Analytical, Environmental, Trinitrotoluene, TNT, RDX, HMX, soil analysis, West Virginia Maneuvers Area, Dolly Sods Wilderness Area, HPLC, high performance liquid chromatography 


\section{Abstract \\ ENVIRONMENTAL FORENSICS FOR THE CHARACTERIZATION OF UNEXPLODED ORDNANCE IN SOILS AT THE DOLLY SODS WILDERNESS AREA}

\section{by Amy Richmond Aylor}

The West Virginia Maneuver Area includes locations within the Dolly Sods Wilderness Area, the Canaan Valley National Wildlife Recreation Area, and private land holdings in Grant, Randolph, and Tucker counties of West Virginia. Between 1943 and 1944, the military trained troops in a 50,000 acre area which is now the Dolly Sods Wilderness area. This training was conducted by the U.S. Department of the Army and involved artillery and mortar training for troops destined for World War II combat in the mountains of Italy. This project focused on characterization and investigation of the environmental contamination resulting from military ordnance existing within areas of the West Virginia Maneuver Area, including the Dolly Sods Wilderness Area - North, Canaan Valley National Wildlife Refuge, and private land holdings in Canaan Valley, West Virginia. Field sampling campaigns were performed in July and August 2007. Field sampling procedures followed USEPA Method 8330b multi-increment sampling. Concentrations of explosive residues and their degradation products are reported for soils retrieved from these areas and analyzed using high performance liquid chromatography (HPLC) coupled with UV-vis detection. The combination of RDX/HMX was found to be present in soils on the surface and to a depth of at least $20.3 \mathrm{~cm}(8 \mathrm{in}$.) in this research. 


\section{ACKNOWLEDGEMENTS}

I would like to thank Dr. Suzanne Bell for supporting the many pursuits that have comprised my journey as a graduate student. Her enthusiasm for education (and life) certainly kept the days interesting. Without her patience and efforts, my graduate education would not be what it is. I sincerely appreciate the guidance Dr. John Quaranta has offered throughout this project. His level of organization held the work together on many occasions and his gentle wisdom and demeanor have provided me with much inspiration. Without his dedication and participation, I would not have had the opportunity to be a part of such a worthy endeavor. I would also like to thank the third member of my thesis committee, Dr. Keith Morris, for his advice, his constructive criticism, and (of course) his song. Without the pleasure of his company and service, my time at West Virginia University would not have been quite the experience it has been.

I would like to thank my husband, Will, our canine charges, Vedder and Fredo, and our son, Maddock, for providing the motivation to see this pursuit through, the support at the end of each day during the process, and the purpose for attempting each new endeavor to come. I would also like to thank my parents, Paul and Julie Richmond, my siblings, Mike Richmond and Tracy Gomer, and my nephew, Christopher Gomer for their constant presence, unconditional love, and never-wielding patience. I am overwhelmed with the good fortune to be part of such a special and invaluable family.

I could never have accomplished this research without the tireless efforts of Melissa Ely and Lucy Oldfield. Through the rain, the mud, the long hours (and hikes), instrument malfunctions, and presentations, I could always count on these ladies to see me through. Jen Fulton provided countless hours of work on the GIS framework and editing of this manuscript, work for which I am forever grateful. I was also fortunate to work with three of the most dedicated undergraduates that anyone could ask for. Tenele Zito, Mary Beth Tajc, and Yuka Takeshima went above and beyond any expectations anyone had for their contribution. Without a doubt, the project could not have been completed in such a timely fashion without the efforts of these three ladies. There are no words to describe how unenjoyable this experience would have been as a solo effort. In addition to my partners on this project, I have had the great fortune to be surrounded with some of the most kindred spirits one could hope for (especially in the field of chemistry). I truly looked forward (most days) to coming to work knowing that I had such a special group to work with. Very few people can say that. I could never repay any of my colleagues or thank them enough for all they have done for me.

I would like to acknowledge the National Environmental Education and Training Center (NEETC), Indiana, PA for funding this project through research grant \#1003786R.

I would like to thank the US Army Corps of Engineers - Huntington WV District Office (Mr. Rick Meadows, P.E., and Mr. Nick McHenry, and Mr. Walter Zange of the Huntsville, AL Engineering and Support Center) for their interest and involvement in the project, the US Army Corps of Engineers - Engineer Research and Development Center for providing UXO multiincrement sampling and analysis training, the US Forest Service, Elkins WV (Mr. Jeff Hammes and Ms. Stephanie Connolly) and the US Fish and Wildlife Service - Canaan Valley National Wildlife Refuge (Mr. Jonathan Schafler, Ms. Lea Ceperley, and Mr. Ken Sturm) for assisting with project oversight and site access, the West Virginia Department of Environmental Protection Division of Land Restoration ( Mr. Don Martin) for assisting with project information, and Mr. Ken Dzaack of the Canaan Valley Institute for assistance with UXO site identification and site access permission. 


\section{TABLE OF CONTENTS}

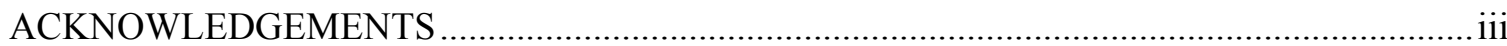

TABLE OF CONTENTS ................................................................................................ iv

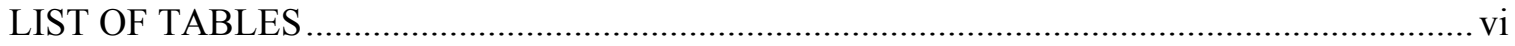

LIST OF ACRONYMS ………………………………………………………………

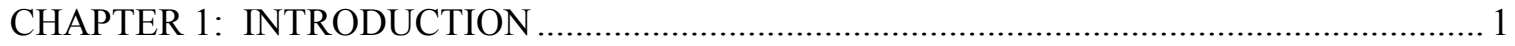

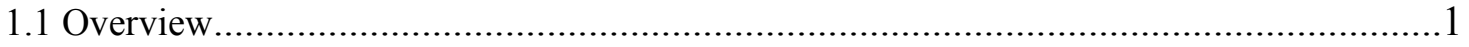

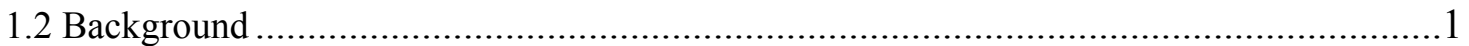

1.3 History of Environmental Explosives Detection .............................................................

1.4 Background on Explosives Analyzed in this Project ......................................................

1.4a. Physical and Chemical Properties of TNT, RDX, and HMX ...................................... 3

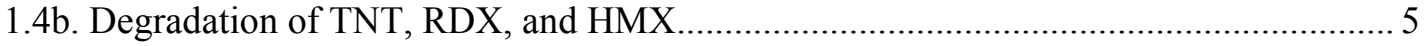

1.4c. Human Toxicity of TNT, RDX, and HMX ……………………………………... 7

1.4d. Ecological Toxicity of TNT, RDX, and HMX...................................................... 8

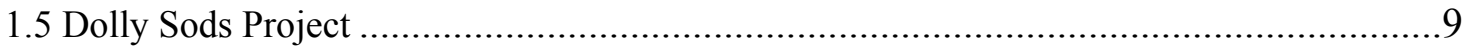

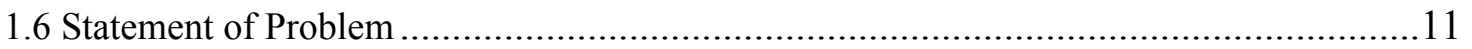

CHAPTER 2: MATERIALS AND METHODS .............................................................. 14

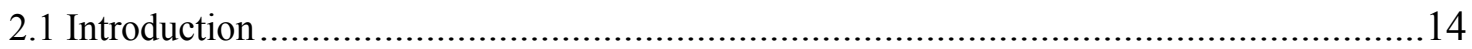

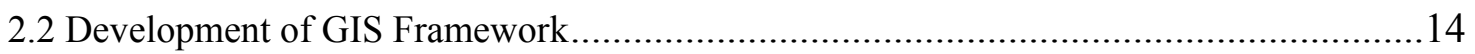

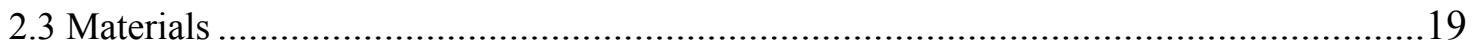

2.4 Soil Sampling Methods …………………………...........................................19

2.4a. Composite (bias) grab sampling ……………………………………………. 20

2.4b. Multi-increment Sampling ……………………………………………….... 20

2.4c. Depth Profile Sampling ....................................................................................... 22

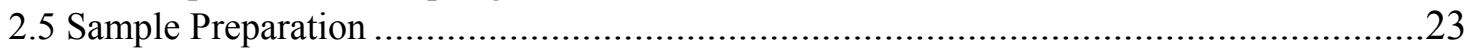

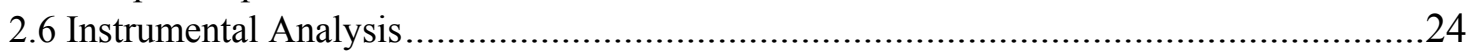

CHAPTER 3: SITE DESCRIPTIONS AND DEVIATIONS FROM SAMPLING PLAN ..........26

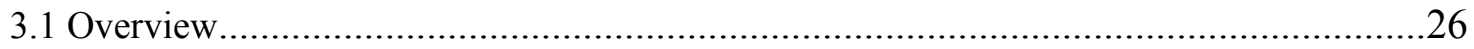

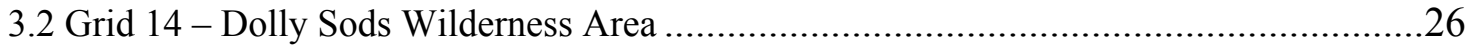

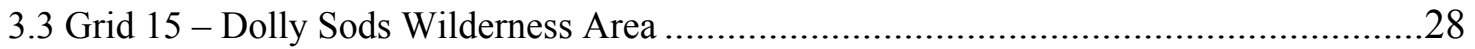

3.4 Grid 16 - Canaan Valley National Wildlife Reserve ………………….......................29

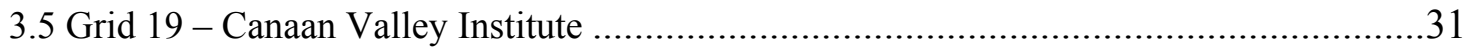

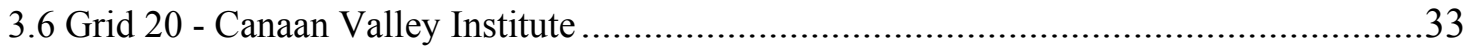

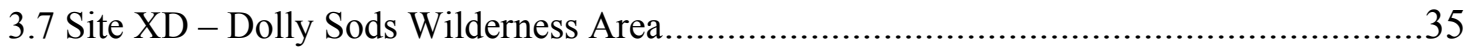

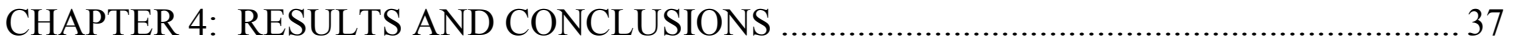

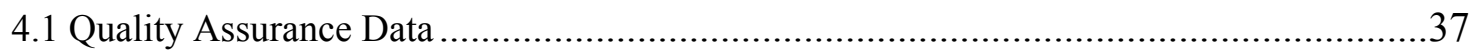

Instrument Validation .................................................................................................... 37

ERA Certified Reference Material .................................................................................... 37

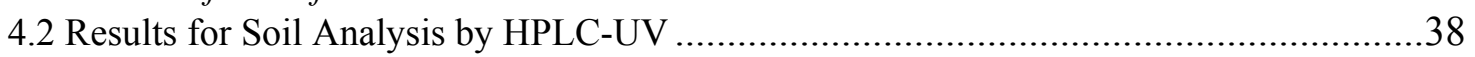

4.2a Results for Grid 14 - Dolly Sods Wilderness Area ........................................................ 38

4.2b. Results for Grid 15 - Dolly Sods Wilderness Area..................................................... 38

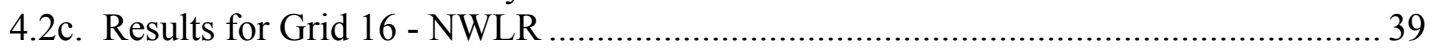

4.2d. Results for Grid 19 - Canaan Valley Institute …………………………………....... 40

4.2e. Results for Grid 20 - Canaan Valley Institute........................................................... 40

4.2f. Depth Profile Results ............................................................................................ 41 
4.2g. Results for Grid XD - Dolly Sods Wilderness Area (former Grid 3 from June 2007

Field Campaign)

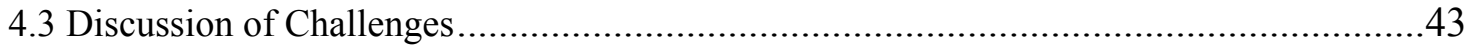

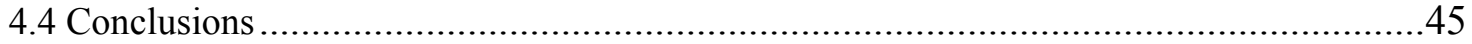

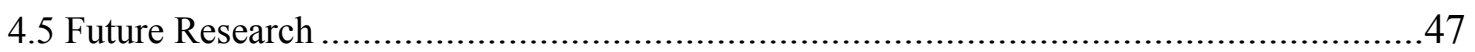

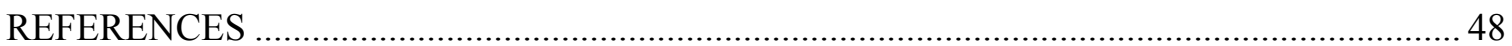

Appendix A. Standard Operating Procedure - Soil Sampling .............................................. 52

Appendix B. Standard Operating Procedure- Mechanical Grinding of Soil Samples ................... 54

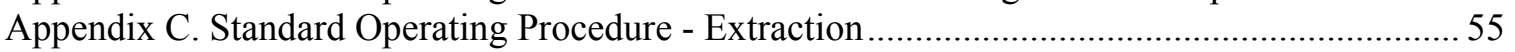

Appendix D. Representative Field Notes and Data Sheets .............................................................56

Appendix E. Representative Chromatograms from Preliminary Soil Analysis by HPLC-UV

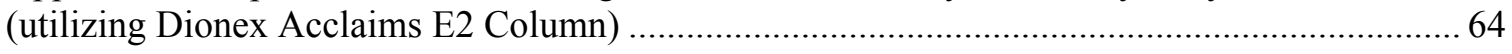




\section{LIST OF TABLES}

Table 1- Physical and Chemical Properties of TNT, RDX, and HMX............................4

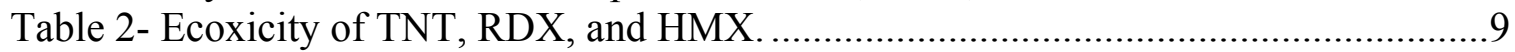

Table 3 - UXO parent compounds and known transformation products.........................11

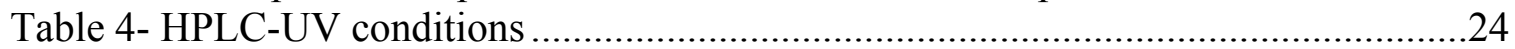

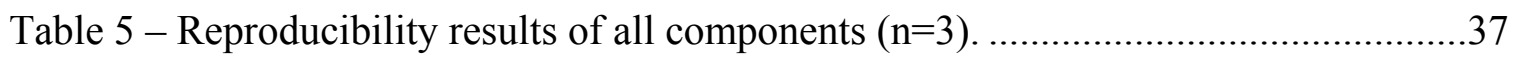

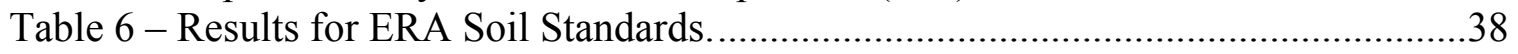

Table 7 - Results for the multi-increment sampling from Grid 15 (Grid 7, June 2007

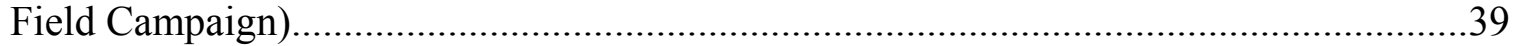

Table 8 - Results for the multi-increment and random grab samples from Grid 19........40

Table 9 - Results for multi-increment, random grab, and cored soil samples from Grid 20

Table 10 - Results for random grab samples from Site XD, Grid 3 June 2007 Field

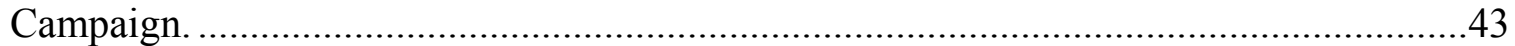

Table 11 - Summary of contaminant concentrations. .............................................. 46 


\section{LIST OF FIGURES}

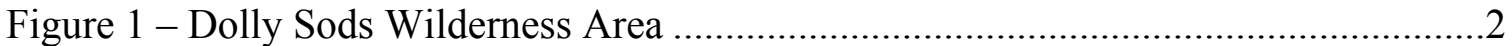

Figure 2-Classification of explosive substances based on performance and use................4

Figure 3- Structures of TNT, RDX, and HMX

Figure 4- Structures of the six isomers of trinitrotoluene ..................................................5

Figure 5- Suggested biotransformation of TNT to the main degradation products found in

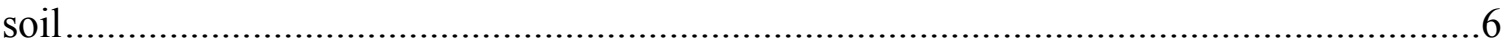

Figure 6- Biodegradation pathway of RDX under anaerobic conditions ..........................

Figure 7- Biodegradation pathway of HMX under anaerobic conditions............................

Figure 8- Examples of UXO identified in the WV Maneuver Area .................................10

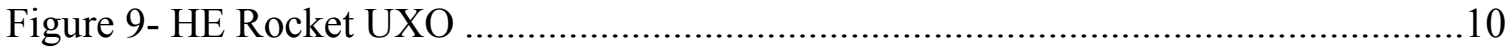

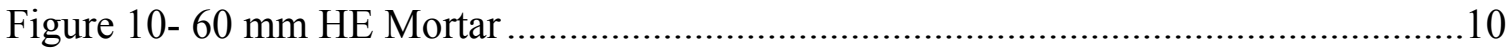

Figure 11- Contributions to error from field and laboratory sources.................................12

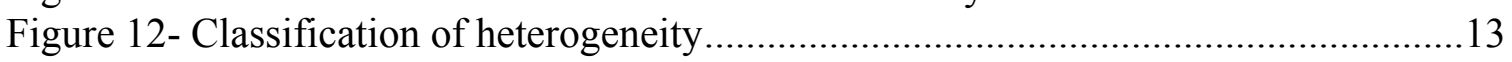

Figure 13- Topographic relief map of the Dolly Sods North Area developed by the US

Army Corps of Engineers- Huntington District...............................................................15

Figure 14 - Red Creek UXO Study Area. ..................................................................16

Figure 15 - Sampling locations within the Red Creek study Area....................................17

Figure 16 - UXO Ordnance and Safety Specialist. ........................................................18

Figure 17 - The post-processed GIS shapefile produced from the field work. .................18

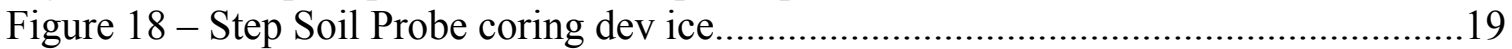

Figure 19 - CRREL designed coring device .............................................................19

Figure 20 - Schematic representation of systematic-random ..........................................20

Figure 21 - Schematic representation of the recommended decision unit for a target area in the impact area of an artillery range .......................................................................21

Figure 22- Schematic representation of sampling pattern for samples in $50 \times 50 \mathrm{~m}$ grids. 21 Figure 23- Schematic representation of a sampling pattern used for replicate analysis in

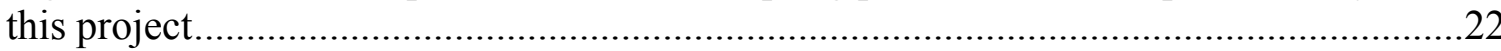

Figure 24 - Schematic of procedure used to gather multi-increment profile samples where transport and deposition of energetic materials is expected. ……………………….........22 Figure 25 - GPS image of Grid 14 (August 2007 Field Campaign) and Grid 4 (June 2007

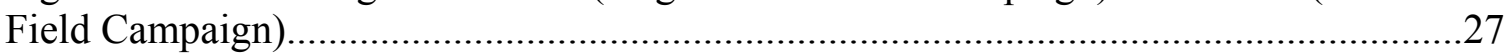
Figure 26 - Photograph of researchers staking the decision unit for Grid 14. The steep, rocky and heavily vegetated terrain presented challenges during sampling......................27 Figure 27 - GPS image of Grid 15 (August 2007 Field Campaign) and Grid 7 (June 2007

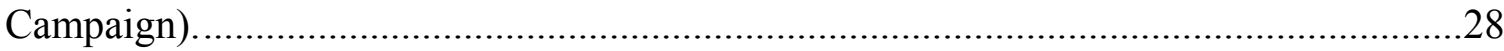
Figure 28 - Photograph of a research group member staking out the decision unit for Grid 15.

Figure 29 - Photograph showing the members of the research team collecting samples from Grid 15 using the CRREL coring devise and the step soil probe................................28

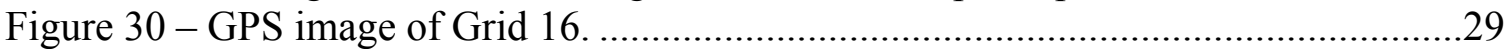
Figure 31 - Photograph showing researchers navigating the rocky and vegetated terrain to collect samples with the step soil probe. 30 
Figure 32 - Photograph showing the $2 \mathrm{~m} \times 2 \mathrm{~m}$ decision unit surrounding the crater found within Grid 16. Exposed clay-like soil and mud presented challenges during sampling and cleaning (inset).

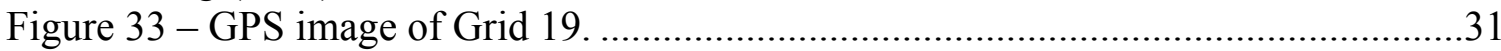

Figure 34 - Photograph showing Grid 19. The crater was nestled in the cluster of rocks

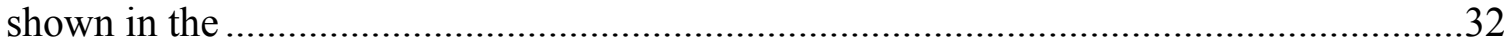

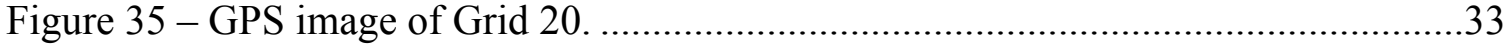

Figure 36 - Photograph showing members of the research team gathering soil samples from......

Figure 39 - GPS image of Grid 3 (June 2007 Field Campaign). Site XD was sampled where...

Figure 37 - Top-down view of depth profiling pattern used to sample the crater in Grid 20.

Figure 38 - Photograph showing white chunks of potential explosive visible on the surface of the crater in Grid 20.

Figure 40 - Photograph showing the crater in the area where a $60 \mathrm{~mm}$ mortar was found and detonated during the June 2007 Field Campaign. The area was sampled as site XD

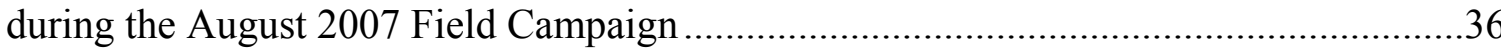
Figure 41 - Image depicting results from Grid 16: multi-increment sampling of the $10 \mathrm{x}$ $10 \mathrm{~m}$

Figure 42 - Plot of Depth vs. Normalized Concentration of RDX and HMX from Grid 20.

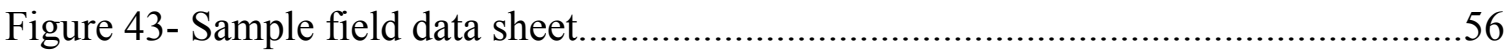

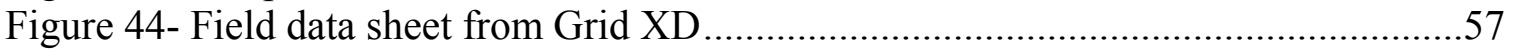

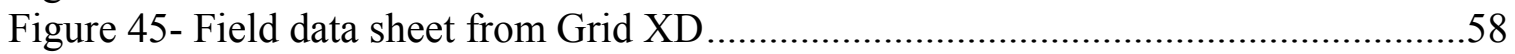

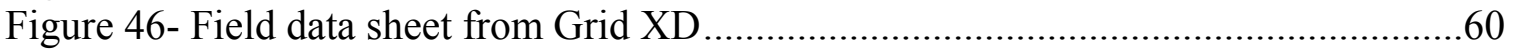

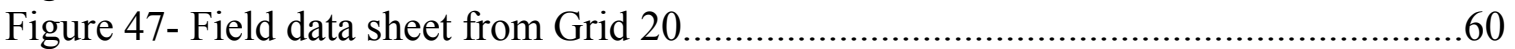

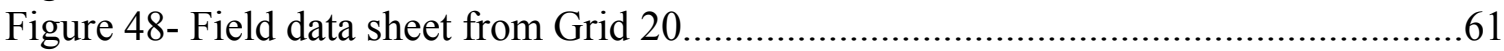

Figure 49- Field data sheet from Grid 20...........................................................62

Figure 50- Field data sheet from Grid 20 ...............................................................63

Figure 51- Representative HPLC-UV chromatogram from analysis of 500ppb calibration standard

Figure 52- Representative HPLC-UV chromatogram from analysis of diatomaceous earth64

Figure 53- Representative HPLC-UV chromatogram from analysis of blank soil...........65

Figure 54- Representative HPLC-UV chromatogram from analyis of sample

WVU_2007_14_MI_1

Figure 55- Representative HPLC-UV chromatogram from analysis of sample

WVU_2007_14_CORE_1a......

Figure 56- Representative HPLC-UV chromatogram from analysis of sample

WVU_2007_14_CORE_1b

Figure 57- Representative HPLC-UV chromatogram from analysis of sample

WVU_2007_14_CORE_1c.

Figure 58- Representative HPLC-UV chromatogram from analysis of sample

WVU_2007_15_MI_1

Figure 59- Representative HPLC-UV chromatogram from analysis of sample

WVU_2007_16_GRAB 
Figure 60- Representative HPLC-UV chromatogram from analysis of sample WVU 2007 16_MI 1

Figure 61- Representative HPLC-UV chromatogram from analysis of sample WVU_2007_16_MI_2

Figure 62- Representative HPLC-UV chromatogram from analysis of sample

WVU_2007_16b_MI

Figure 63- Representative HPLC-UV chromatogram from analysis of sample

WVU 2007 19 GRAB

Figure 64- HPL $\bar{C}-U V$ chromatogram from analysis of sample WVU_2007_19_MI (first

run in triplicate)

Figure 65- HPLC-UV chromatogram from analysis of sample WVU_2007_19_MI

(second run in triplicate)

Figure 66- HPLC-UV chromatogram from analysis of sample WVU_2007_19_MI (third

run in triplicate).

Figure 67- Representative HPLC-UV chromatogram from the analysis of sample

WVU 2007_20_GRAB

Figure 68- Representative HPLC-UV chromatogram from analysis of sample

WVU_2007_20_MI_1.

Figure 69- Representative HPLC-UV chromatogram from analysis of sample

WVU_2007_20_MI_3

Figure 70- Representative HPLC-UV chromatogram from analysis of sample

WVU_2007_20_CORE_1

Figure 71- Representative HPLC-UV chromatogram from analysis of sample

WVU_2007_XD_1

Figure 72- Representative HPLC-UV chromatogram from analysis of sample

WVU 2007 XD 2

Figure 73- Representative HPLC-UV chromatogram from analysis of sample

WVU_2007_XD_3a....

Figure 74- Representative HPLC-UV chromatogram from analysis of sample

WVU_2007_XD_3b

Figure 75- Representative HPLC-UV chromatogram from analysis of sample

WVU_2007_XD_4

Figure 76- Representative HPLC-UV chromatogram from analysis of sample

WVU_2007_20_MI_2

Figure 77- Representative HPLC-UV chromatogram from analysis of sample

WVU_2007_20_CORE_2 


\title{
LIST OF ACRONYMS
}

\author{
ADNT - Aminodinitrotoluene \\ CRREL - Cold Regions Research and Engineering Laboratory \\ DNT - Dinitrotoluene \\ DNB - Dinitrobenzene \\ EPA - Environmental Protection Agency \\ DNT - Dinitrotoluene \\ GIS - Geographic Information System \\ GPS - Global Positioning System \\ HE - High Explosive \\ HMX - Octahydro-1,3,5,7-tetranitro-1,3,5,7-tetrazocene (High Melting Explosive) \\ HPLC - High Performance Liquid Chromatography \\ MC- Munitions Constituents \\ MI - Multi-increment \\ NB - Nitrobenzene \\ NT - Nitrotoluene \\ NWLR - Canaan Valley National Wildlife Refuge \\ OE - Ordnance and Explosives \\ PTFE - Polytetraflouroethylene \\ QC - Quality Control \\ RDX - Hexahydro-1,3,5-trinitro-1,3,5-triazine (Research Developed Explosive) \\ SOP - Standard Operating Procedure \\ TNT - Trinitrotoluene \\ USACE - United States Army Corps of Engineers \\ UXO - Unexploded Ordnance \\ WVDEP - West Virginia Department of Environmental Protection \\ WVU - West Virginia University
}

\section{DEFINITIONS}

Decision Unit- estimated exposure area being sampled to determine a course of action

Composite Grab Sample- bias composite sample composed of discrete segments of soil from within the decision unit

Multi-Increment Sample- composite sample composed of multiple, random, and uniform segments of soil from within the decision unit 


\section{CHAPTER 1: INTRODUCTION}

\subsection{Overview}

Most explosive materials are toxic and, due to this toxicity, present health hazards to those who handle or are exposed to them. In the environmental field, disposal of explosives and their degradation products poses serious and potentially dangerous contamination issues. The three main explosives discussed in this report, 2,4,6-trinitrotoluene (TNT), cyclotrimethylenetrinitramine (RDX), and cyclotetramethylenetetranitramine (HMX) have all been shown to have significant and deleterious effects on humans and environments. A sizeable amount of research has been conducted to determine how best to characterize the level of explosive contamination present in exposed environments and the most desirable method of remediation. This chapter presents a review of the literature of important developments in the evaluation methods of areas exposed to explosives, specifically former munitions testing/target areas and the chemistry behind contamination by TNT, RDX, and HMX. The construction of the GIS framework, materials, and methods used in the project are discussed in Chapter 2. Chapter 3 describes the sites studied in this project. Finally, Chapter 4 presents the results of the analysis, a discussion of the results and complications, and conclusions drawn from the project.

\subsection{Background}

In 1986, Congress expanded the Comprehensive Environmental Response, Compensation, and Liability Act of 1980 to include the Superfund Amendments and Reauthorization Act of 1986 thereby providing appropriations for a "Superfund" program to finance cleanup of uncontrolled hazardous waste sites. ${ }^{1}$ Specifically, Section 211 of this amendment established the Department of Defense Environmental Restoration Program (DERP) which established a research program for military hazardous waste and the health effects of exposure to them, funding for removal of unsafe debris, and funding for implementation of the entire statute. ${ }^{2}$ Removal and remediation activities for active Department of Defense Sites are regulated by the Installation Restoration Program (IRP). Cleanup of sites that were contaminated while under the jurisdiction of the Department of Defense, but have since been transferred out of the control of the DoD, are categorized as Formerly Used Defense Sites (FUDS), and are regulated by the DERP legislation.

The Dolly Sods Wilderness Area is positioned between Canaan Valley and Seneca Rocks within the Monongahela National Forest. Figure 1 locates this area in Grant, Randolph and Tucker counties of West Virginia. The Wilderness Area is on the Allegheny Plateau, and has elevations ranging from 2,600 to 4,100 feet. The Wilderness Area consists of more than 18,500 acres and is well known for its extensive rocky plains, upland bogs and sweeping vistas. The United States Army Corps of Engineers (USACE) reports that visitors to the area range 45,000 to 76,000 annually. The remoteness, natural experience and limited human influences attract adventurous hikers, mountain bikers, anglers, hunters and berry pickers. 


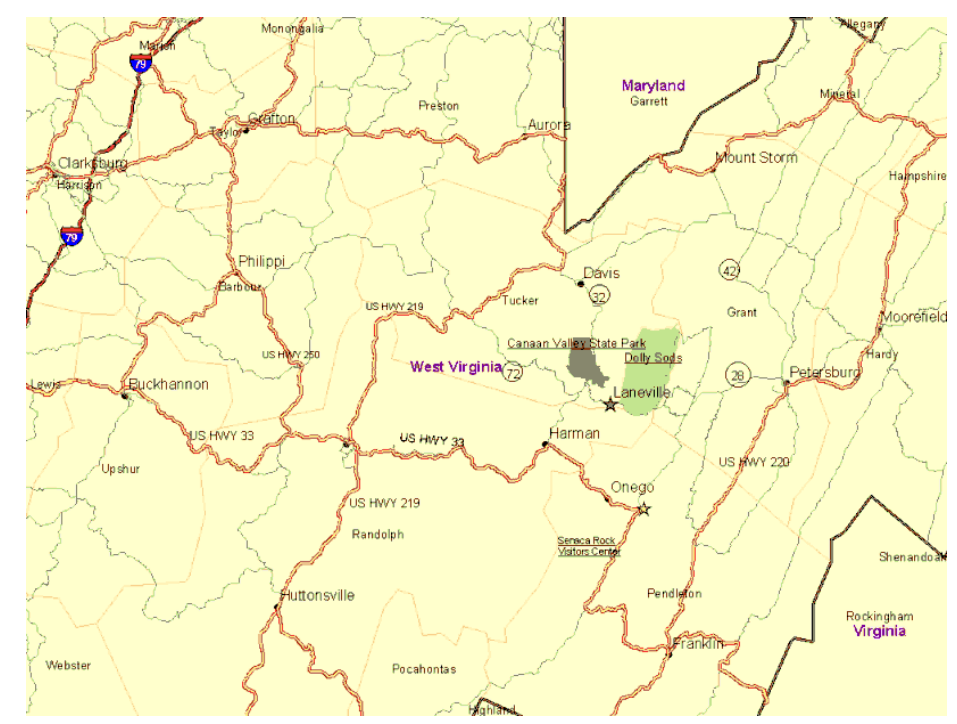

Figure 1 - Dolly Sods Wilderness Area

Between August 1943 and July 1944, the military trained troops in a 50,000 acre area which is now the Dolly Sods Wilderness area. This training was conducted by the U.S. Department of the Army and involved artillery and mortar training for more than 50,000 troops destined for World War II combat in the mountains of Italy, France, Germany, and the Pacific.

Beginning in 1992, the private lands surrounding Dolly Sods were sold by the Nature Conservancy to the United States Government for inclusion in the Wilderness Area of the National Forest. Given its use as a military training facility under the Department of Defense and its subsequent transition to a wilderness area, the area known as the West Virginia Maneuver Area, which includes the Dolly Sods Wilderness Area is classified as a FUDS site. Following this sale, the DoD delegated authority for executing ordnance and explosives $(\mathrm{OE})$ response actions to the United States Army Corps of Engineers (USACE), whose Huntington District has geographical jurisdiction over this area. The USACE performed site inspections in July 1995 and confirmed ordnance areas were documented based on verifiable historical evidence and direct witness of ordnance items. ${ }^{3}$ Ordnance removal actions in 1997 and 1998 generated the removal and disposal of 22 live and 19 inert mortar rounds, and $1151 \mathrm{lbs}$ of OE scrap which was uncovered from the top $70 \mathrm{~cm}$ ( $24 \mathrm{in}$.) of soil from over 23,000 excavations.

The USACE reports that the ordnance related risk to the public cannot be mitigated entirely at Dolly Sods. ${ }^{4}$ Current technologies, such as hand-held or air-borne magnetometers, are difficult to use at Dolly Sods due to anomalies including magnetic rock, metallic debris from logging, and railroad operations. Challenges with the regional remoteness, rough mountainous terrain, bog areas, and heavy vegetation posed unique problems which limited the capacity to locate and recover UXO. Other factors impeding remediation included the historically unknown, random, and undocumented movements of the military forces in the area. For example, documentation is lacking regarding total number and type of rounds fired, target zones, and firing positions. These problems are not unique to Dolly Sods; rather, they are common to old firing ranges across the United States and limit the ability of the USACE to undertake thorough assessment, remediation and ultimately public risk reduction. 


\subsection{History of Environmental Explosives Detection}

The toxic effects of explosives can range in severity from dizziness and hallucinations to fatal conditions such as cancer and aplastic anemia. ${ }^{5}$ In the past, explosives waste has been disposed of by burning, burial, and discharge into waterways. These disposal methods are unacceptable today due to environmental regulations restricting such release pollutants. In order to assess the extent of level of contamination in an area, it is necessary to analyze soil and groundwater for the presence of explosives and their degradation products. ${ }^{5}$ On site detection, using screening tests and/or mobile detectors is of particular interest in environmental studies as such methods could allow for early enough detection to prevent pollutants from entering groundwater systems from soils. ${ }^{5}$ A considerable research effort has been made to develop onsite detection techniques using such established methods as color screening tests, ${ }^{6}$ immunoassays and sensors, ${ }^{7-11}$ electrochemical detection, ${ }^{11,12}$ laser detection, ${ }^{13}$ ion mobility spectrometry, ${ }^{14,15}$ and canine olfactory sensing. . $^{16}$

More recently, former military munitions testing sites have become of interest in terms of assessing the levels of contamination ${ }^{17,18}$ and identifying the need for and most effective avenue of remediation. The US Army Cold Regions Research and Engineering Laboratory (CRREL) and the US Environmental Protection Agency (USEPA) have lead major efforts to develop effective techniques for sampling soils ${ }^{19,20}$ and analyzing them for explosives residues and their degradation products. ${ }^{21-25}$

\subsection{Background on Explosives Analyzed in this Project}

The UXO recovered at the sampling sites in this project consisted of TNT explosive and were detonated, or "blown-in-place," with either TNT or C-4, which contains RDX (and therefore HMX). Given this knowledge (and later the analytical findings), this project will focus mainly on the explosives of TNT, RDX, and HMX.

\section{4a. Physical and Chemical Properties of TNT, RDX, and HMX}

Explosives can be classified, based on performance and use, as primary explosive, secondary explosive, or propellants (Figure 2). Since TNT, RDX, and HMX cannot be readily detonated by heat or shock and are generally more powerful than primary explosives, they are classified as secondary explosives. Secondary explosives can only be detonated by the shock produced upon explosion of a primary explosive. ${ }^{26}$ Structures for TNT, RDX and HMX are shown in Figure 3 while physical and chemical properties are tabulated in Table 1. 


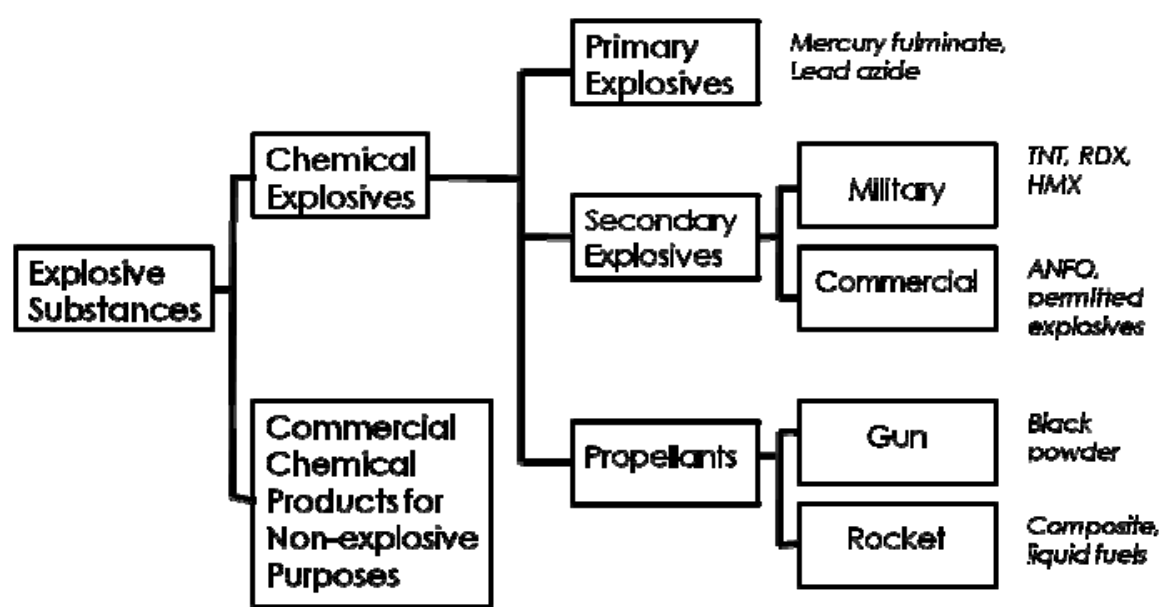

Figure 2- Classification of explosive substances based on performance and use<smiles>Cc1c([N+](=O)[O-])cc([N+](=O)[O-])cc1[N+](=O)[O-]</smiles>

TNT<smiles>O=[N+]([O-])N1CN([N+](=O)[O-])CN([N+](=O)[O-])C1</smiles>

RDX<smiles>O=[N+]([O-])N1CN([N+](=O)[O-])CN([N+](=O)[O-])CN([N+](=O)[O-])C1</smiles>

HMX

Figure 3- Structures of TNT, RDX, and HMX

Table 1- Physical and Chemical Properties of TNT, RDX, and HMX

\begin{tabular}{|c|c|c|c|}
\hline & TNT & RDX & HMX \\
\hline Molecular Weight (g/mol) & 227.13 & 222.26 & 296.16 \\
\hline Molecular Formula & $\mathrm{C}_{7} \mathrm{H}_{5} \mathrm{~N}_{3} \mathrm{O}_{6}$ & $\mathrm{C}_{3} \mathrm{H}_{6} \mathrm{~N}_{6} \mathrm{O}_{6}$ & $\mathrm{C}_{4} \mathrm{H}_{8} \mathrm{~N}_{8} \mathrm{O}_{8}$ \\
\hline Physical Appearance & $\begin{array}{c}\text { Colorless } \\
\text { crystalline solid }\end{array}$ & $\begin{array}{c}\text { White crystalline } \\
\text { solid }\end{array}$ & $\begin{array}{l}\text { Colorless/white } \\
\text { crystalline solid }\end{array}$ \\
\hline Density $\left(\mathrm{g} / \mathrm{cm}^{3}\right)$ & 1.65 & 1.83 & 1.96 \\
\hline Water Solubility (g/100g) & $.01\left(25^{\circ} \mathrm{C}\right)$ & $.006\left(25^{\circ} \mathrm{C}\right)$ & $.00066\left(20^{\circ} \mathrm{C}\right)$ \\
\hline Melting Temperature $\left({ }^{\circ} \mathrm{C}\right)$ & 80.8 & 204 & 275 \\
\hline Thermal Ignition Temperature $\left({ }^{\circ} \mathrm{C}\right)$ & 300 & 260 & 335 \\
\hline Vapor Pressure (mm Hg @ 25ㅇ) & $5.5 \times 10^{-6}$ & $4.6 \times 10^{-9}$ & $2.4 \times 10^{-8}$ \\
\hline
\end{tabular}

TNT is a widely used military explosive with a low sensitivity to impact and friction and a fairly high explosive power. Crude production of TNT results in a mixture of the symmetrical isomer $(2,4,6$-trinitrotoluene- referred to in this project as TNT) and 5 unsymmetrical isomers (Figure 4). TNT is thermally and chemically stable, has low volatility and hygroscopicity (at $30^{\circ} \mathrm{C}$ when exposed to air at $90 \%$ relative humidity it absorbs $.03 \%$ of water, ${ }^{27}$ and is compatible with other explosives. $^{5,26}$ 


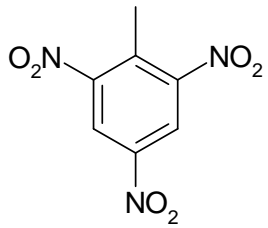

2,4,6- TNT<smiles>Cc1c([N+](=O)[O-])ccc([N+](=O)[O-])c1[N+](=O)[O-]</smiles>

2,3,6- TNT<smiles>Cc1ccc([N+](=O)[O-])c([N+](=O)[O-])c1[N+](=O)[O-]</smiles>

2,3,4- TNT<smiles>Cc1cc([N+](=O)[O-])c([N+](=O)[O-])cc1[N+](=O)[O-]</smiles>

2,4,5- TNT<smiles>Cc1cc([N+](=O)[O-])cc([N+](=O)[O-])c1[N+](=O)[O-]</smiles>

2,3,5- TNT<smiles>Cc1cc([N+](=O)[O-])c([N+](=O)[O-])c([N+](=O)[O-])c1</smiles>

3,4,5- TNT

Figure 4- Structures of the six isomers of trinitrotoluene

Cyclotrimethylenetrinitramine (more commonly known as Royal Demolition Explosive or RDX) is also an important military explosive. Pure RDX is very sensitive to impact and friction and is desensitized by coating the crystals with wax, oils, or grease. ${ }^{26}$ Embedding the crystals in a polymeric matrix to form polymer bonded explosives (PBX) makes the resulting compound less sensitive to accidental initiation $^{26}$ RDX is not as stable as TNT, although it is considered highly stable, and has a greater explosive power than TNT. ${ }^{5}$ The manufacturing of RDX results in the final product containing trace amounts to $6-9 \% \mathrm{HMX}^{5}$

Cyclotetramethylenetetranitramine (more commonly known as HMX) is a component in some solid rocket fuels and has also been used as a burster charge for artillery shells. ${ }^{5}$ HMX is nonhygroscopic and essentially insoluble in water. HMX has a higher ignition temperature and is more chemically stable than RDX; however, the explosive power of HMX is somewhat less than RDX . ${ }^{26}$

\section{4b. Degradation of TNT, RDX, and HMX}

Biodegradation of TNT has been shown to occur aerobically ${ }^{28}$ and anaerobically. ${ }^{29}$ The main degradation products of TNT found in contaminated soils are 2-amino-4,6dinitrotoluene, 4-amino-2,6-dinitrotoluene, 2,4-diamino-6-nitrotoluene, and 2,6-diamino-4nitrotoluene . ${ }^{5}$ A suggested biotransformation of TNT to these degradation products through intermediate amines (2-OHA and 4-OHA, which are 2-hydroxyamino-4,6dinitortoluene and 4hydroxyamino-2,6-dinitrotoluene, respectively) is shown in Figure 5. 


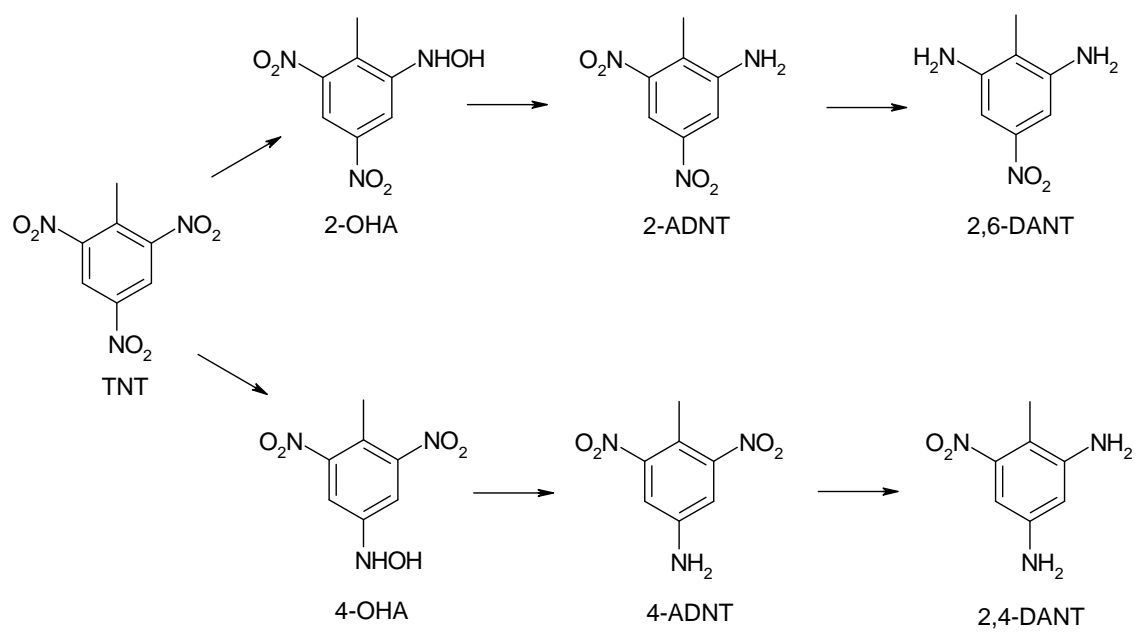

Figure 5- Suggested biotransformation of TNT to the main degradation products found in soil

Many unsuccessful attempts have been made to degrade RDX aerobically, but some more recent attempts have had greater success and show promise with species such as Rhodococcus rhodochrous and the PB1 strain of Stenotrophomonas maltophilia ${ }^{30,31}$ Species such as Enterobacteriaceae have been shown to degrade RDX and HMX anaerobically. ${ }^{32,33}$ Anaerobic biodegradation of RDX yields hexahydro-1-nitroso-3,5-dinitro-1,3,5-triazine (MNX), hexahydro-1,3-dinitroso-5-nitro-1,3,5-triazine (DNX), and hexahydro-1,3,5-trinitroso-1,3,5triazine (TNX) as degradation products. ${ }^{5}$ A scheme for the anaerobic biodegradation of RDX, proceeding through successive reduction of the nitro groups until the ring destabilizes and fragments, is shown in Figure $6 .{ }^{34}$ The non-cyclic products are formed from continued reduction and rearrangements of the fragments. ${ }^{5}$ 


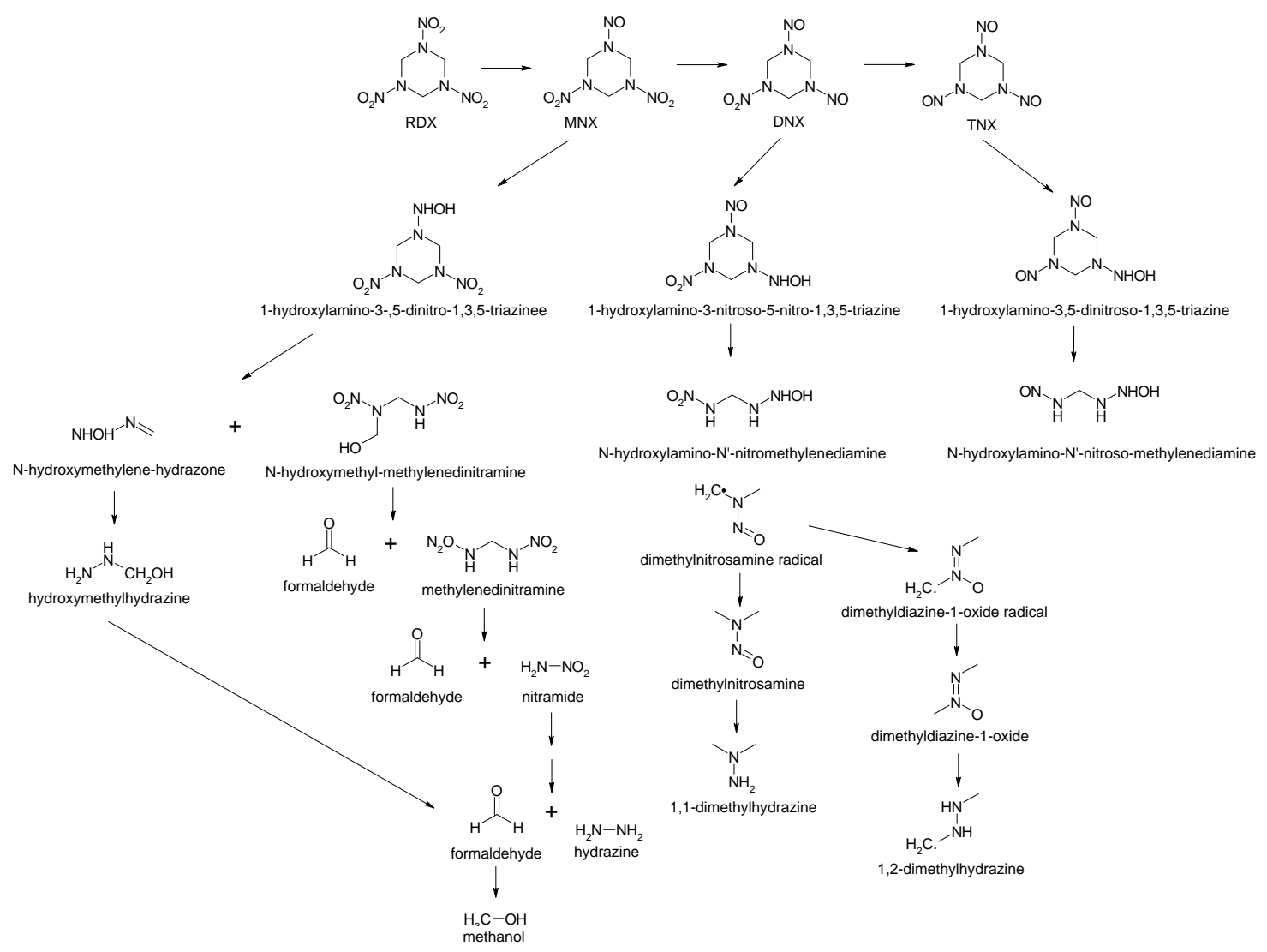

Figure 6- Biodegradation pathway of RDX under anaerobic conditions

Due to their structural similarity, HMX is thought to biodegrade in a similar fashion to RDX. ${ }^{35}$ Figure 7 shows the anaerobic degradation pathway for HMX, yielding mono-, di-, tri-, and tetranitroso intermediates of HMX via successive reduction of the nitro groups. ${ }^{35}$ Spanggord, et.al. propose that further anaerobic metabolism of HMX will yield further reductive transformation of the nitroso derivatives. ${ }^{35}$

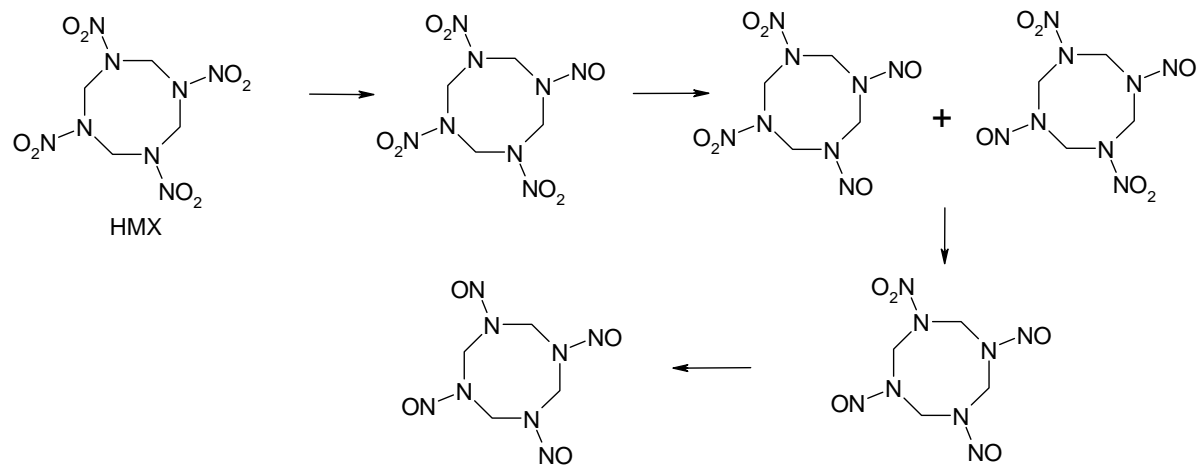

Figure 7- Biodegradation pathway of HMX under anaerobic conditions

\section{4c. Human Toxicity of TNT, RDX, and HMX}

TNT is absorbed into the human body through three channels: skin adsorption, inhalation, and absorption by the gastrointestinal tract. ${ }^{27}$ Skin is the main absorption channel, particularly 
in the presence of oily skin and sweaty, greasy hands. ${ }^{27}$ TNT poisoning presents itself in a variety of symptoms including gastritis and cyanosis. More serious levels of TNT poisoning can result in toxic jaundice and aplastic anemia, both of which can be fatal. Treatment of TNT toxicity begins with removal of all contact with TNT (including the removal of clothing and trimming/cleaning of the fingernails) and, in more advanced cases, can include artificial oxygen inhalation (cyanosis), infusion of glucose and large intake of carbohydrates (TNT jaundice), and even blood transfusions (aplastic anemia). ${ }^{27}$

RDX poisoning manifests itself in confusion, hyperirritability, involuntary myoclonic contractions of the extremities, single or multiple generalized seizures, and prolonged postictal mental confusion and amnesia. ${ }^{27} \mathrm{RDX}$ is also a possible Class $\mathrm{C}$ carcinogen. ${ }^{30}$ Most victims of poisoning exhibited symptoms within a half hour to several hours after exposure and were free of symptoms from 48 hours to 2 months after exposure ceased. Treatment of RDX poisoning includes gastric lavage, seizure control with anticonvulsants (such as barbiturates), maintenance of normal fluid and electrolyte balance, and hourly monitoring of urine to detect kidney failure at its onset . 27

HMX and RDX have chemical similarity, and therefore it is assumed they have similar toxic and environmental effects. ${ }^{27}$ Very little is known about the human toxicity of HMX, but clinical signs of acute toxicity in animals (fed doses of HMX) included clonic convulsions and spasms, ataxia, and other central nervous effects. ${ }^{5}$

Given the aforementioned potential risks to the environment and human health (and even fatal effects), exposure to these components should be avoided. Therefore, to insure the safety of the public and the environment associated with the Dolly Sods Wilderness Area, efforts are being made to properly dispose of UXO in the area and assess the level of contamination remaining.

\section{4d. Ecological Toxicity of TNT, RDX, and HMX}

TNT, RDX, and HMX have been shown to have lethal effects on aquatic life. ${ }^{27}$ According to the American Society for Testing and Materials (ASTM), freshwater fishes face more toxic effects from nitroaromatic compounds, with the exception of $2 \mathrm{~A} 46 \mathrm{DNT}$, with $\mathrm{LC}_{50}$ (concentration of toxicant where $50 \%$ of the test organisms die) ranging from $0.4-32 \mathrm{mg} / \mathrm{L}$ than do freshwater invertebrates $\left(\mathrm{EC}_{50}\right.$ ranging from $\left.3-100 \mathrm{mg} / \mathrm{L}\right){ }^{36}$ The most sensitive test, species with $\mathrm{LC}_{50}$ values ranging from 0.43 to $6.4 \mathrm{mg} / \mathrm{L}$ for TNT, RDX, and HMX, was the rainbow trout. These compounds produce negative effects on reproductive endpoints in terrestrial mammals at doses $>1 \mathrm{mg} / \mathrm{kg} /$ day. According to ASTMs findings, limited data indicate that nitroaromatics are not toxic to terrestrial plants with low observed effect concentrations (LOECs) ranging from $25-100 \mu \mathrm{g} / \mathrm{g}$ in soil) and soil invertebrates (LOEC of $200 \mu \mathrm{g} / \mathrm{g}$ ).

Sunahara et. al. evaluated the ecotoxicity of TNT, RDX, and HMX (among other energetic compounds) by coupling the extraction method in EPA 8330 with aquatic based toxicity tests (Microtox- 15 min test on V. fischeri and 96 hour S.capricornutum growth inhibition test). ${ }^{37}$ The results of these tests are summarized in Table 2 . The Microtox assay showed TNT to be the most toxic to the bacterial species with an average $\mathrm{IC}_{50}$ (concentration of toxicant required to decrease the bacterial bioluminescence by $50 \%$ ) of $4.2 \mu \mathrm{M}$ and that its effect on bioluminescence was concentration dependent. RDX was less toxic, with an $\mathrm{IC}_{50}$ of $>181 \mu \mathrm{M}$ 
and HMX was not toxic (up to its limit water solubility). The results of the $96 \mathrm{~h}$ growth inhibition test show the same progression of TNT, RDX, and HMX regarding the phytotoxic effects of these compounds on the freshwater unicellular green algae, S. capricornutum. TNT was found to have an $\mathrm{EC}_{50}$ value (concentration of toxicant required for $50 \%$ inhibition of algal growth) of $3.2 \mu \mathrm{M}$ while RDX was found to reduce algal growth by $40 \%$ at its maximal water solubility. HMX was not found to be toxic at its aqueous solubility limit.

Table 2- Ecoxicity of TNT, RDX, and HMX.

\begin{tabular}{|l|c|c|}
\cline { 2 - 3 } \multicolumn{1}{c|}{} & $\mathbf{I C}_{\mathbf{5 0}}(\boldsymbol{\mu M})$ & $\mathbf{E C}_{\mathbf{5 0}}(\boldsymbol{\mu M})$ \\
\hline TNT & 4.2 & 3.2 \\
\hline HMX & $>181^{*}$ & $>181^{*}$ \\
\hline
\end{tabular}

based on maximal water solubility

\subsection{Dolly Sods Project}

This project focused on characterization and investigation of the environmental contamination resulting from military ordnance existing within areas of the West Virginia Maneuver Area, including the Dolly Sods Wilderness Area - North, Canaan Valley National Wildlife Refuge, and private land holdings in Canaan Valley, West Virginia. Two field campaigns (June and August 2007) were carried out in these regions to retrieve soils for analysis. Examples of the ordnance and UXO identified at the WV Maneuver Area are illustrated in Figures 8 - 10. Figure 8 illustrates the High Explosive (HE), Illumination, Screening, and Practice Rifle Grenades. Figure 9 illustrates the HE Rocket UXO, several of which were found and blown-in-place at the Canaan Valley Institute site. At the Fisher Spring area two types of mortars were used. Figure 10 illustrates the $60 \mathrm{~mm}$ HE mortar. A mortar of this type was uncovered on the June 2007 field study and was later blown-in-place.

Three departments of West Virginia University (Water Research Institute, Department of Chemistry, and Division of Plant and Soil Sciences) performed this work in collaboration with the USACE Huntington District and the WVDEP Division of Land and Restoration. The goal of this research was to characterize the unexploded ordnance in the soils within sections of the West Virginia Maneuvers Area by investigating the use of Multi-Increment and Composite Grab field sampling techniques for contaminant characterization capability within the eastern hardwood forest and mountainous region of the Dolly Sods and Canaan Valley. The research consisted of five discrete parts: i) Literature review of existing site data, and training on munitions detection and sampling, ii) Development of GIS framework, iii) Field characterization sampling, iv) Development of analytical methods, and v) Soil chemical characterization. Details of the soils characterization fall outside the scope of this thesis, but are thoroughly discussed in the report submitted to the US Army Corps of Engineers. 


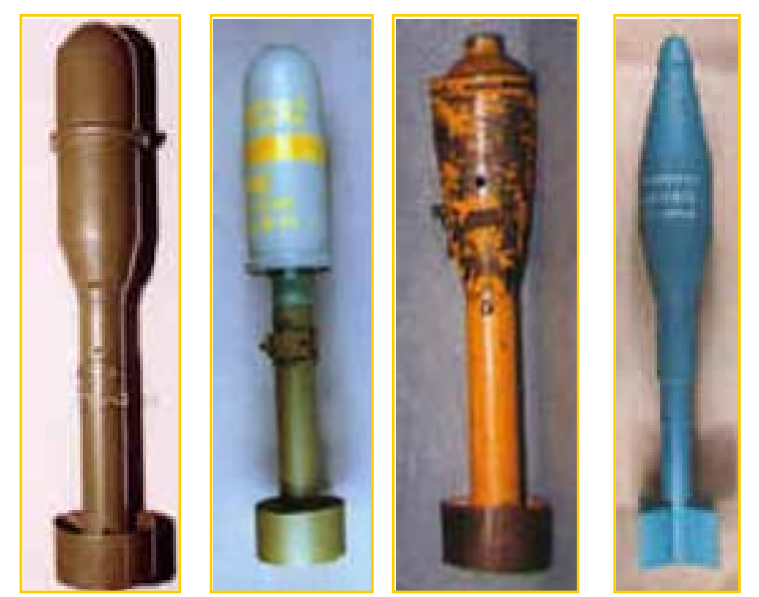

Figure 8- Examples of UXO identified in the WV Maneuver Area

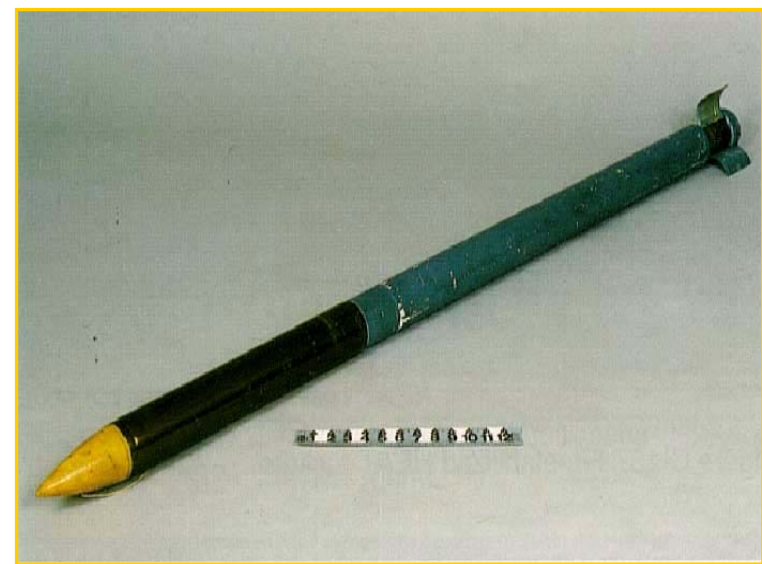

Figure 9- HE Rocket UXO

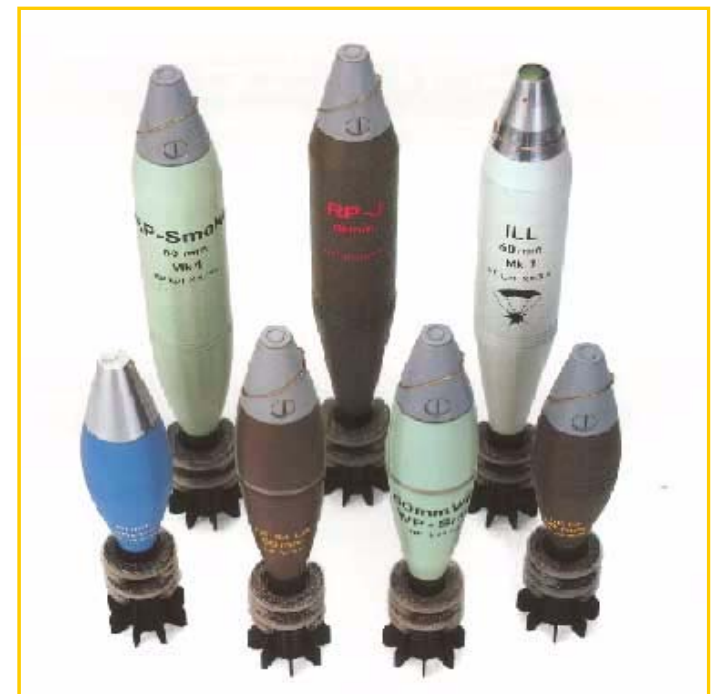

Figure 10- $60 \mathrm{~mm}$ HE Mortar

Information on past military maneuvers and recent UXO removal activities were studied in order to define the expected contaminant of concern, age, and physical state. The specific contaminants of concern are presented in Table 3. All of these compounds are either used in the manufacture of explosives or propellants, are impurities in their manufacture, or they are the degradation products of compounds used for that purpose. 
Table 3 - UXO parent compounds and known transformation products.

\begin{tabular}{llll}
\hline No. & Compound & Abbreviation & Formula \\
\hline 1 & 2,4,6-trinitrotoluene & TNT & $\mathrm{C}_{7} \mathrm{H}_{5} \mathrm{~N}_{3} \mathrm{O}_{6}$ \\
2 & hexahydro-1,3,5-trinitro-1,3,5-triazine & RDX & $\mathrm{C}_{3} \mathrm{H}_{6} \mathrm{~N}_{6} \mathrm{O}_{6}$ \\
3 & octahydro-1,3,5,7-tetranitro-1,3,5,7-tetrazocine & $\mathrm{HMX}$ & $\mathrm{C}_{4} \mathrm{H}_{8} \mathrm{~N}_{8} \mathrm{O}_{8}$ \\
4 & 1,3,5-trinitrobenzene & TNB & $\mathrm{C}_{6} \mathrm{H}_{3} \mathrm{~N}_{3} \mathrm{O}_{6}$ \\
5 & 1,3-dinitrobenzene & DNB & $\mathrm{C}_{6} \mathrm{H}_{4} \mathrm{~N}_{2} \mathrm{O}_{4}$ \\
6 & 2-amino-4,6-dinitrotoluene & $2 \mathrm{~A}-\mathrm{DNT}$ & $\mathrm{C}_{7} \mathrm{H}_{7} \mathrm{~N}_{3} 0_{4}$ \\
7 & 4-amino-2,6-dinitrotoluene & 4 -DNT & $\mathrm{C}_{7} \mathrm{H}_{7} \mathrm{~N}_{3} \mathrm{O}_{4}$ \\
8 & 2,6-diamino-4-nitrotoluene & $2,6-D A N T$ & $\mathrm{C}_{7} \mathrm{H}_{9} \mathrm{~N}_{3} \mathrm{O}_{2}$ \\
9 & 2-hydroxylamino-4,6-dinitrotoluene & $2 \mathrm{HA-DNT}$ & $\mathrm{C}_{7} \mathrm{H}_{7} \mathrm{~N}_{3} \mathrm{O}_{5}$ \\
10 & 4-hydroxylamino-2,6-dinitrotoluene & $4 \mathrm{HA-DNT}$ & $\mathrm{C}_{7} \mathrm{H}_{7} \mathrm{~N}_{3} \mathrm{O}_{5}$ \\
11 & 2,4-diamino-6-nitrotoluene & $2,4-D A N T$ & $\mathrm{C}_{7} \mathrm{H}_{9} \mathrm{~N}_{3} \mathrm{O}_{5}$ \\
12 & 2,6-dinitrotoluene & $2,6-$-DNT & $\mathrm{C}_{7} \mathrm{H}_{9} \mathrm{~N}_{3} \mathrm{O}_{5}$ \\
13 & 2,4-dinitrotoluene & $2,4-D N T$ & $\mathrm{C}_{7} \mathrm{H}_{9} \mathrm{~N}_{3} \mathrm{O}_{5}$ \\
14 & 3,5-dinitroaniline & 3,5-DNA & $\mathrm{C}_{6} \mathrm{H}_{5} \mathrm{~N}_{3} \mathrm{O}_{5}$ \\
\hline
\end{tabular}

\subsection{Statement of Problem}

In contrast to other common environmental contaminants, such as trichloroethylene (TCE), sampling for particulates in soil presents some challenges. Since particles are not distributed as uniformly throughout soils as liquids are, sampling must be done with care to insure recovered samples accurately estimate the level of contamination in the area being evaluated.

Of primary concern in all environmental analyses is the representative nature of collected samples. Since the entire site of interest cannot be collected and brought to the lab for analysis, the samples collected from the site must provide an accurate estimation of the level of contamination present at the site. Unrepresentative samples contribute to the uncertainty of analytical results. Since sampling errors and analytical errors occur independently of each other, sampling errors cannot be accounted for by laboratory blanks or control samples and most often require correction via resampling and analysis. ${ }^{38}$ The USEPA published a substantial summary of soil sampling techniques and strategies ${ }^{39}$ in which a well supported argument is made for the importance of a solid sampling plan. Figure 11 illustrates contributions to overall error from the field and laboratory. 
Figure 11- Contributions to error from field and laboratory sources

Sampling error can be attributed to heterogeneity, which can be divided into compositional and distributional sub-types. Compositional heterogeneity, or constitutional heterogeneity, is a property of the analyte under consideration and consists of the differences in composition of individual particles that make up the population as a whole. ${ }^{40}$ Distributional heterogeneity depends on compositional heterogeneity and accounts for the distribution of the anaylte within the volume occupied by the contaminated area. ${ }^{40}$ Given the intrinsic nature of compositional heterogeneity, this property cannot be altered without mechanical processing (such as grinding and/or pulverization), whereas distributional heterogeneity can be either diminished by mixing or increased by promoting segregation of the analytes. ${ }^{40}$ In the field, a well devised sampling plan can account for compositional heterogeneity by collecting an adequate sample mass.

Distributional heterogeneity can be accounted for by collecting the sample mass in many random increments. Fundamental error results from compositional heterogeneity and represents the minimum sampling error generated if concentration is a function of particle size (equation $1^{39}$, where FE is fundamental error, $\mathrm{d}$ is the largest analyte particle size, and $\mathrm{m}_{\mathrm{s}}$ is the mass of the sample). Grouping and segregation error results from distributional heterogeneity and is inversely proportional to the number of individual increments used to build the sample (or sub sample). Therefore, this factor can be reduced by collecting many random increments to form a sample. ${ }^{39}$ These concepts are represented graphically in Figure 12.

$$
F E^{2}=\frac{20 d^{3}}{m_{s}} \quad(\text { equation } 1)
$$




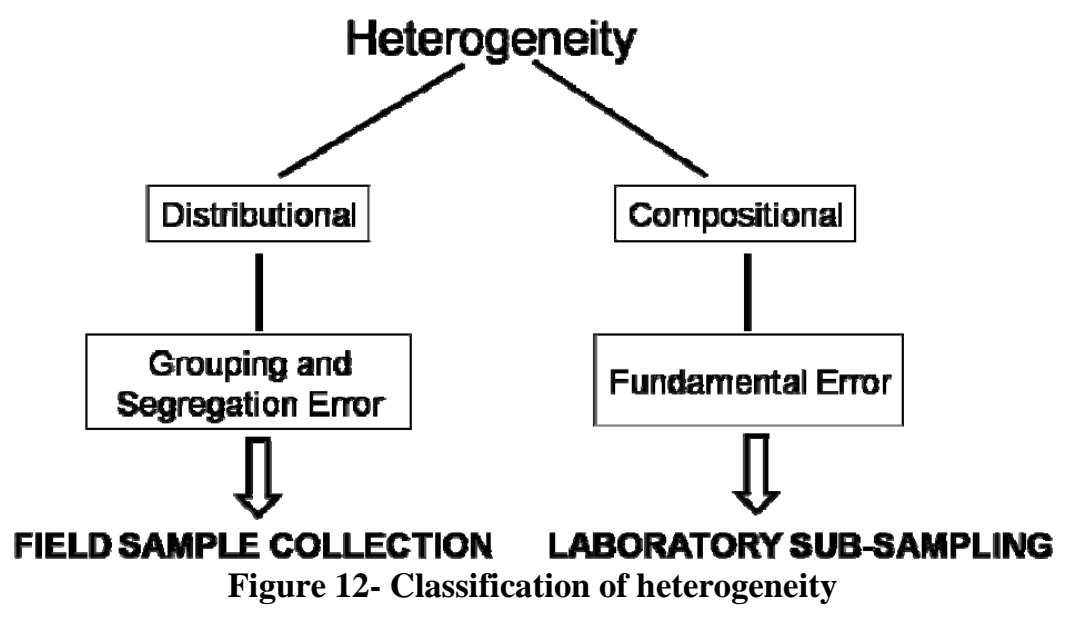

CRREL has put forth a major research effort to establish how best to sample military training ranges for energetic compounds. ${ }^{41-43}$ The work from CRREL, along with guidance from EPA publications ${ }^{39}$ and methods provides a foundation on which to build any soil analysis project; however, even with such solid science behind the construction of a sampling plan, each site introduces unique constraints and obstacles.

The challenges faced in this project will be discussed in detail in Chapter 4 . 


\section{CHAPTER 2: MATERIALS AND METHODS}

\subsection{Introduction}

The information presented in this section details the materials and methods utilized during field work conducted in June and August 2007. Two field visits were undertaken to investigate possible environmental contamination existing within areas of the West Virginia Maneuver Area. The work presented in the following sections will focus on the field work and sample analysis during the August 2007 campaign.

An initial study into the characterization of energetic particles in soil within the Dolly Sods Wilderness area, WV was carried out in June 2007. Prior to developing a sampling procedure for the study a literature search of current sampling methods was undertaken. Of the methods reviewed a SOP produced by the US EPA Environmental Response Team (SOP 2012) was selected as a basis for development of a study specific SOP. The SOP 2012 method was modified to reflect the number and type of personnel and the budget available.

The sampling SOP (Appendix A) discussed the removal of soil samples from selected areas where known UXO detonations had occurred and as such included adequate safety precautions. The SOP described collection of grab samples from marked grid areas surrounding the UXO detonation site. Procedures for individual, discrete, grab samples (see below) as well as composite grab samples were outlined.

Due to heavy vegetation within the wilderness area and the lack of effective sampling tools the SOP had to be further modified in the field in order to collect sufficient sample amounts. The approach taken was loosely based on the grid system. Grid areas were chosen based on GPS coordinates recorded for previously discovered UXO and on visual observations of the area (e.g. crater like features). If possible a composite grab sample of debris was collected and the remainder removed. Soil samples were collected from within marked grid areas using a $15.2 \mathrm{~cm}$ (6 in.) hand corer. Sample depth varied from a minimum of $2.5 \mathrm{~cm}$ (1 in.) to a maximum of $15.2 \mathrm{~cm}$ ( 6 in.). Samples collected from within the grid were combined producing a composite grab sample. Samples were stored in glass and plastic containers prior to laboratory analysis. Inlaboratory sample analysis was then carried out following US EPA Method 8330.

The second field trip conducted in August 2007 utilized a new sampling strategy outlined in EPA Method 8330b and demonstrated by CRREL in August 2007. As will be shown in the sections that follow, the sample data produced during this campaign provided a reliable and representative characterization of explosive residue contaminants in the areas studied.

\subsection{Development of GIS Framework}

Spatial UXO data was obtained from the USACE Huntington, and was integrated with existing regional data in our GIS framework (Figure 13). Existing data allowed us to locate historic military maneuver areas and previously discovered UXO locations. Location data was primarily related to the 1997 - 1998 USACE removal activities in the Dolly Sods Wilderness Area and Dolly Sods North Area. 


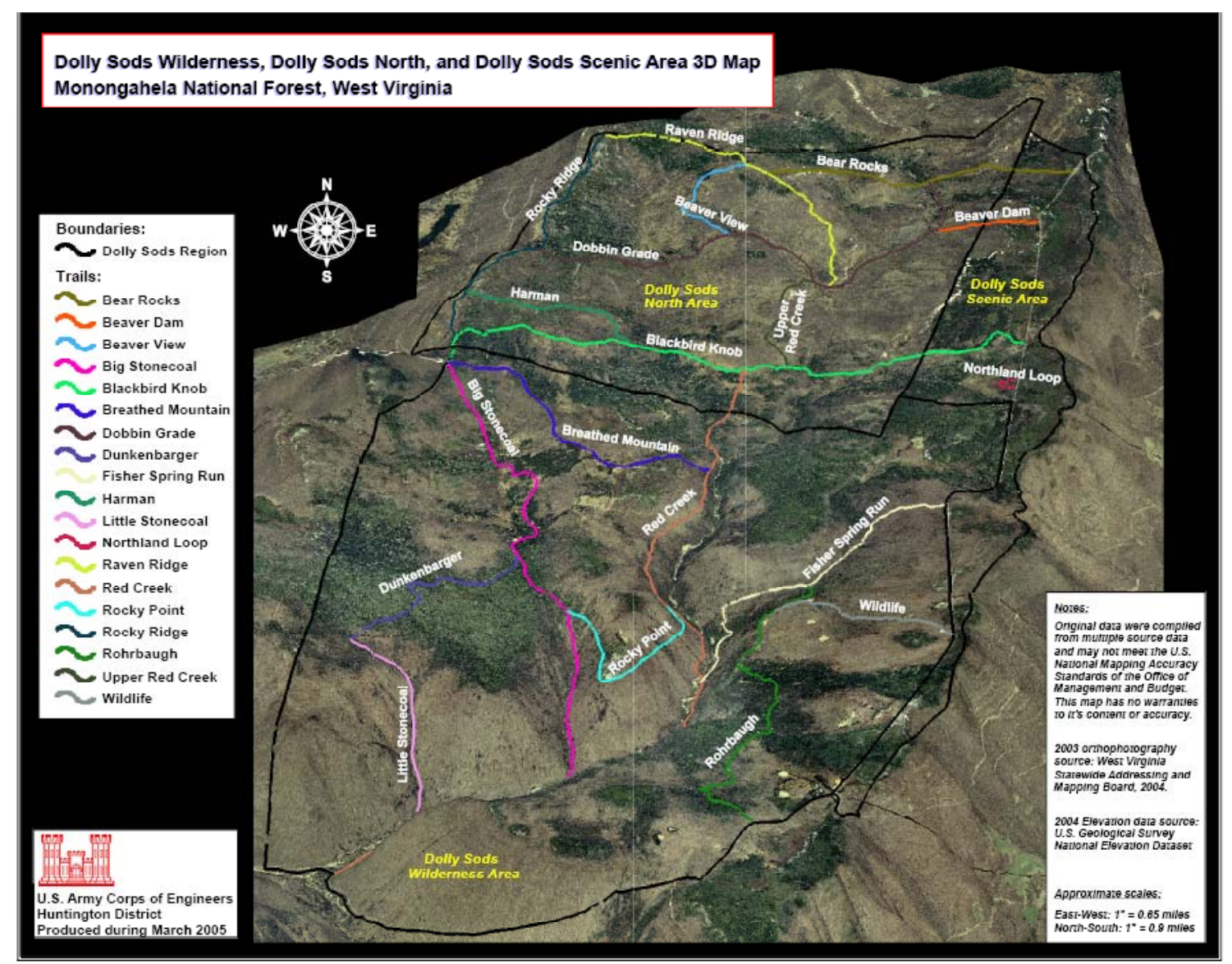

Figure 13- Topographic relief map of the Dolly Sods North Area developed by the US Army Corps of Engineers- Huntington District

The spatial information identifying previous UXO locations in the WV Maneuver Area was used as the basis for locating our study area. The majority of UXO in the Dolly Sods North Area was located along Red Creek. Our primary study region (Figure 13) encompassed the portion of the Red Creek watershed between Fisher Spring Run and Big Stonecoal, where the concentration of UXO removed during the 1997-1998 removal activities was highest. During this removal project, UXO was identified and detonated in at least 14 locations along trails in this study region. 


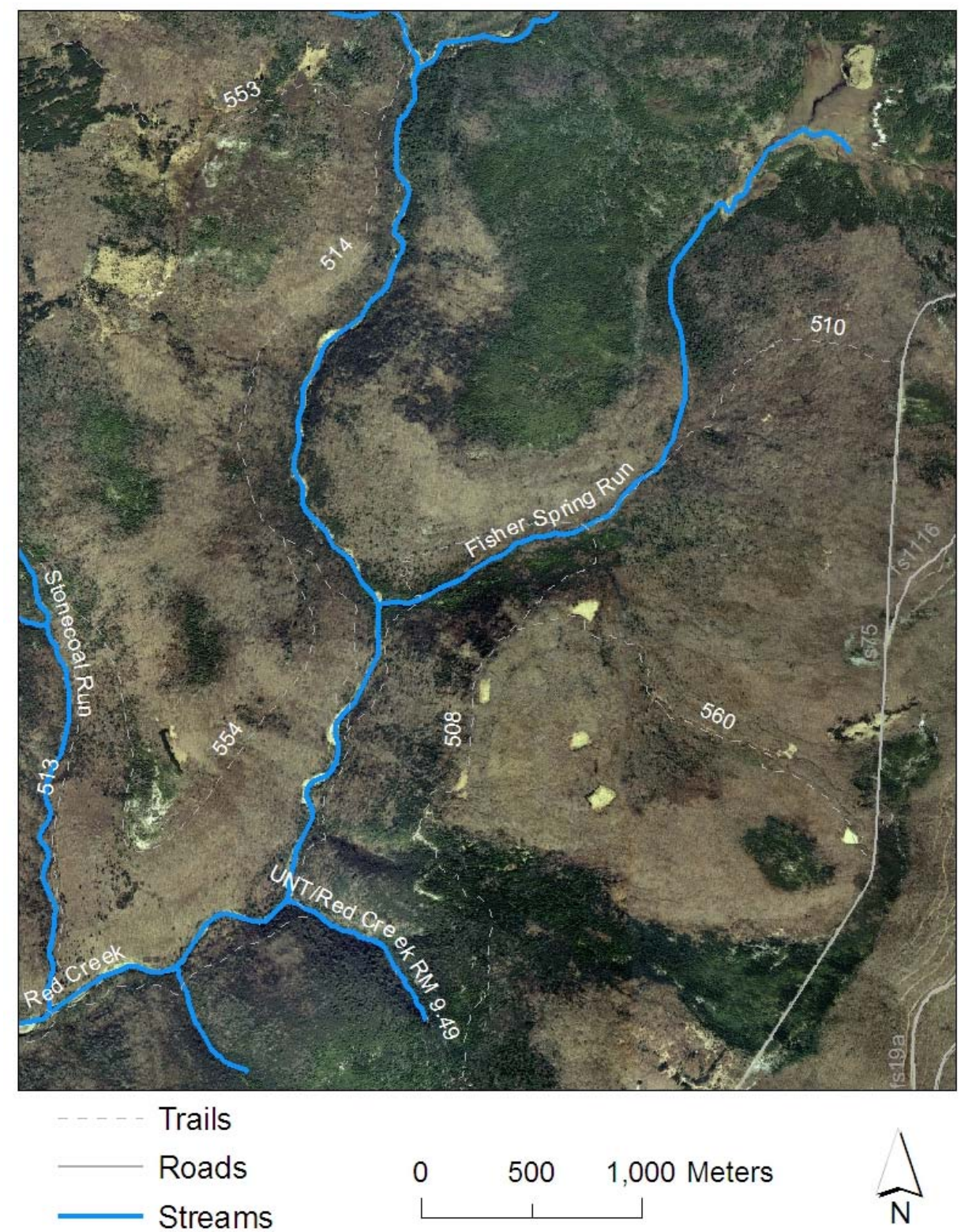

Figure 14 - Red Creek UXO Study Area.

Within our study area, candidate field sampling locations were evaluated based on UXO density, UXO type, site accessibility, and terrain type. Based on these criteria, three general sampling locations were identified: Bear Rocks, Blackbird Knob, and Breathed Mountain (Figure 14).

The shapefiles identifying previously discovered UXO were uploaded into a Global Positioning System unit (Trimble GPS Pathfinder ProXH receiver with Ranger handheld) for field coordinate location. With an external Hurricane antennae, the receiver provided sub-foot accuracy after post-processing. This allowed the field crew to locate the UXO sites and investigate the remaining contamination. The majority of the UXO sites along trails 520, 514, and 510 were investigated for signs of blow-in-place craters for soil sampling (Figure 15). 

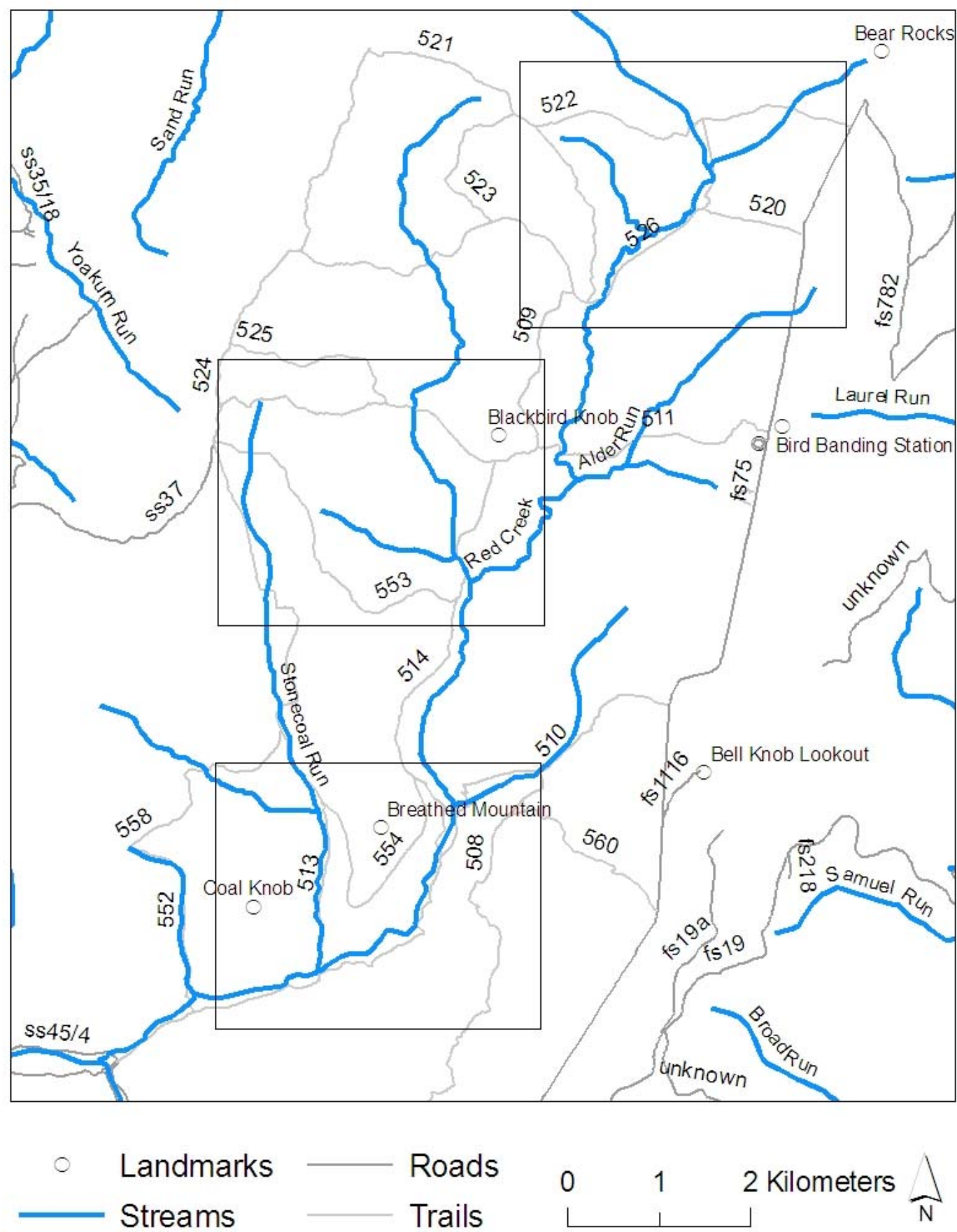

Figure 15 - Sampling locations within the Red Creek study Area.

The location of UXO sites was managed by a UXO Ordnance \& Explosives Safety Specialist from the Army Corps of Engineers, Engineering and Support Center, Huntsville, AL. The Safety Specialist oversaw all field operations and led the hiking excursions. A Schonstedt (Kearneysville, WV) metal detector was used for field screening. The Safety Specialist and GPS operator proceeded ahead of the field crew in order to locate the UXO positions. After the area 


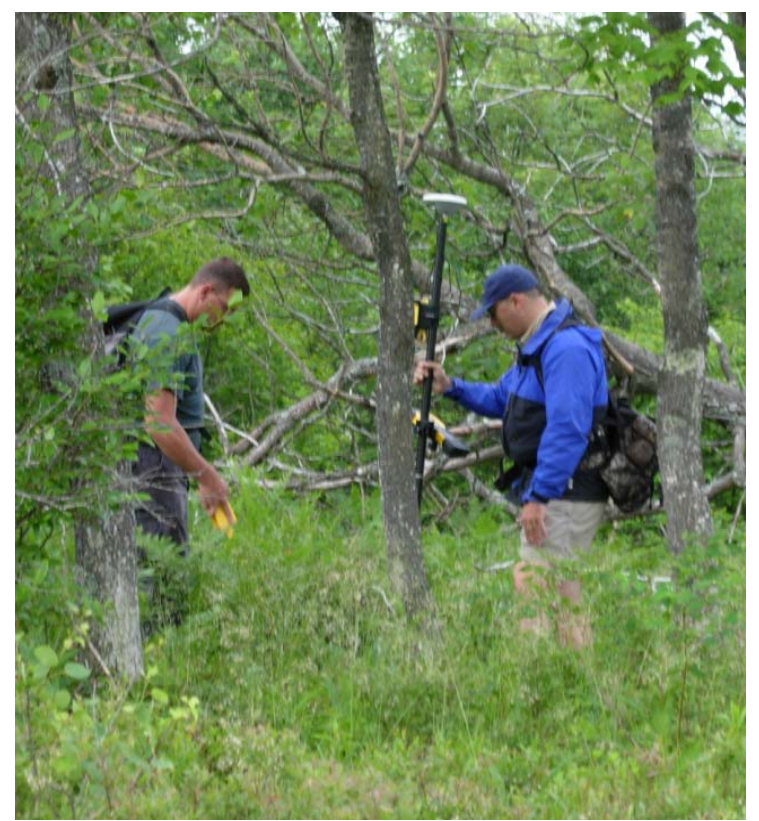

Figure 16 - UXO Ordnance and Safety Specialist.

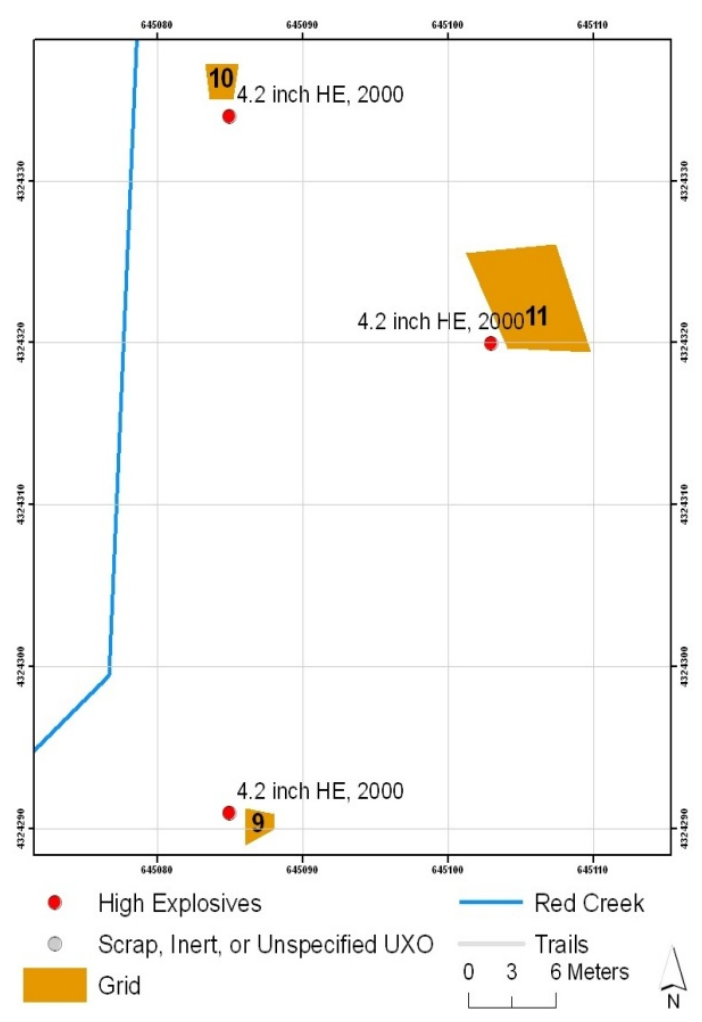

was checked, a set of flags or safety ribbon was set as a cleared perimeter prior to allowing the students to advance and begin soil characterization (Figure 16).

The candidate UXO sites with visible craters (as identified by the Safety Specialist) were mapped using the GPS system. After the crater was mapped with the GPS system, the data was post-processed using Trimble (Sunnyvale, CA) GPS Pathfinder Office software. Using the software, we identified reference base stations surrounding our site, and used information from these sites to determine the degree of error in our field coordinates. This post-processing yielded spatial data with sub-foot accuracy.

Figure 17 illustrates the post-processed GIS shapefile produced from the field work. The grid area is the cleared boundary perimeter where the UXO crater was located. The UXO point shapefile identifies the USACE GPS locations. These locations were originally obtained by the USACE using older, hand-held units. The proximity of the Corps data to the WVU data indicates excellent field verification of the UXO coordinates.

In some cases, our coordinates for fieldidentified craters did not align with the grid shapefile. Although the grids were postprocessed, the crater coordinates were simply recorded in the field. The grids should therefore be regarded as the most accurate files.

Figure 17 - The post-processed GIS shapefile produced from the field work. 


\subsection{Materials}

All composite grab samples were gathered using a stainless steel shovel.

Multi-increment samples were gathered, where possible, using a device designed by CRREL (Hanover, VT). This coring device (Figure 19) took samples to a depth of $5.1 \mathrm{~cm}(2 \mathrm{in}$.) with a diameter of $3.2 \mathrm{~cm}$ (1.25 in.). In areas where the CRREL coring device could not be used, a step soil probe (Figure 18) was used instead. This device took samples to a depth of $25.4 \mathrm{~cm}$ (10 in.) with a diameter of $1.90 \mathrm{~cm}(0.75 \mathrm{in}$.$) .$

All depth profile samples were gathered using the step soil probe.

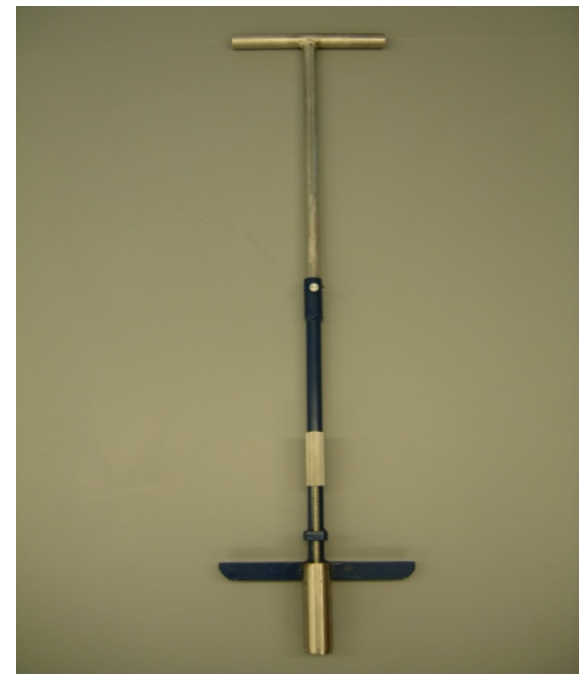

Figure 19 - Step Soil Probe coring dev ice

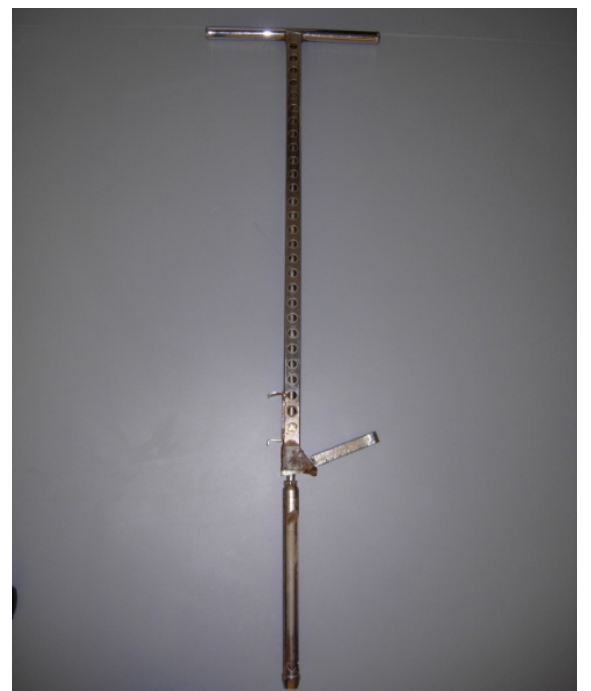

Figure 18 - CRREL coring device

\subsection{Soil Sampling Methods}

Established methods issued by the EPA, such as Method 8330, have been utilized since the early 1990 's for the collection and analysis of energetic material residues in soil. These methods rely on traditional approaches for sample collection and analysis and, in the case of energetic material residues, were found to produce data with a high degree of error. The recent development of Method $8330 \mathrm{~b}^{21}$ introduces several new techniques which aid in the reduction of sampling error and improvement in reproducibility and reliability of sample data. Correct implementation of the procedures outlined insures analysis of accurate and representative samples by removing bias from sample collection and hence the removal (or reduction) of uncertainty in subsequent data analysis.

The most notable change to sample collection in Method $8330 \mathrm{~b}^{21}$ is the elimination of biased sample collection by utilizing a multi increment approach to sampling. The Method also outlines the use of new tools and grid layouts to aid in the collection of representative samples for analysis. 


\section{4a. Composite (bias) grab sampling}

Traditionally soil sampling is carried out using what is known as the grid-node sampling strategy. This involves the collection of one or several discrete samples from within a grid area. The tools used for collection vary and as such the depth of sampling also varies. When samples from within a grid area are combined they are often manually mixed and split in the field to reduce sample volume before being sent for laboratory analysis.

This approach to sampling is very general and does not account for the unique nature of specific environmental contaminants. In the case of energetic material residues it does not account for their particulate nature or random distribution associated with explosive detonations. Due to the spatial and compositional heterogeneity of these analytes that are distributed as particles within soil the major source of error comes from collection and sampling.

\section{4b. Multi-increment Sampling}

A sampling plan must account for compositional and distribution heterogeneity if samples obtained using the strategy are to be representative of the area sampled. ${ }^{19}$ The errors associated with these types of heterogeneity are inversely proportional to the samples mass and the number of increments used to build the sample, respectively. To minimize these errors a $1 \mathrm{~kg}$ sample should be collected via at least 30 evenly spaced increments using a serpentine sampling pattern similar to that depicted in Figure 20.

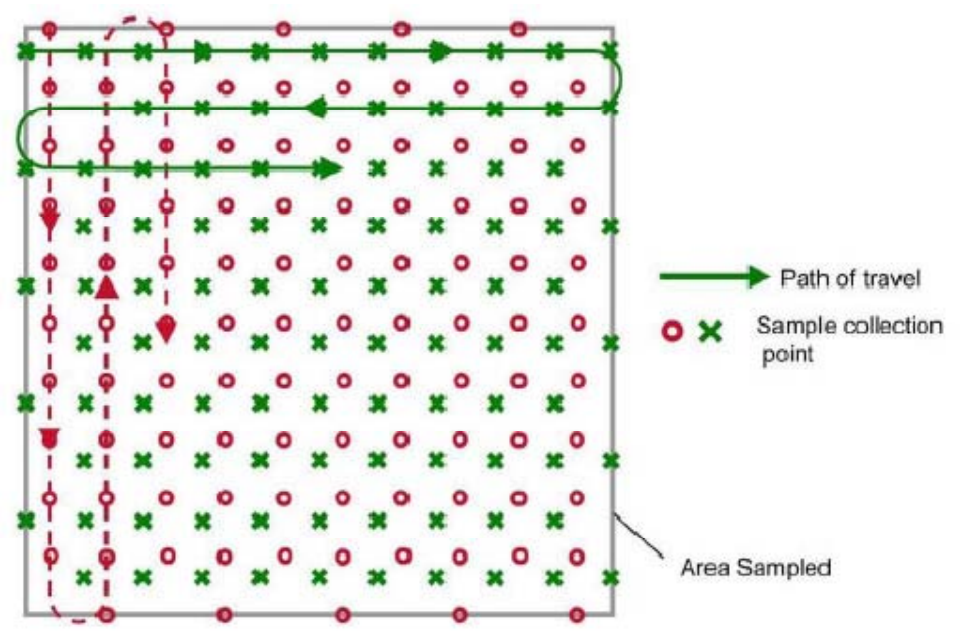

Figure 20 - Schematic representation of systematic-random 100 increment sampling pattern
The recommended decision unit for sampling areas with a defined target or target debris is $50 \mathrm{~m} \times 50 \mathrm{~m}$, centered on the target. If low-order-detonation has occurred, or chunks of energetic residue are visible on the surface soil, a $10 \mathrm{~m} \mathrm{x}$ $10 \mathrm{~m}$ grid is centered on that area or item and sampled separately from the larger grid (as shown in Figure 21). Heavily cratered areas are sampled using a $50 \mathrm{~m} \mathrm{x}$ $50 \mathrm{~m}$ decision unit, divided into twenty-five $10 \mathrm{~m} \times 10 \mathrm{~m}$

cells, as shown in Figure 22. In either case, the $10 \mathrm{~m} \times 10 \mathrm{~m}$ cells in the decision units would each be sampled in 100 increments using the sampling pattern depicted in Figure $20 .{ }^{19}$ 


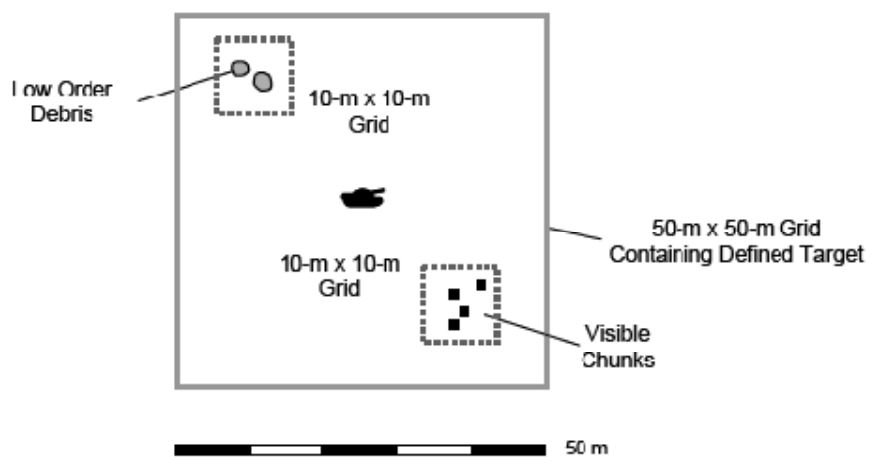

Figure 21 - Schematic representation of the recommended decision unit for a target area in the impact area of an artillery range

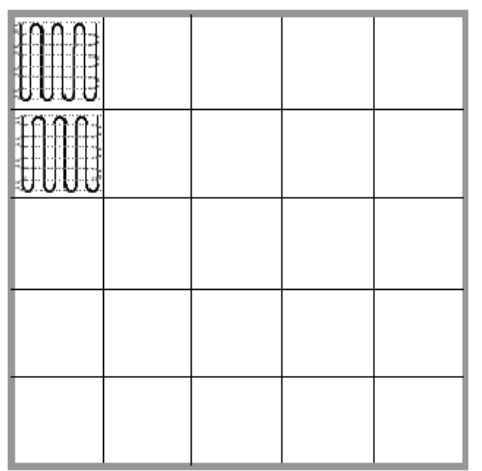

Figure 22- Schematic representation of sampling pattern for samples in $50 \times 50 \mathrm{~m}$ grids

The research discussed in this thesis aimed to determine if contamination was present in the selected areas and, if so, at what concentrations. The rounds studied in this project were comparable to those discussed in CRREL's report, ranging from $60 \mathrm{~mm}$ mortars to $105 \mathrm{~mm}$ Howitzer rounds. In addition, most of the sites sampled were of low ordered detonations. Therefore, a decision unit similar to the one depicted in Figure 21 was appropriate. In most cases, however, environmental constraints precluded the use of the recommended $50 \mathrm{~m} \times 50 \mathrm{~m}$ decision unit. Instead, $10 \mathrm{~m} \times 10 \mathrm{~m}$ decision units were centered over the crater and/or debris, where possible. At least 30 and, preferably closer to 100, increments were obtained from each decision unit, using the sampling pattern illustrated in Figure 23, to insure a representative sample. 


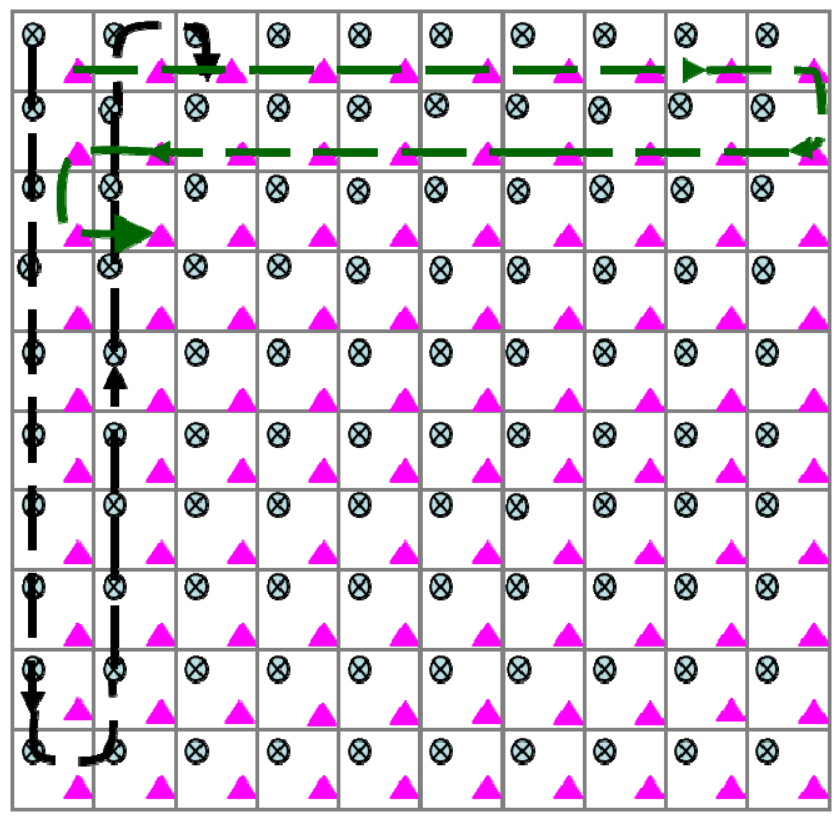

Figure 23- Schematic representation of a sampling pattern used for replicate analysis in this project

\section{4c. Depth Profile Sampling}

CRREL recommends profile sampling areas, such as hand grenade ranges, where transport and deposition of energetic material residues is expected to have occurred to determine the depth at which these residues have migrated into soils. At least 5 profile samples should be taken at $10 \mathrm{~cm}$ intervals to a depth of at least $30 \mathrm{~cm}$. These samples should be gathered in the most heavily cratered areas of the decision unit. The samples are then divided into depth increments (i.e 0-10 cm, 10-20 cm, 20-30 cm, etc) and the increments are combined to yield a composite sample for that depth range (see Figure 24).

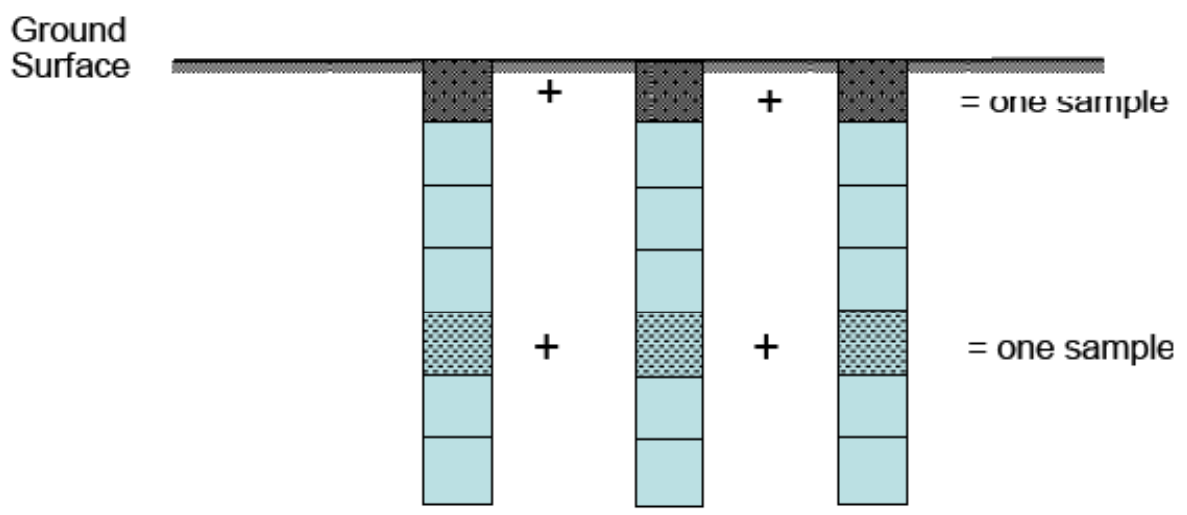

Figure 24 - Schematic of procedure used to gather multi-increment profile samples where transport and deposition of energetic materials is expected.

Due to the limited number of samples gathered, this technique is not suitable for estimating the concentration of explosives residues in a sub-surface layer across the entire 
decision unit. At least 30 profile samples must be gathered to estimate concentrations for the entire decision unit.

This technique was employed in this research for areas where visible explosives residues were present.

\subsection{Sample Preparation}

The practice of collecting a small number of unrepresentative samples for determination of UXO residues has been shown to lead to large degrees of error in sample data. Due to the spatial heterogeneity of energetic material residues, Method $8330 \mathrm{~b}^{21}$ recommends a multi-increment field sampling approach as a means of providing representative samples and improving surface characterization. The collection method produces sample data that provide a greater degree of statistical confidence compared with that obtained from discrete sample collection. The multiincrement field sampling must be followed by an in-laboratory sub-sampling via a multiincrement collection of ground soil to provide the overall desired improvement of statistical data.

The most notable changes to the sub-sampling method between EPA 8330 and EPA 8330b include: mechanical grinding of the complete sample received for analysis, collection of a $10 \mathrm{~g}$ sub-sample via a multi increment collection approach, extraction in $20 \mathrm{~mL}$ of solvent with the option of using an orbital shaker table and the collection and analysis of triplicate samples for every 5 to 20 samples processed.

The method outlined here (unless stated) is based wholly on EPA 8330b. Adequate care was taken throughout to avoid cross contamination between samples.

Field samples were received into the laboratory in tightly sealed $3 \mathrm{~mm}$ thick plastic bags. Soil was removed and placed on a large aluminum baking sheet covered completely with aluminum foil. Samples were broken up and separated if needed and allowed to dry completely. If soil was too wet to break up sufficiently it was broken up by hand at later time and allowed to dry further.

Soils were passed through a $2 \mathrm{~mm}$ sieve. Stones and plant debris were removed by hand.

The complete $<2 \mathrm{~mm}$ fraction was mechanically ground using a Shatterbox 8510 (SPEX Industries, Inc., NJ) (for complete SOP see Appendix B) to obtain a particle size of $\sim 10 \mu \mathrm{m}$ (Note: the recommended particle size outlined in EPA 8330b is $75 \mu \mathrm{m}$ ). The Shatterbox was operated for periods of $60 \mathrm{~s}$ to minimize analyte loss due to thermal degradation. The particle size reduction achieved, $\sim 10 \mu \mathrm{m}$, greatly reduces fundamental error prior to sub-sampling. The ground sample was stored in a plastic zip-lock bag prior to extraction. Blank, negative controls and spiked, positive controls were ground using the same procedure.

The extraction followed an SOP developed in-laboratory (for complete SOP see Appendix C). Sample selection for extraction followed a multi-increment approach to further reduce the uncertainty between sub-samples. Ground soil was mixed gently in the plastic bag before carefully spreading it out onto a sheet of aluminum foil to a thickness of approximately $2.5 \mathrm{~cm}$ (1 in.). 30 increments $(\sim 0.3 \mathrm{~g})$ were collected from the entire depth at regular intervals 
throughout the sample to form a $10 \mathrm{~g}$ composite sub-sample. The soil was weighed directly into a $60 \mathrm{~mL}$ glass jar which was sealed tightly with a PTFE-lined cap for storage prior to extraction.

The $10 \mathrm{~g}$ sub-sample of soil was extracted in $20 \mathrm{~mL}$ of acetonitrile. After addition of the extraction solvent the glass jar was vortex swirled for one minute before securely placing on a platform shaker table (VWR Mini Orbital Shaker) at a speed of $150 \mathrm{rpm}$ for $18 \mathrm{hrs}$.

After extraction the sample jar was allowed to stand for 30 minutes until particulates were sufficiently settled. The liquid extract was removed using a glass pipette and passed through a PTFE filter with a $0.5 \mu \mathrm{m}$ pore size. Collection was directly into analytical vials, carrying out any relevant dilutions appropriate for subsequent analyses.

\subsection{Instrumental Analysis}

Detection of the explosives listed in EPA Method $8330 \mathrm{~b}^{21}$ was carried out using a PerkinElmer Series 200 HPLC-UV system. An external calibration was performed by preparing calibration standards of 50, 200, 500, 700 and $1000 \mu \mathrm{g} / \mathrm{L}$ containing all the explosives in EPA Method 8330b. These components included TNT, HMX, RDX, 1,3-DNB, 1,3,5-TNB, 2,4-DNT, 2,6DNT, 2-NT, 3-NT, 4-NT, 2-ADNT, 4-ADNT, Tetryl, and NB. Calibration curves of each component were created with correlation coefficients for each compound being $>.99$. The extracts from trip 2 were diluted 1:4 in the mobile phase prior to injection into the HPLC. These instrumental conditions are summarized in Table 4.

Table 4- HPLC-UV conditions

\begin{tabular}{|c|c|c|}
\hline Column & Dionex Acclaims E1 & Dionex Acclaims E2 \\
\hline Detection Wavelength & $254 \mathrm{~nm}$ & $254 \mathrm{~nm}$ \\
\hline Column Temperature & $32^{\circ} \mathrm{C}$ & $30{ }^{\circ} \mathrm{C}$ \\
\hline Injection Volume & $100 \mu \mathrm{L}$ & $100 \mu \mathrm{L}$ \\
\hline Run Time & 50 minutes & 50 minutes \\
\hline Mobile Phase A & organic free water & organic free water \\
\hline Mobile Phase B & methanol & methanol \\
\hline Mobile Phase Composition & $48 \% \mathrm{~A}$ & $43 \% \mathrm{~A}$ \\
(isocratic elution) & $52 \% \mathrm{~B}$ & $57 \% \mathrm{~B}$ \\
\hline
\end{tabular}


The two columns used in this analytical analysis included the Acclaims E2 and E1 columns (Dionex Corporation, Sunnyvale, CA). These columns provided baseline resolution of all 14 compounds (Figure 51) and, in conjunction with each other, provided confirmational data. All extracts were first run on the E2 column to provide initial hits of possible explosives present in the extract (Appendix E). For QA/QC purposes, a blank, mid-point calibration standard followed by another blank were first run on the HPLC system at the beginning of each day prior to running extracts. The extracts were run in the same order as they were ground.

The HPLC analysis utilizing the E2 column included a $100 \mu \mathrm{L}$ injection, an isocratic elution with a mobile phase of 43/57 organic free water/methanol at a flow rate of $1 \mathrm{~mL} / \mathrm{min}$, and a column temperature of $30^{\circ} \mathrm{C}$. The UV-vis detector was set at $254 \mathrm{~nm}$, which is a common wavelength used to detect organic molecules. Once all extracts were run on the E2 column, any samples with initial hits were re-run on the E1 column for confirmation (Appendix F). All analytical conditions utilizing the E1 column were the same as those for the E2 except the mobile phase was changed to $48 / 52$ organic free water/methanol (isocratic elution) and the column temperature was increased to $32^{\circ} \mathrm{C}$. 


\section{CHAPTER 3: SITE DESCRIPTIONS AND DEVIATIONS FROM SAMPLING PLAN}

\subsection{Overview}

Grids 14, 15 and XD were located within the Dolly Sods North Area, Grid 16 was in the Canaan Valley National Wildlife Refuge (NWLR) and Grids 19 and 20 were located at Canaan Valley Institute (CVI). In some cases, the coordinates for the field identified craters (those without USACE provided coordinates) as well as the crater coordinates for the USACE UXO findings do not align with the grid shapefiles. This is due to discrepancies between the "realtime" field recorded coordinates versus data that was post-processed. All grid coordinates were post processed, therefore, the grid shapefile should be regarded as the most accurate.

It is worth noting that some of the Grids had visible chunks of material (such as shown in Figure 38), which may have been gathered during sampling. Extraordinary measures were not taken, however, to include these chunks in either the multi-increment, composite bias, or depth profile samples. Any chunks present in the sample would have been excluded during the sample preparation procedure, specifically the sieving process, discussed in Section 2.5. Any material $>2 \mathrm{~mm}$ in diameter is not considered to be soil, is not included in the mechanical grinding process, and is, therefore, not analyzed for contamination. Any material that leached off the chunks and was either present in small enough particulates or adsorbed into the soil fraction of the sample would be included in analysis, however, and therefore the material present in the chunks could still be represented in the analyzed soil.

\subsection{Grid 14 - Dolly Sods Wilderness Area}

\section{Site and Decision Unit Description}

An $81 \mathrm{~mm}$ mortar was found in this location in 1997. This site was sampled during the June 2007 campaign as Grid 4 and during the August 2007 campaign as Grid 14. The site was steep, rocky, and vegetated (Figure 26), which led to shallow soil in some areas. Rain also left the soil wet. In centering the desired $10 \mathrm{~m} \times 10 \mathrm{~m}$ decision unit over the crater, the trail ran through the cell and the remainder, on the side of the trail opposite the crater, dropped into an incline that was too steep for safe or effective sampling. Therefore, the decision unit was decreased to $10 \mathrm{~m}$ wide $\mathrm{x} 5 \mathrm{~m}$ long (Figure 25). 


\section{Grid 14}

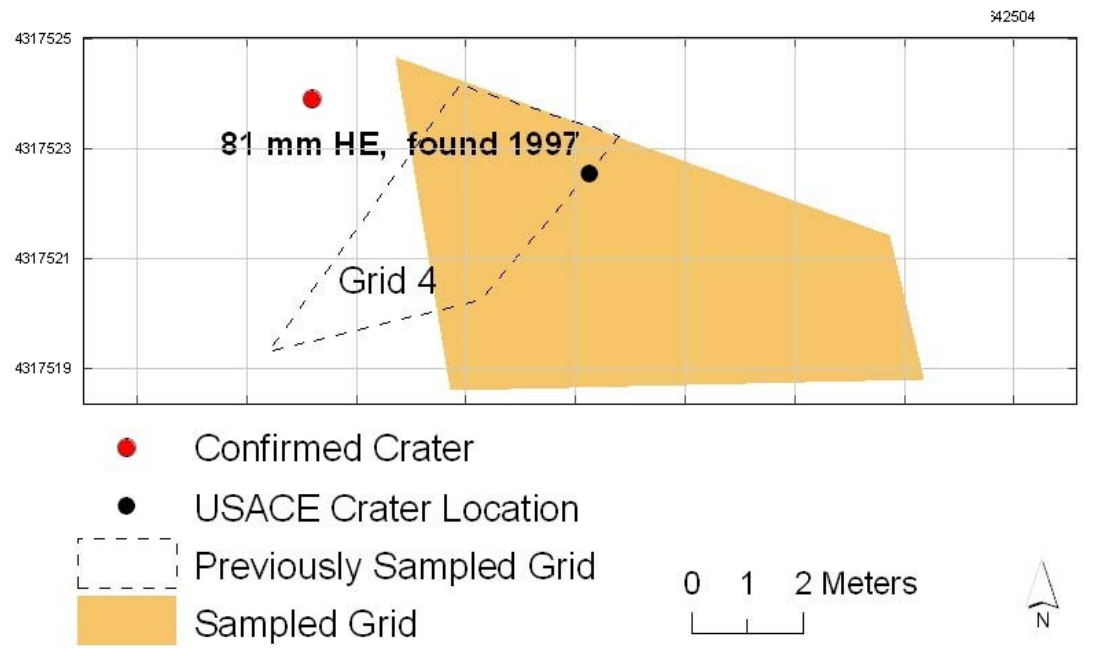

Figure 25 - GPS image of Grid 14 (August 2007 Field Campaign) and Grid 4 (June 2007 Field Campaign)

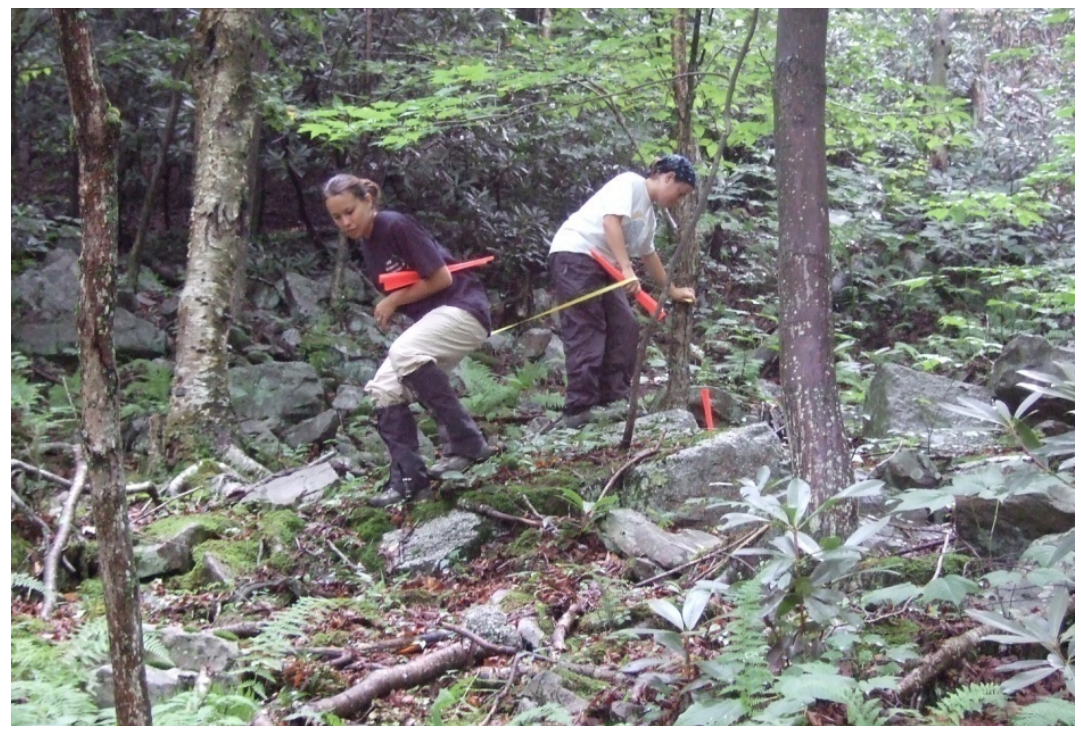

Figure 26 - Photograph of researchers staking the decision unit for Grid 14. The steep, rocky and heavily vegetated terrain presented challenges during sampling.

\section{Multi Increment Sampling}

Multi-increment sampling was employed, using the CRREL engineered coring device, and 76 of the 100 increments were successful. The 24 "missed" increments were not gathered due to environmental restrictions, such as rocks or tree roots. Due to time/weather constraints, and in the interest of re-visiting another site from the June 2007 campaign, replicate sampling was not performed on this site. 


\subsection{Grid 15 - Dolly Sods Wilderness Area}

Site and Decision Unit Description

This site, where an $81 \mathrm{~mm}$ mortar was detonated, was sampled during the June 2007 campaign as Grid 7 and during this campaign as Grid 15. The site was densely wooded and vegetated and the terrain was slightly sloping (Figures 28 and 29). The dense vegetation imposed major restrictions on sampling this site. Given the level of vegetation surrounding the crater, the desired $10 \mathrm{~m} \times 10 \mathrm{~m}$ area was unable to be cleared. Instead, the $3 \mathrm{~m} \times 3 \mathrm{~m}$ area closest to the crater served as the decision unit (Figure 27).

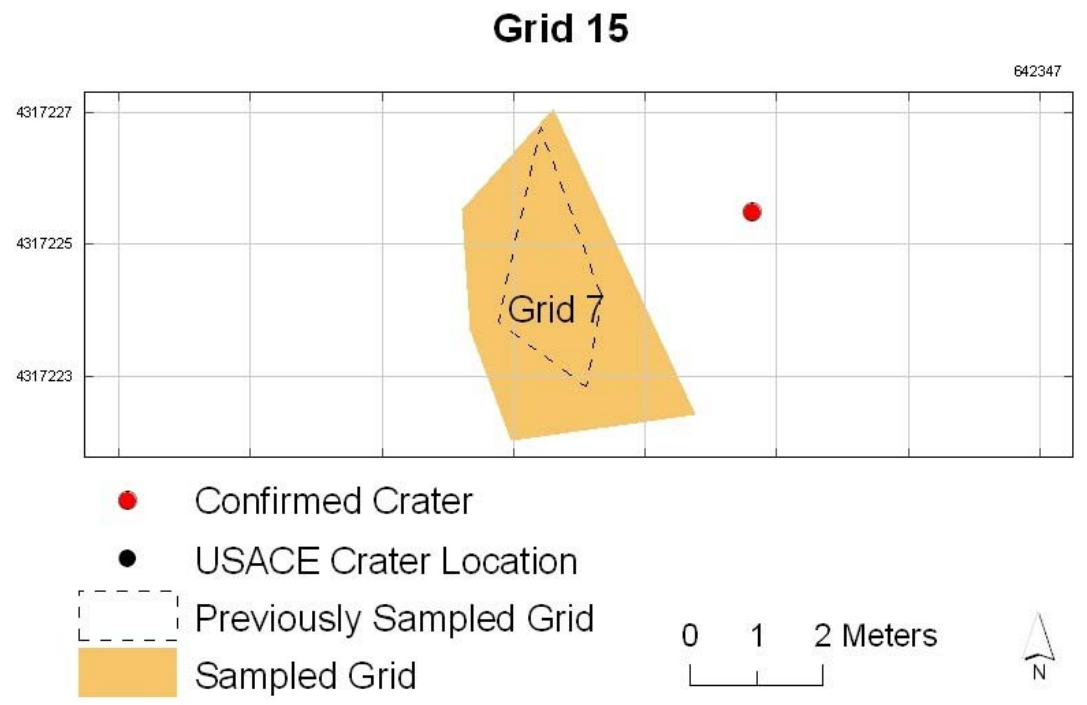

Figure 27 - GPS image of Grid 15 (August 2007 Field Campaign) and Grid 7 (June 2007 Campaign).

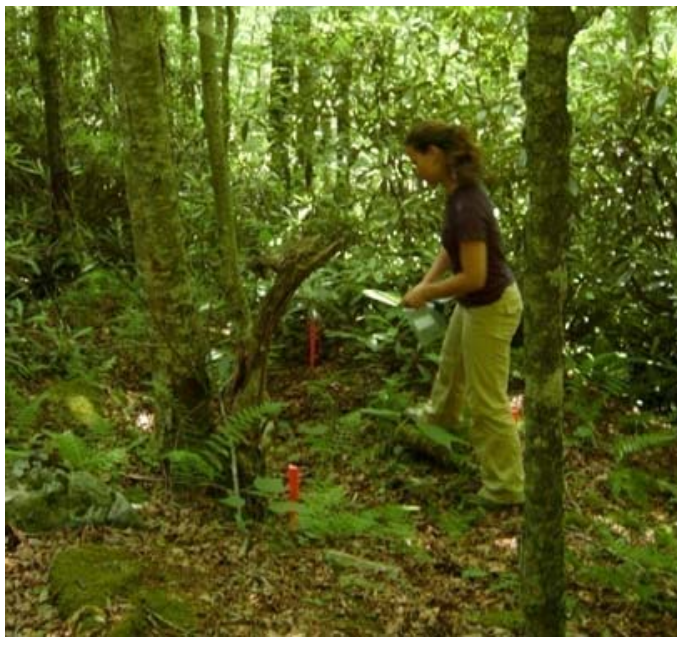

Figure 29 - Photograph of a research group member staking out the decision unit for Grid 15

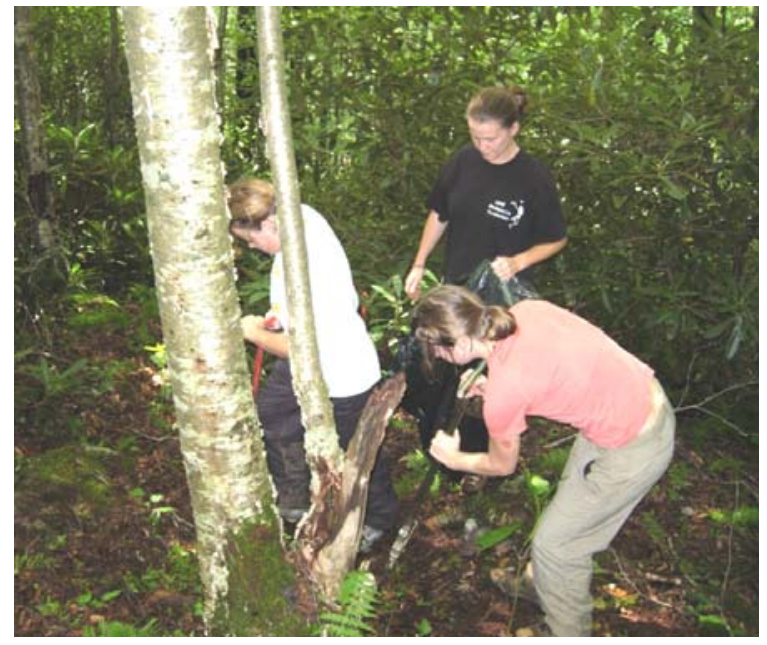

Figure 28 - Photograph showing the members of the research team collecting samples from Grid 15 using the CRREL coring devise and the step soil probe 


\section{Multi Increment Sampling}

The $3 \mathrm{~m} \times 3 \mathrm{~m}$ decision unit was sampled using the multi-increment method and the CRREL engineered coring device and 84 of the 100 increments were successful. The 16 "missed" increments were not gathered due to roots, rocks, or anomalies present within the decision unit. Due to time/weather constraints, replicate analysis was not performed on this site.

\subsection{Grid 16 - Canaan Valley National Wildlife Reserve}

Site and Decision Unit Description

A $105 \mathrm{~mm}$ Howitzer round was found in this location and detonated in the spring of 2007. The site was a rocky and densely wooded area placed on a considerable slope (Figure 31). The rainy weather and run-off from the dense canopy caused the soil to be wet. Exposed clay in the crater was muddy making sampling challenging. For the first time, a $10 \mathrm{~m} \times 10 \mathrm{~m}$ decision unit was able to be sampled (Figure 30).

\section{Grid 16}

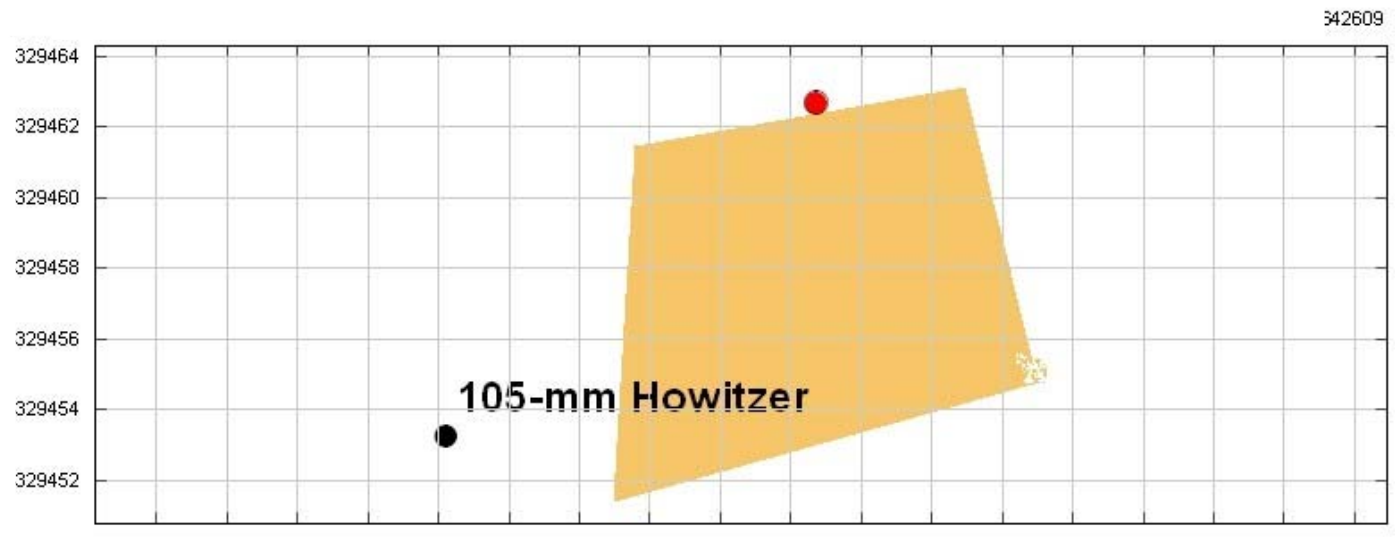

- Confirmed Crater

- USACE Crater Location

Sampled Grid
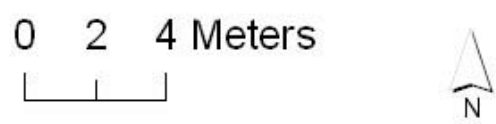

Figure 30 - GPS image of Grid 16. 


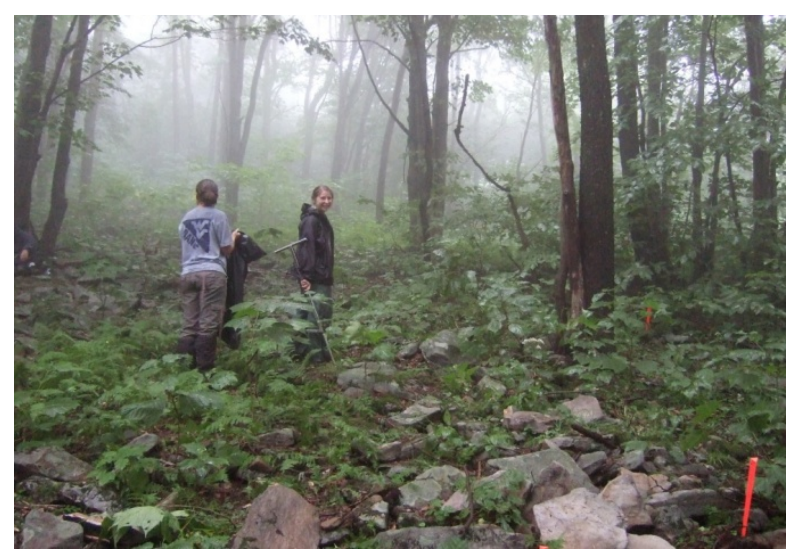

Figure 31 - Photograph showing researchers navigating the rocky and vegetated terrain to collect samples with the step soil probe.

\section{Multi Increment Sampling}

Given the ability to sample the optimum sized decision unit, replicate sampling was performed; however the abundance of rocks prohibited the use of the CRREL engineered coring device. Therefore, the step soil probe, supplied by the McDonald Research Group, was used instead. Multi-increment sampling was successful for 82 of 100 increments in the first replicate (WVU_2007_16_MI1) and 84 of 100 increments for the second replicate (WVU_2007_16_MI2). All "missed" increments were not gathered due mostly to rocks; however, where possible, the moss on the rocks was sampled.

Within the $10 \mathrm{~m} \times 10 \mathrm{~m}$ decision unit, a $2 \mathrm{~m} \times 2 \mathrm{~m}$ decision unit (Figure 32) was centered on the crater and sampled, separately, using the multi-increment method and 32 of 36 increments were successful.

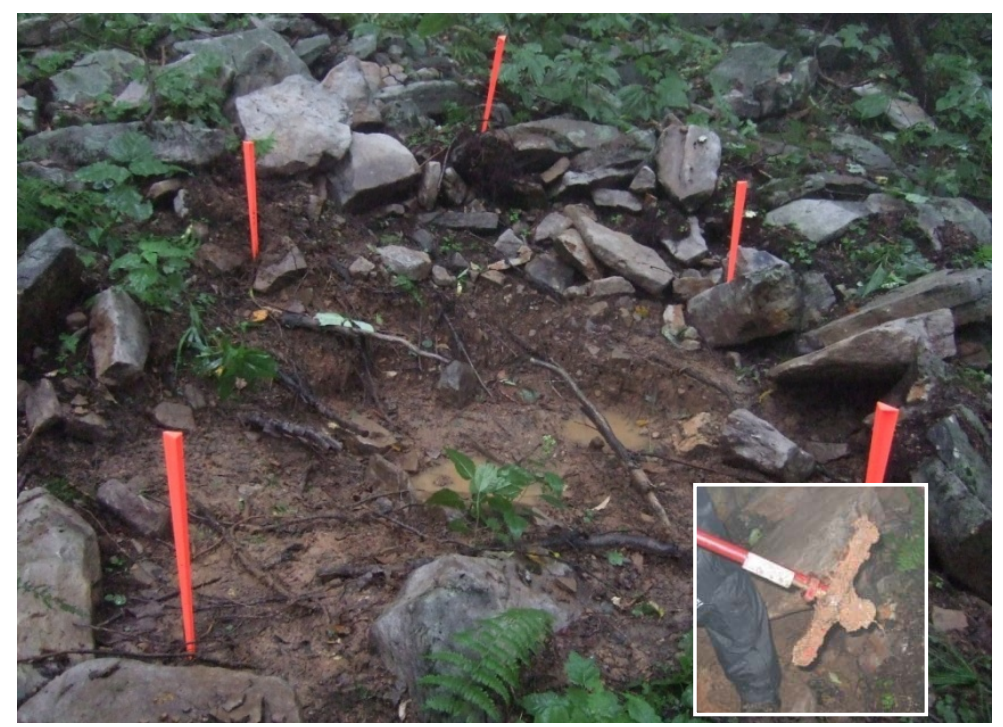

Figure 32 - Photograph showing the $2 \mathrm{~m}$ x $2 \mathrm{~m}$ decision unit surrounding the crater found within Grid 16. Exposed clay-like soil and mud presented challenges during sampling and cleaning (inset).

Note: The replicate analyses and the $2 m \times 2 m$ crater used the notes sections previously allotted for Grids 17 and 18. Therefore, there are no grids labeled as such in this report. Composite (Bias) Grab Sampling 
For comparative analysis, a composite random grab sample was gathered of the same $10 \mathrm{~m} \times 10 \mathrm{~m}$ decision unit used in the multi-increment method for Grid 16. Only the surface soil was sampled over the area of the grid using a sampling shovel.

\subsection{Grid 19 - Canaan Valley Institute}

Site and Decision Unit Description

This location was where an $80 \mathrm{~mm}$ rocket was found and detonated in November 2006. The site was flat, heavily wooded and vegetated (Figure 34), and the soil was very firm. The dense root structure from the trees added to the challenge of penetrating the soil surface during sampling. Despite the trees and vegetation, a $10 \mathrm{~m} \times 10 \mathrm{~m}$ decision unit was staked out (Figure $33)$.

\section{Grid 19}

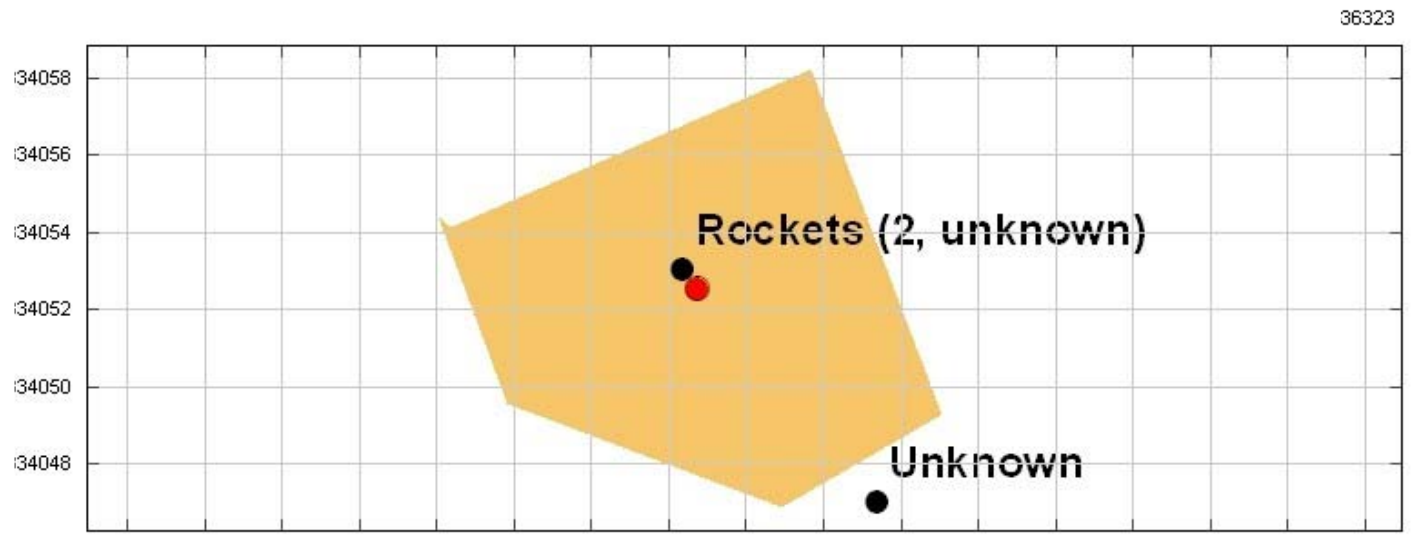

- Confirmed Crater

- USACE Crater Location

Sampled Grid

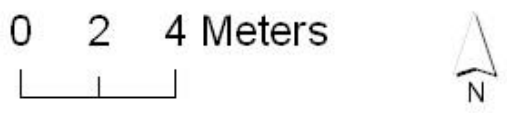

Figure 33 - GPS image of Grid 19.

Note: The bottom left hand corner of the grid in this image could not be sampled or mapped due to the presence of magnetic anomalies. 


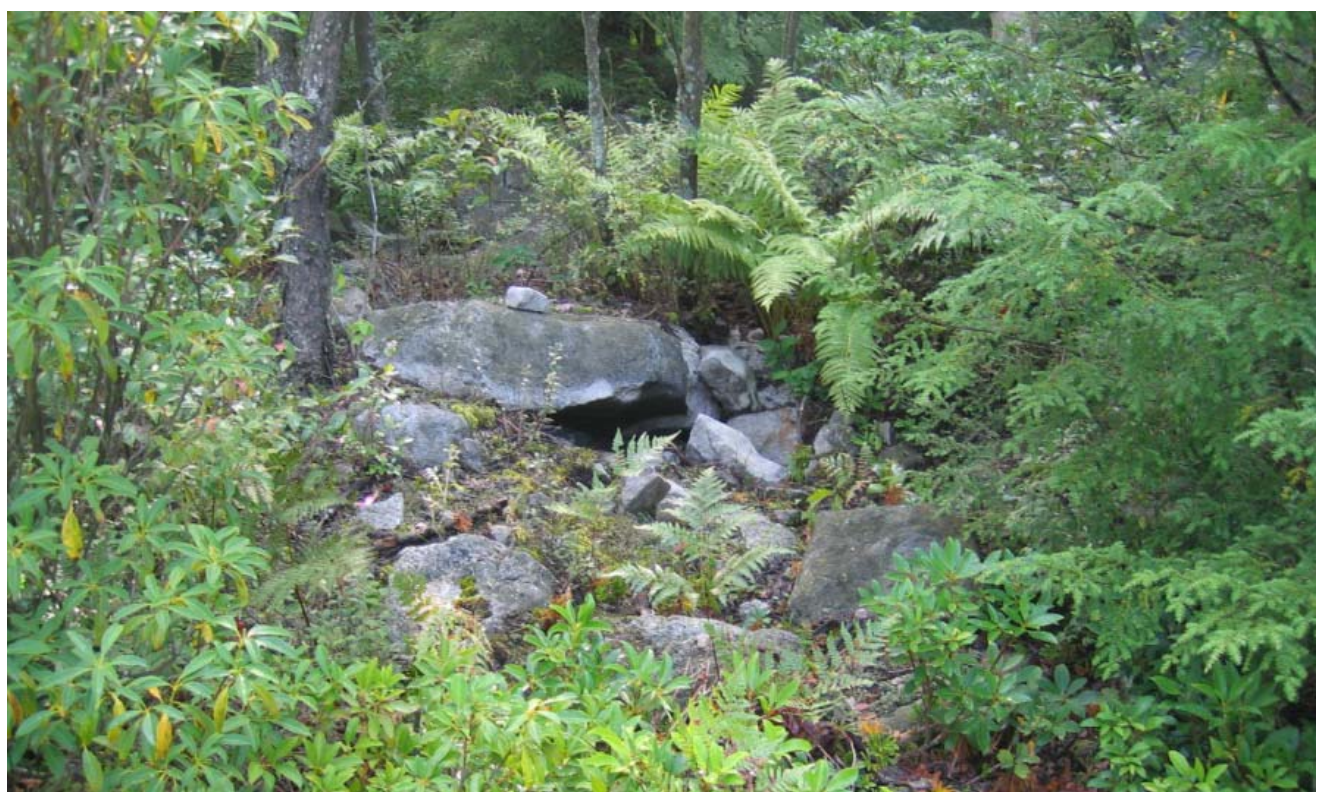

Figure 34 - Photograph showing Grid 19. The crater was nestled in the cluster of rocks shown in the center of the image.

\section{Multi-Increment Sampling}

Using the McDonald corer, multi-increment sampling was successful for 58 of 100 increments. The presence of a large number of anomalies prohibited the corner behind the crater from being sampled. In addition to the anomalies, trees and rocks contributed to the number of "missed" increments. 


\subsection{Grid 20 - Canaan Valley Institute}

Site and Decision Unit Description

The site, where an $80 \mathrm{~mm}$ rocket was found and detonated in December 2006, was flat and vegetated (Figure 36). The crater was located at the edge of a densely vegetated area which was highly contaminated with anomalies. By centering a $10 \mathrm{~m} \times 10 \mathrm{~m}$ decision unit on the crater, half of the decision unit fell in the dense vegetation, which was unsafe for foot traffic and sampling. Therefore, only the $10 \mathrm{~m}$ wide x $5 \mathrm{~m}$ long area in front of the crater served as the decision unit (Figure 35).

\section{Grid 20}

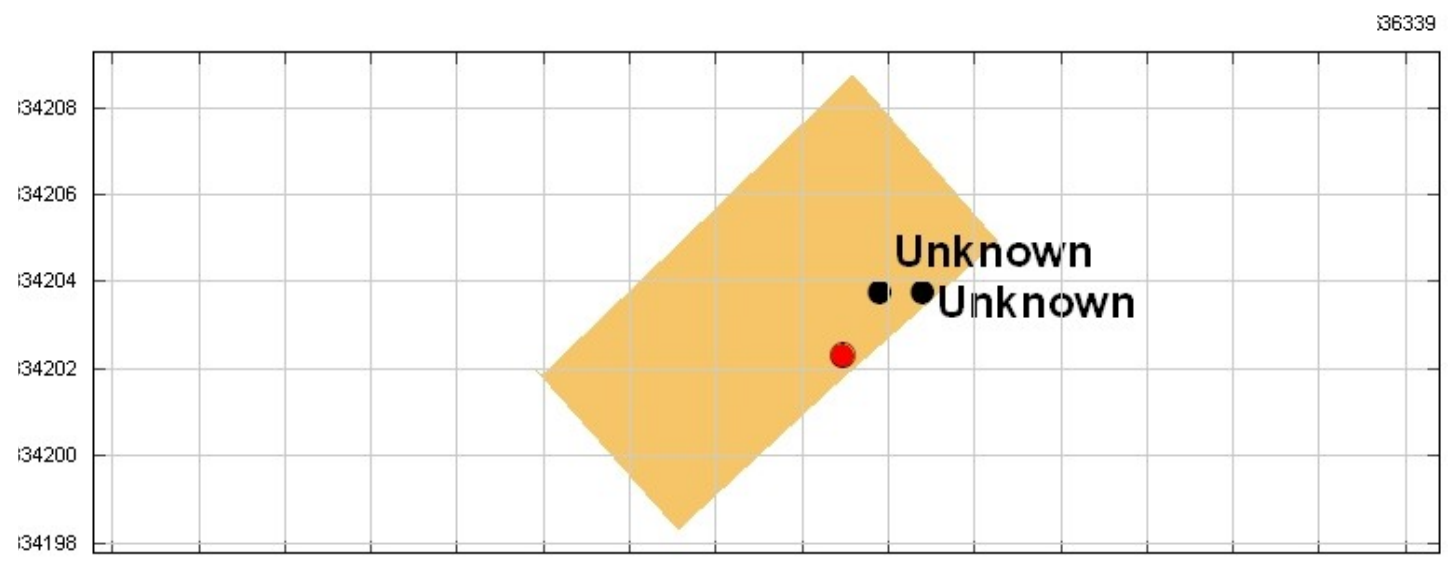

- Confirmed Crater

- USACE Crater Location

Sampled Grid

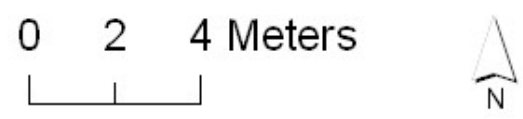

Figure 35 - GPS image of Grid 20. 


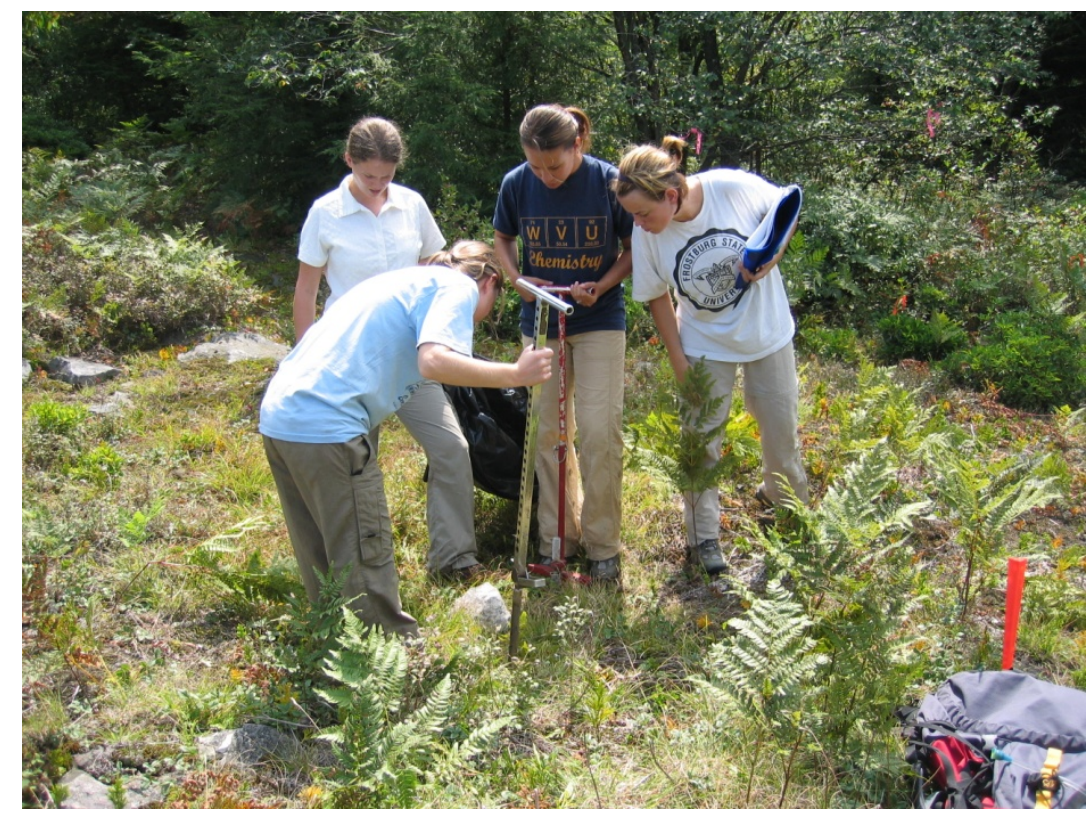

Figure 36 - Photograph showing members of the research team gathering soil samples from Grid 20 using the CRREL coring devise and the step soil probe.

\section{Multi-Increment Sampling}

Samples were gathered from this site using the CRREL engineered coring device. Since the decision unit was one-half the size of the optimum decision unit, 50 increments, rather than 100 , became the target sample. The area was sampled in triplicate using the multi-increment method and was successful for 48 of 50 increments in the first replicate (WVU_2007_20_MI1), 45 of 50 increments for the second replicate (WVU_2007_20_MI2), and 44 of 50 increments for the third replicate (WVU_2007_20_MI3). The "missed" increments were due to anomalies present within the decision unit.

\section{Composite (Bias) Grab Sampling}

Chunks of a white substance, assumed to be unexploded $\mathrm{C} 4$ remaining from the detonation, were visible within the crater area (Figure 38). The topsoil layer of the crater surface was sampled within the same $1 \mathrm{~m} \times 1 \mathrm{~m}$ cell used for the depth profiling to provide a composite bias grab sample (WVU_2007_20_Grab).

\section{Depth Profile Sampling}

Chunks of a white substance, assumed to be unexploded $\mathrm{C} 4$ remaining from the detonation, were visible on the surface of the crater area (Figure 38). Therefore, a depth profile sample was gathered across a $1 \mathrm{~m} \times 1 \mathrm{~m}$ area, which covered only the crater. This area was sampled in five locations to a depth of at least $12.7 \mathrm{~cm}(5 \mathrm{in}$.) (Figure 37). The 5 portions obtained from soil $12.7 \mathrm{~cm}$ (5 in.) deep and deeper were combined to form a composite sample (WVU_2007_20_CORE_2). The 5 portions obtained from soil above $12.7 \mathrm{~cm}$ (5 in.) deep were combined to form a composite sample (WVU_2007_20_CORE_1). 


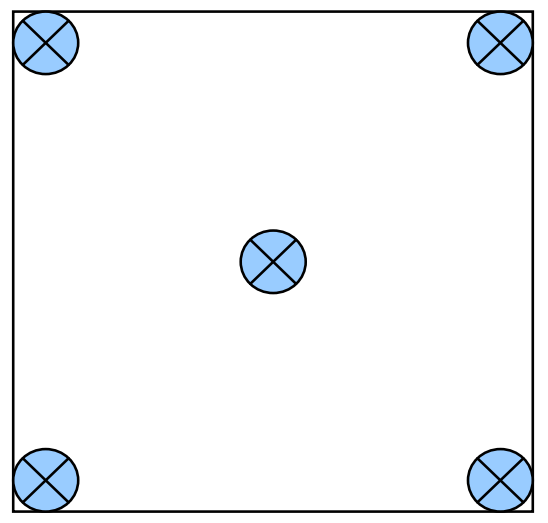

Figure 38 - Top-down view of depth profiling pattern used to sample the crater in Grid 20

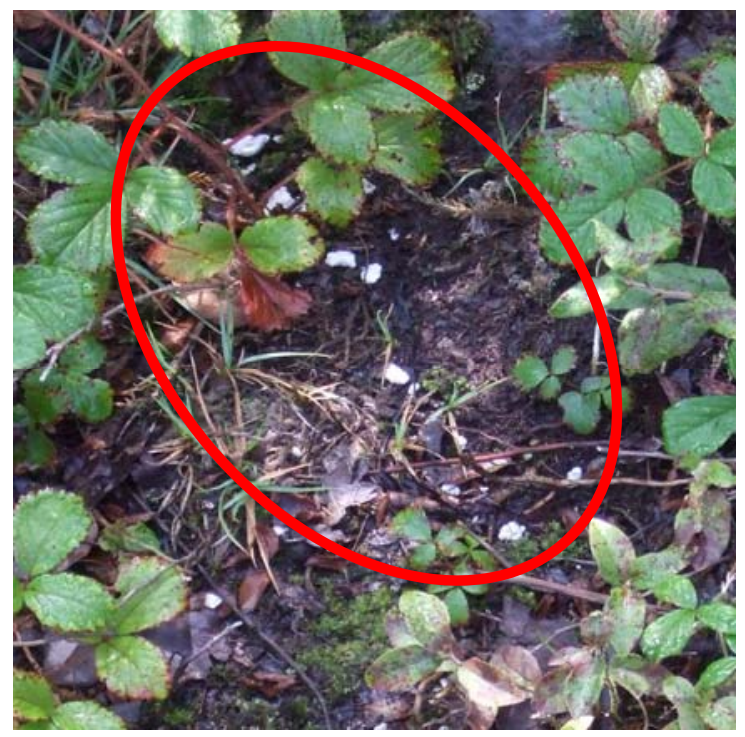

Figure 37 - Photograph showing white chunks of potential explosive visible on the surface of the crater in Grid 20.

\subsection{Site XD - Dolly Sods Wilderness Area}

Site and Decision Unit Description

While sampling Grid 3 during the June 2007 field campaign, the US Army UXO expert discovered an unexploded $60 \mathrm{~mm}$ mortar (Figure 39). This round was detonated in place and the site was sampled during the August 2007 field campaign. Due to the presence of many anomalies, the use of coring devices and the presence of more than one researcher were determined to be unsafe. Therefore, no decision unit was staked out and the multi-increment and depth profiling sampling plans were not employed.

\section{Grid 3}

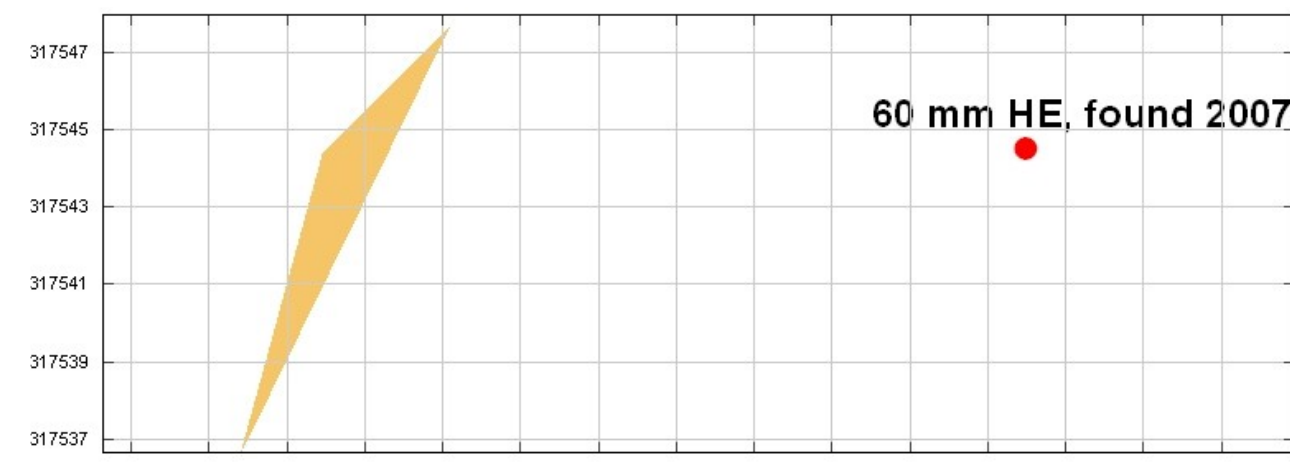

- Confirmed Crater

- USACE Crater Location

Sampled Grid

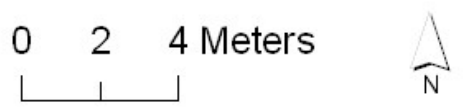

Figure 39 - GPS image of Grid 3 (June 2007 Field Campaign). Site XD was sampled where the $60 \mathrm{~mm} \mathrm{HE}$ is shown in the figure. 


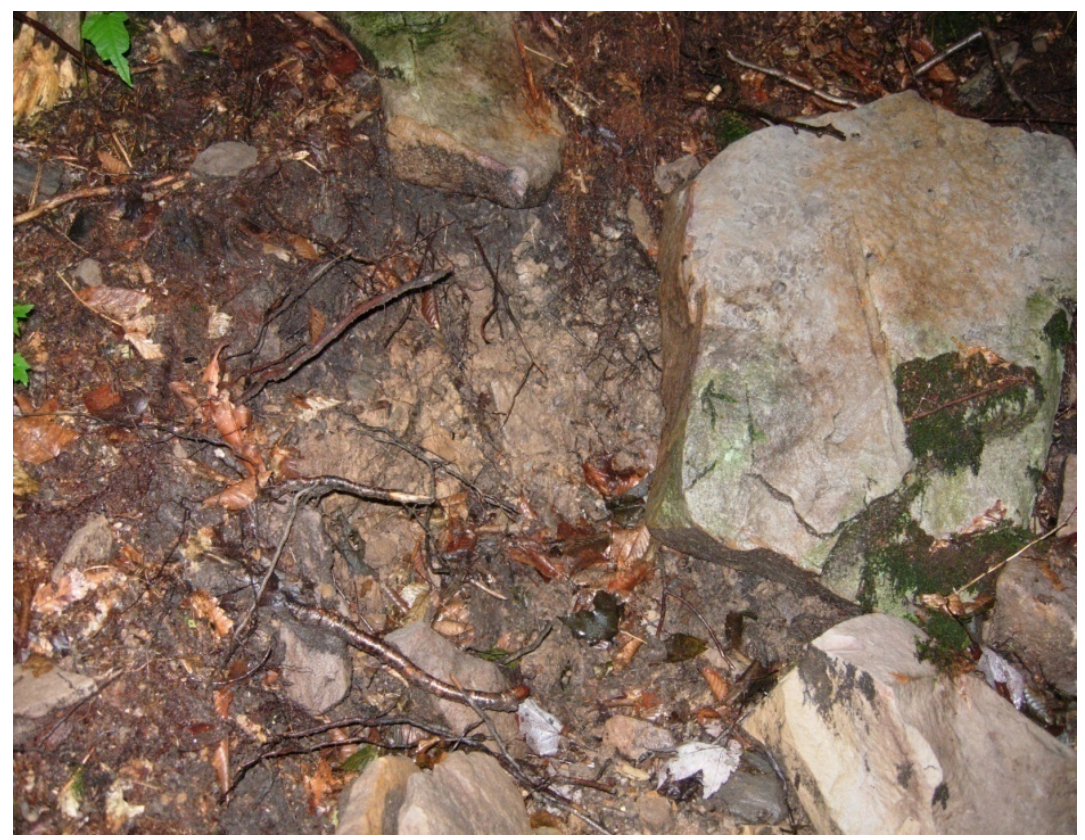

Figure 40 - Photograph showing the crater in the area where a $60 \mathrm{~mm}$ mortar was found and detonated during the June 2007 Field Campaign. The area was sampled as site XD during the August 2007 Field Campaign

\section{Composite (Bias) Grab Sampling}

A composite bias grab sample of the crater area (Figure 40) was gathered using the sampling shovel. Surface soil was gathered from the sides and center of the crater. Certain areas of the crater were subsequently sampled to provide sub-surface soil samples. Specific sampling sites are denoted on the Site XD notes page in Appendix D. 


\section{CHAPTER 4: RESULTS AND CONCLUSIONS}

\subsection{Quality Assurance Data}

\section{Instrument Validation}

The reproducibility of the HPLC-UV system was evaluated for all 14 components. Per EPA $8330 \mathrm{~b},{ }^{21}$ a calibration mix containing all 14 components was run in triplicate on the HPLC-UV in order to calculate the \%RSD of the instrument. Table 5 shows the \%RSD's for each component. The overall average of $3.3 \% \mathrm{RSD}$ was determined which is an acceptable $\% \mathrm{RSD}$ for this method.

Table 5 - Reproducibility results of all components $(n=3)$.

\begin{tabular}{|c|c|}
\hline Component & \%RSD \\
\hline HMX & 5.4 \\
\hline RDX & 2.7 \\
\hline 1,3,5-TNB & 3.0 \\
\hline 1,3-DNB & 3.4 \\
\hline NB & 3.0 \\
\hline TNT & 3.3 \\
\hline Tetryl & 3.1 \\
\hline 2,6-DNT & 3.4 \\
\hline 2,4-DNT & 3.1 \\
\hline 2-NT & 3.3 \\
\hline 4-NT & 3.0 \\
\hline 3-NT & 2.6 \\
\hline 4-ADNT & 4.0 \\
\hline 2-ADNT & 3.2 \\
\hline AVERAGE & 3.3 \\
\hline
\end{tabular}

\section{ERA Certified Reference Material}

A reference soil standard was purchased from ERA (Environmental Resource Associates, Arvada, CO) that included most of the explosives listed in the EPA 8330 method. It is important to note that this soil was spiked with explosives from liquid standards and not spiked with particulates (personal communication with Tim Miller, Organic Chemist for ERA, May 14, 2008). Therefore, this soil standard did not completely mimic what is found in the Dolly Sods or Canaan Valley areas, which were contaminated with particulate explosives. Three ERA soil standards underwent the same procedures as the Dolly Sods and Canaan Valley samples (see Section 2.5) except for the sieving process. The results were averaged and are shown in Table 6. Of the 14 compounds listed in the EPA 8330 method, 13 were present in the ERA soil standard. Our method detected all 13 explosives; however, only 7 explosives including RDX, 1,3,5-TNB, 1,3-DNB, 2,6-DNT, 2,4-DNT, 4-ADNT, 2-ADNT fell within the QC performance acceptable 
limits. The concentrations of explosives that did not fall within the range were slightly lower than the QC lower limit, except for HMX which was remarkably higher than the QC upper limit.

Table 6 - Results for ERA Soil Standards.

\begin{tabular}{|c|c|c|c|c|}
\hline \multirow[t]{2}{*}{ Component } & \multicolumn{2}{|c|}{$\begin{array}{l}\text { QC Performance Acceptance } \\
\text { Limits }\end{array}$} & \multirow{2}{*}{$\begin{array}{l}\text { Experimentally } \\
\text { Determined } \\
\text { Concentration* }\end{array}$} & \multirow[t]{2}{*}{ Within Range } \\
\hline & Lower Limit & Upper Limit & & \\
\hline $\mathrm{HMX}$ & 420 & 916 & 1100 & No \\
\hline RDX & 557 & 1100 & 780 & Yes \\
\hline $1,3,5-\mathrm{TNB}$ & 7150 & 15600 & 8400 & Yes \\
\hline 1,3-DNB & 5680 & 10100 & 5800 & Yes \\
\hline NB & 1640 & 3700 & 800 & No \\
\hline TNT & 1860 & 3090 & 1700 & No \\
\hline 2,6-DNT & 3030 & 6390 & 3200 & Yes \\
\hline 2,4-DNT & 2300 & 4420 & 2400 & Yes \\
\hline 2-NT & 2930 & 5160 & 1500 & No \\
\hline 4-NT & 2790 & 5500 & 2100 & No \\
\hline 3-NT & 2800 & 5270 & 1800 & No \\
\hline 4-ADNT & 776 & 1890 & 1000 & Yes \\
\hline 2-ADNT & 1530 & 2960 & 1600 & Yes \\
\hline
\end{tabular}

*Three trials.

\subsection{Results for Soil Analysis by HPLC-UV}

Appendix E includes representative chromatograms for analysis of each grid.

\section{2a Results for Grid 14 - Dolly Sods Wilderness Area}

The single sample taken from this grid was a multi-increment sample including 76 successful increments. After data analysis, there were no detectable explosives present in this grid.

\section{2b. Results for Grid 15 - Dolly Sods Wilderness Area}

One multi-increment sample was collected for Grid 15 consisting of 84 successful increments. The results are shown in Table 7. Nitrobenzene, a TNT degradation product, was the only explosive/degradation product detected at a concentration of $0.34 \mathrm{mg} / \mathrm{kg}$. 
Table 7 - Results for the multi-increment sampling from Grid 15 (Grid 7, June 2007 Field Campaign)

\begin{tabular}{|c|c|c|c|c|c|c|c|c|c|}
\hline \multirow[b]{2}{*}{ Sample ID } & \multirow{2}{*}{$\begin{array}{c}\text { Number of } \\
\text { samples } \\
\text { analyzed }\end{array}$} & \multirow{2}{*}{$\begin{array}{l}\text { Number of } \\
\text { increments } \\
\text { per sample }\end{array}$} & \multicolumn{7}{|c|}{ Concentration $(\mathrm{mg} / \mathrm{kg})$} \\
\hline & & & RDX & HMX & TNT & 2,4-DNT & 2,6-DNT & 2-ADNT & 4-ADNT \\
\hline WVU_2007_15_MI_1 & 1 & 84 & $<0.1$ & $<0.1$ & $<0.1$ & $<0.1$ & $<0.1$ & $<0.1$ & $<0.1$ \\
\hline Total & 1 & Maximum & $<0.1$ & $<0.1$ & $<0.1$ & $<0.1$ & $<0.1$ & $<0.1$ & $<0.1$ \\
\hline
\end{tabular}

\begin{tabular}{|c|c|c|c|c|c|c|c|c|c|}
\hline \multirow[b]{2}{*}{ Sample ID } & \multirow{2}{*}{$\begin{array}{c}\text { Number of } \\
\text { samples } \\
\text { analyzed }\end{array}$} & \multirow{2}{*}{$\begin{array}{l}\text { Number of } \\
\text { increments } \\
\text { per sample }\end{array}$} & \multicolumn{7}{|c|}{ Concentration $(\mathrm{mg} / \mathrm{kg})$} \\
\hline & & & 2-NT & 3-NT & 4-NT & 1,3,5-TNB & 1,3-DNB & Tetryl & NB \\
\hline WVU_2007_15_MI_1 & 1 & 84 & $<0.1$ & $<0.1$ & $<0.1$ & $<0.1$ & $<0.1$ & $<0.1$ & 0.34 \\
\hline Total & 1 & Maximum & $<0.1$ & $<0.1$ & $<0.1$ & $<0.1$ & $<0.1$ & $<0.1$ & 0.34 \\
\hline
\end{tabular}

\section{2c. Results for Grid 16 - NWLR}

Several samples were collected from Grid 16. Duplicate multi-increment samples were achieved on the larger $10 \times 10 \mathrm{~m}$ grid and one multi-increment sample was taken from a smaller 2 $\mathrm{x} 2 \mathrm{~m}$ grid surrounding the crater, see Fig 41. There were no explosives detected in either the 10 $\mathrm{x} 10 \mathrm{~m}$ or $2 \times 2 \mathrm{~m}$ grids. In addition, no detectable explosives were found in a random grab sample taken within the grid

$10 \mathrm{~m}$

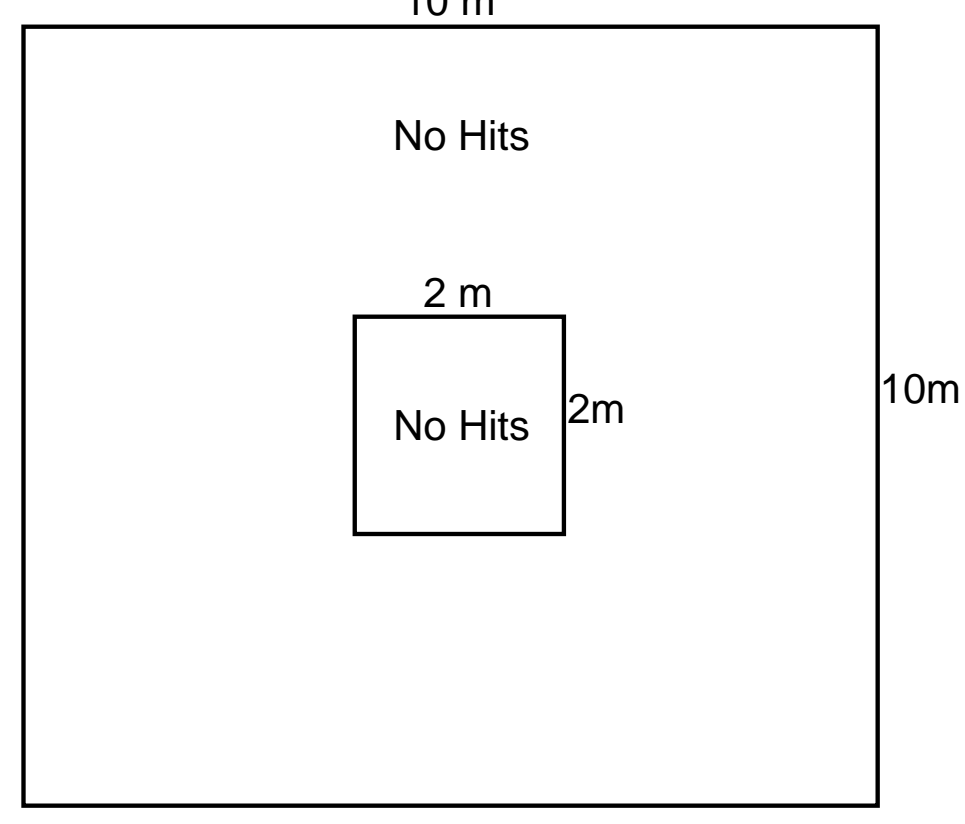

Figure 41 - Image depicting results from Grid 16: multi-increment sampling of the $10 \times 10 \mathrm{~m}$ grid and of the $2 \times 2 \mathrm{~m}$ grid surrounding the crater.

This grid was created around a detonated $105 \mathrm{~mm}$ Howitzer. This type of ordnance mostly contains nitrocellulose. Nitrocellulose is not a component of the EPA 8330 method and therefore, may be present in the soil but not detected using our method. Another explanation for 
not detecting any explosives is the possibility that a high order detonation occured. High order detonations produce particulates in the submicron particulate size, making it difficult to detect using this type of method.

\section{2d. Results for Grid 19 - Canaan Valley Institute}

One multi-increment sample and one random grab sample taken within the crater was collected from Grid 19. The multi-increment sample from a total of 58 increments, consisted of 1,3,5-TNB, a TNT degradation product, at a concentration of $1.2 \mathrm{mg} / \mathrm{kg}$. Conversely, the random grab sample from the same grid revealed RDX at $0.38 \mathrm{mg} / \mathrm{kg}$ present in the crater, see Table 8. A possible explanation for these results is that the ordnance contained TNT but was detonated using C4. Since C4 contains RDX, this would explain the presence of RDX in the crater.

Table 8 - Results for the multi-increment and random grab samples from Grid 19.

\begin{tabular}{|c|c|c|c|c|c|c|c|c|c|}
\hline \multirow[b]{2}{*}{ Sample ID } & \multirow{2}{*}{$\begin{array}{l}\text { Number of } \\
\text { samples } \\
\text { analyzed }\end{array}$} & \multirow{2}{*}{$\begin{array}{l}\text { Number of } \\
\text { increments } \\
\text { per sample }\end{array}$} & \multicolumn{7}{|c|}{ Concentration (mg/kg) } \\
\hline & & & RDX & HMX & TNT & 2,4-DNT & 2,6-DNT & 2-ADNT & 4-ADNT \\
\hline WVU_2007_19_MI & 1 & 58 & $<0.1$ & $<0.1$ & $<0.1$ & $<0.1$ & $<0.1$ & $<0.1$ & $<0.1$ \\
\hline WVU_2007_19_GRAB & 1 & - & 0.38 & $<0.1$ & $<0.1$ & $<0.1$ & $<0.1$ & $<0.1$ & $<0.1$ \\
\hline Total & 2 & Maximum & 0.38 & $<0.1$ & $<0.1$ & $<0.1$ & $<0.1$ & $<0.1$ & $<0.1$ \\
\hline
\end{tabular}

\begin{tabular}{|c|c|c|c|c|c|c|c|c|c|}
\hline \multirow[b]{2}{*}{ Sample ID } & \multirow{2}{*}{$\begin{array}{l}\text { Number of } \\
\text { samples } \\
\text { analyzed }\end{array}$} & \multirow{2}{*}{$\begin{array}{l}\text { Number of } \\
\text { increments } \\
\text { per sample }\end{array}$} & \multicolumn{7}{|c|}{ Concentration $(\mathrm{mg} / \mathrm{kg})$} \\
\hline & & & 2-NT & 3-NT & 4-NT & $1,3,5-\mathrm{TNB}$ & 1,3-DNB & Tetryl & NB \\
\hline WVU_2007_19_MI & 1 & 58 & $<0.1$ & $<0.1$ & $<0.1$ & 1.2 & $<0.1$ & $<0.1$ & $<0.1$ \\
\hline WVU_2007_19_GRAB & 1 & - & $<0.1$ & $<0.1$ & $<0.1$ & $<0.1$ & $<0.1$ & $<0.1$ & $<0.1$ \\
\hline Total & 2 & Maximum & $<0.1$ & $<0.1$ & $<0.1$ & 1.2 & $<0.1$ & $<0.1$ & $<0.1$ \\
\hline
\end{tabular}

\section{2e. Results for Grid 20 - Canaan Valley Institute}

Numerous samples were taken from Grid 20 including triplicate multi-increment samples, a random grab sample from the crater, and composite cored samples that were split into pieces according to its depth. All samples from this grid received hits for RDX and most for HMX. Samples taken within the crater, such as the grab sample and the composite cored samples, contained high concentrations of RDX and HMX. The concentration levels found in the grab sample were too high to detect using the HPLC. In addition, the concentration of RDX and HMX in one of the multi-increment samples were higher than the upper limit of quantitation (ULOQ) which is $>8.0 \mathrm{mg} / \mathrm{kg}$ (Table 9). 
Table 9 - Results for multi-increment, random grab, and cored soil samples from Grid 20.

\begin{tabular}{|c|c|c|c|c|c|c|c|c|c|}
\hline \multirow[b]{2}{*}{ Sample ID } & \multirow{2}{*}{$\begin{array}{c}\text { Number of } \\
\text { samples } \\
\text { analyzed }\end{array}$} & \multirow{2}{*}{$\begin{array}{l}\text { Number of } \\
\text { increments } \\
\text { per sample }\end{array}$} & \multicolumn{7}{|c|}{ Concentration (mg/kg) } \\
\hline & & & RDX & HMX & TNT & 2,4-DNT & 2,6-DNT & 2-ADNT & 4-ADNT \\
\hline WVU_2007_20_MI_1 & 1 & 48 & 1.7 & 1.1 & $<0.1$ & $<0.1$ & $<0.1$ & $<0.1$ & $<0.1$ \\
\hline WVU_2007_20_MI_2 & 1 & 45 & $>8.0$ & $>8.0$ & $<0.1$ & $<0.1$ & $<0.1$ & $<0.1$ & $<0.1$ \\
\hline WVU_2007_20_MI_3 & 1 & 43 & 3.2 & $<0.1$ & $<0.1$ & $<0.1$ & $<0.1$ & $<0.1$ & $<0.1$ \\
\hline WVU_2007_20_GRAB & 1 & - & $>8.0$ & $>8.0$ & $<0.1$ & $<0.1$ & $<0.1$ & $<0.1$ & $<0.1$ \\
\hline WVU_2007_20_CORE_1 & 1 & - & 6.6 & 2.4 & $<0.1$ & $<0.1$ & $<0.1$ & $<0.1$ & $<0.1$ \\
\hline WVU_2007_20_CORE_2 & 1 & - & 4.6 & 0.83 & $<0.1$ & $<0.1$ & $<0.1$ & $<0.1$ & $<0.1$ \\
\hline Total & 6 & Maximum & $>8.0$ & $>8.0$ & $<0.1$ & $<0.1$ & $<0.1$ & $<0.1$ & $<0.1$ \\
\hline
\end{tabular}

\begin{tabular}{|l|c|c|c|c|c|c|c|c|c|}
\hline & $\begin{array}{c}\text { Number of } \\
\text { samples } \\
\text { analyzed }\end{array}$ & $\begin{array}{c}\text { Number of } \\
\text { increments } \\
\text { per sample }\end{array}$ & 2-NT & 3-NT & 4-NT & 1,3,5-TNB & 1,3-DNB & Tetryl & NB \\
\hline WVU_2007_20_MI_1 & 1 & 48 & $<0.1$ & $<0.1$ & $<0.1$ & $<0.1$ & $<0.1$ & $<0.1$ & $<0.1$ \\
\hline WVU_2007_20_MI_2 & 1 & 45 & $<0.1$ & $<0.1$ & $<0.1$ & $<0.1$ & $<0.1$ & $<0.1$ & $<0.1$ \\
\hline WVU_2007_20_MI_3 & 1 & 43 & $<0.1$ & $<0.1$ & $<0.1$ & $<0.1$ & $<0.1$ & $<0.1$ & $<0.1$ \\
\hline WVU_2007_20_GRAB & 1 & - & $<0.1$ & $<0.1$ & $<0.1$ & $<0.1$ & $<0.1$ & $<0.1$ & $<0.1$ \\
\hline WVU_2007_20_CORE_1 & 1 & - & $<0.1$ & $<0.1$ & $<0.1$ & $<0.1$ & $<0.1$ & $<0.1$ & $<0.1$ \\
\hline WVU_2007_20_CORE_2 & 1 & - & $<0.1$ & $<0.1$ & $<0.1$ & $<0.1$ & $<0.1$ & $<0.1$ & $<0.1$ \\
\hline Total & 6 & Maximum & $<0.1$ & $<0.1$ & $<0.1$ & $<0.1$ & $<0.1$ & $<0.1$ & $<0.1$ \\
\hline
\end{tabular}

\section{2f. Depth Profile Results}

The depth profiles of Grid 20 are illustrated in Figure 42. The concentration value of RDX and HMX, the only 2 components detected in this Grid, were normalized by taking the depth value and dividing it by the ULOQ $(8.0 \mathrm{mg} / \mathrm{kg})$. Since some values exceeded the ULOQ and therefore, could not be determined, these normalized concentrations were set to $>1$. The trend for HMX shows that the normalized concentrations increase as the depth decreases, revealing that the higher concentrations of HMX are present in the top layer of soil. The trend for RDX represents similar data; however, a high concentration of RDX was found at a depth of 100-200mm, unlike most normalized depth profiles. Since RDX has a higher octanol:water coefficient than HMX, meaning that it has a higher affinity to organic matter, this may explain why there is a higher concentration of RDX at this depth of soil. Further research and soil profiles could explain this phenomenon. 


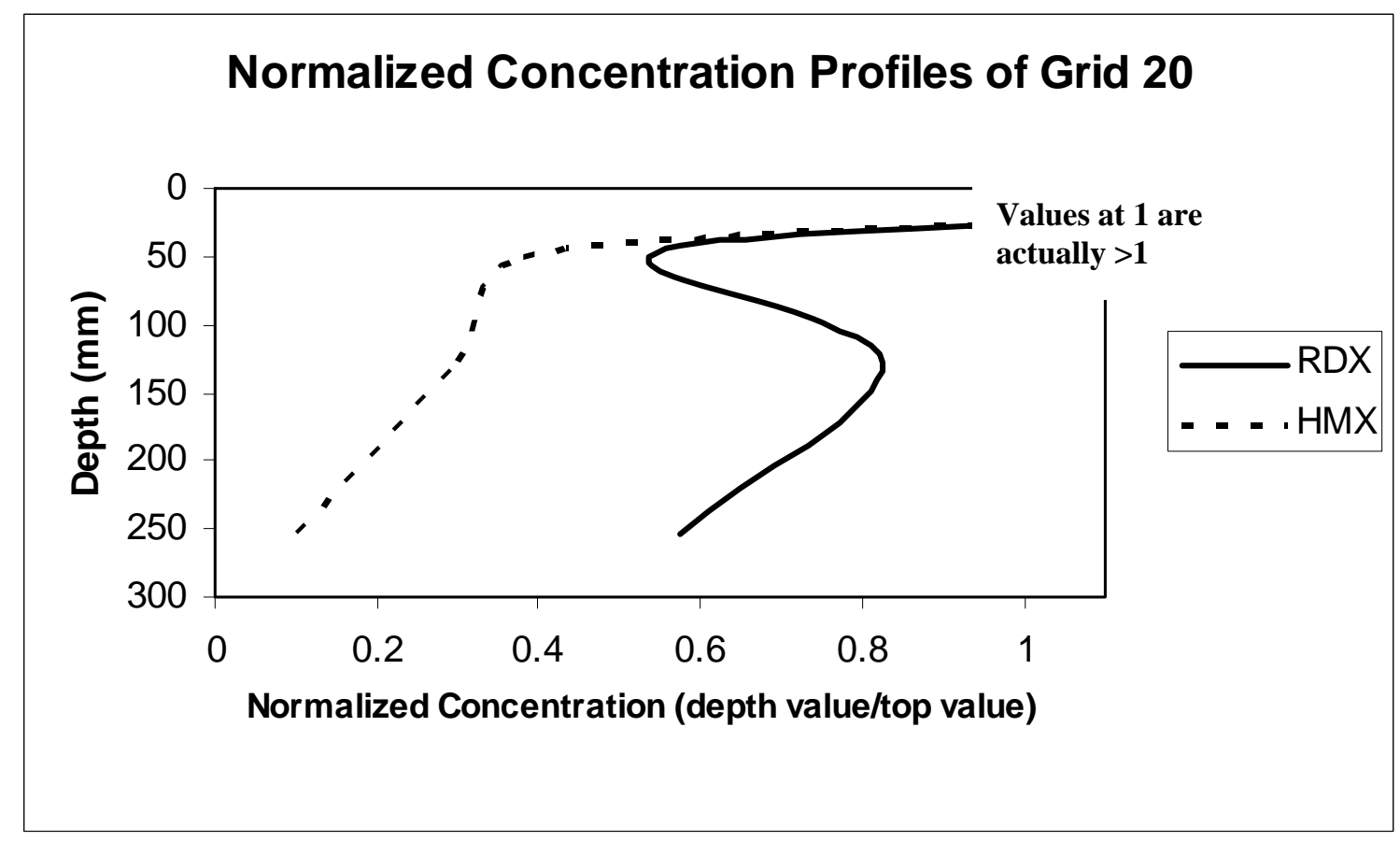

Figure 42 - Plot of Depth vs. Normalized Concentration of RDX and HMX from Grid 20.

\section{2g. Results for Grid XD - Dolly Sods Wilderness Area (former Grid 3 from June 2007 Field Campaign)}

Grid XD, or also known as Grid 3 from trip 1, produced high concentrations of TNT and TNT degradation products. These results were expected because 2 months prior to sampling this location the UXO was blown-in-place (June 2007). Results are shown in Table 10. The concentration levels of TNT and its main degradation products, 2-ADNT and 4-ADNT are high in each sample. These high concentrations reveal the need for further research in understanding the pathways of these explosive particulates, especially in a forest terrain such as that found in Dolly Sods and Canaan Valley. 
Table 10 - Results for random grab samples from Site XD, Grid 3 June 2007 Field Campaign.

\begin{tabular}{|c|c|c|c|c|c|c|c|c|c|}
\hline \multirow[b]{2}{*}{ Sample ID } & \multirow{2}{*}{$\begin{array}{c}\text { Number of } \\
\text { samples } \\
\text { analyzed }\end{array}$} & \multirow{2}{*}{$\begin{array}{c}\text { Location of } \\
\text { sample within } \\
\text { crater }\end{array}$} & \multicolumn{7}{|c|}{ Concentration $(\mathrm{mg} / \mathrm{kg})$} \\
\hline & & & $\mathrm{RDX}$ & $\mathrm{HMX}$ & TNT & 2,4-DNT & 2,6-DNT & 2-ADNT & 4-ADNT \\
\hline WVU_2007_XD_1 & 1 & inside crater & $<0.1$ & $<0.1$ & $>8.0$ & 1.6 & $<0.1$ & $>8.0$ & $>8.0$ \\
\hline WVU_2007_XD_2 & 1 & $\begin{array}{c}\text { left side of } \\
\text { crater }\end{array}$ & $<0.1$ & $<0.1$ & $>8.0$ & $<0.1$ & $<0.1$ & 2.1 & 1.2 \\
\hline WVU_2007_XD_3a & 1 & \begin{tabular}{|c} 
back side of \\
crater
\end{tabular} & $<0.1$ & $<0.1$ & 6.9 & 0.2 & $<0.1$ & 6.1 & 1.5 \\
\hline WVU_2007_XD_3b & 1 & \begin{tabular}{|c|}
$\begin{array}{c}\text { back side of } \\
\text { crater }\end{array}$ \\
\end{tabular} & $<0.1$ & $<0.1$ & 0.46 & $<0.1$ & $<0.1$ & 0.52 & 0.32 \\
\hline WVU_2007_XD 4 & 1 & below crater & $<0.1$ & $<0.1$ & 4.2 & $<0.1$ & $<0.1$ & 1.6 & 0.89 \\
\hline Total & 5 & Maximum & $<0.1$ & $<0.1$ & $>8.0$ & 0.2 & $<0.1$ & $>8.0$ & $>8.0$ \\
\hline
\end{tabular}

\begin{tabular}{|c|c|c|c|c|c|c|c|c|c|}
\hline \multirow[b]{2}{*}{ Sample ID } & \multirow{2}{*}{$\begin{array}{c}\text { Number of } \\
\text { samples } \\
\text { analyzed }\end{array}$} & \multirow{2}{*}{$\begin{array}{c}\text { Location of } \\
\text { sample within } \\
\text { crater }\end{array}$} & \multicolumn{7}{|c|}{ Concentration $(\mathrm{mg} / \mathrm{kg})$} \\
\hline & & & 2-NT & 3-NT & 4-NT & $1,3,5-$ TNB & 1,3-DNB & Tetryl & NB \\
\hline WVU_2007_XD_1 & 1 & inside crater & 0.6 & $<0.1$ & 1.6 & $<0.1$ & $<0.1$ & $<0.1$ & $<0.1$ \\
\hline WVU_2007_XD_2 & 1 & $\begin{array}{c}\text { left side of } \\
\text { crater }\end{array}$ & $<0.1$ & $<0.1$ & $<0.1$ & $<0.1$ & $<0.1$ & $<0.1$ & $<0.1$ \\
\hline WVU_2007_XD_3a & 1 & $\begin{array}{c}\text { back side of } \\
\text { crater }\end{array}$ & $<0.1$ & $<0.1$ & $<0.1$ & $<0.1$ & $<0.1$ & $<0.1$ & $<0.1$ \\
\hline WVU_2007_XD_3b & 1 & $\begin{array}{c}\text { back side of } \\
\text { crater }\end{array}$ & $<0.1$ & $<0.1$ & $<0.1$ & $<0.1$ & $<0.1$ & $<0.1$ & $<0.1$ \\
\hline WVU 2007 XD 4 & 1 & below crater & $<0.1$ & $<0.1$ & $<0.1$ & $<0.1$ & $<0.1$ & $<0.1$ & $<0.1$ \\
\hline Total & 5 & Maximum & 0.6 & $<0.1$ & 1.6 & $<0.1$ & $<0.1$ & $<0.1$ & $<0.1$ \\
\hline
\end{tabular}

\subsection{Discussion of Challenges}

The sample preparation and analysis techniques and methods described in EPA Method $8330 \mathrm{~b}^{21}$ provide a consistent and scientific means to process contaminated soil samples. While the sample gathering techniques and tools are ideal in certain environments and terrains, such as the flat Alaskan marshlands CRREL used to develop the multi-increment technique, the rocky, mountainous, and densely vegetated environments encountered during this research posed many challenges to the execution of the sampling.

The first problem presented by the terrain involved the use of the CRREL coring device. This tool was the preferred sampling tool for two reasons. First, the tool was designed for rapid, simple, and ergonomic sample recovery. Second, the CRREL coring device provided a consistent sample volume and sampled only the surface soil (to a depth of $5 \mathrm{~cm}, 2 \mathrm{in}$.). Alternative tools, such as sample shovels and soil probes, deliver a more inconsistent sample volume at varying depths. These tools require more physical strain and sampling to deliver samples comparable to those obtained by the CRREL device. The terrain found in some of the sites sampled in this research made the use of the CRREL coring device difficult. For example, rocks and vegetation were so dense in some areas that the coring device was too large. In these instances, the step soil probe was employed. While soil samples were gathered using this tool, the volume and depth of soil delivered in each increment differed from that of the CRREL device. These parameters would need to be accounted for in analysis of resultant data. 
The second challenge presented by the terrain involved the restriction of decision unit size. In order to be sampled, the entire decision unit must be scanned by a UXO Safety Specialist using the Schonstedt to locate magnetic anomalies. Some of the sites sampled in this research were so densely vegetated that the UXO Safety Specialist was unable to effectively scan the area. Entire portions of some decision units were omitted from sampling in some cases and in others the size of the decision unit was reduced to include only those areas safe for sampling. These restrictions resulted in the already reduced decision units $(10 \mathrm{~m} \times 10 \mathrm{~m}$ vs. the recommended $50 \mathrm{~m} \times 50 \mathrm{~m}$ ) to be reduced further and, in more comprehensive studies, would require more decision units to be sampled before determining the proper course of action for the area of interest. In addition, when the desired 100 increments are gathered from a smaller area, the surface soil is disrupted more noticeably than if the same number of increments were spread out over a larger area. Such an impact on the environment is an issue that must be addressed when samples are gathered from protected land such as wilderness areas.

Negotiating the terrain during sampling also presented issues. First, safety needed to be minded when maneuvering over large rocks (which were slippery during this research due to rain), steep inclines, fast-flowing steams, and dense vegetation. Second, when gathering samples and attempting to stay in a straight line to accomplish the rows and columns necessary for the multi-increment sampling, avoiding multiple obstacles such as rocks and trees made the task more difficult. These two issues combined to slow the process of sampling a decision unit considerably, when compared to sampling the same decision unit in a flat environment, and often prohibited the performance of replicate analysis.

Finally, if one considers the challenges presented for a $10 \mathrm{~m} \times 10 \mathrm{~m}$ decision unit and how these challenges would be amplified if a 50m x 50m decision unit was sampled, the necessity for a modified sampling method becomes apparent. The time required to perform thorough sampling of such a large area poses limitations on the number of sites which can be sampled during a field campaign with the team size used in this study. The restrictions placed on the number of team members who can safely follow a UXO expert into the field precludes the solution of simply increasing the size of the team to accomplish more rapid sampling. Utilizing additional UXO experts to rectify the ratio issue or increasing the number of field campaigns to insure the sampling of multiple sites would both necessitate increased financial support.

When faced with wet and muddy soil (Figure 32) due to weather or environment, the issue of cross-contamination must be considered. As illustrated in Figure 24, muddy and clay soils often adhere to sampling tools and require considerable effort to insure no soil is carried from one sampling site to another. The waste produced by cleansing this thorough must be carried out of the sampling area to be disposed. In this research, that meant loading the waste into packs and hiking back to the vehicles to dispose of the waste outside the wilderness area. If more or larger sites had been sampled, the waste produced would have required a disposal plan and/or another team member to assist with its transportation.

Problems exist with the analytical portions of EPA Methods 8095 and $8330 \mathrm{~b}$ as well. For example, despite the extensive sampling procedures and replicate analysis performed on Grid 16, no detectable concentrations of explosives residues were found in the recovered soil. Upon further research into the type of UXO detonated at this site revealed the predominant explosive 
in Howitzer rounds to be nitrocellulose, which is not included on the list of components detected with Method 8095 and 8330b. This could explain the absence of any analytical hits.

The use of a destructive charge, such as $\mathrm{C} 4$, to detonate UXO often removes the safety hazard posed by a potentially live round and the potential for further contamination by the remaining explosives residues in the UXO. However, the residues which remain from the unexploded charge left behind when excess charge is used in these "blow-in-place" detonations present environmental contaminations of their own. The combination of RDX/HMX was found to be present on the surface and to a depth of at least $20.3 \mathrm{~cm}$ (8 in.) in this research. Therefore, a charge which is more safely absorbed into the environment (such as ammonium nitrate) should be considered for removal of UXO.

With the exception of Site XD, all sites sampled in this research were locations were UXO had been previously discovered and detonated. Our team was provided with GPS coordinates for these locations and, in some cases, escorts in addition to the UXO expert to guide us to the exact location of the craters. In the big picture, Site XD represents the type of location this research seeks to benefit. Ideally, methodology should be in place to prepare teams who discover UXO to detonate the object and sample the area using a scientific and statistically sound method (such as the multi-increment method) and proper tools. In the sampling of Site XD, the need for further work to achieve this goal was made apparent.

Quality assurance and quality control procedures need to be employed to measure the accuracy of sample preparation and analysis techniques. These procedures include the use of controls, or standard reference materials of analytes in the same matrix expected in field samples. These control samples should mimic field samples as closely as possible, so for this research a soil sample spiked with trace amounts of particulate explosives residues is desired. For this research the only commercially available standard was employed, but this standard was a soil matrix spiked with trace amounts of liquid explosives residues. Since liquids have different chemical properties than solids, the standard may not accurately measure the efficiency of the sample preparation and analysis techniques utilized in this study.

\subsection{Conclusions}

The research presented here confirms that explosive residues were found in soils in areas where 'blow-in-place' detonation of UXO occurred. Explosive residues were found in surface soil and at depths of up to $20.3 \mathrm{~cm}$ (8 in.) providing evidence that the contaminants are able to migrate. Instrumental analysis, by high performance liquid chromatography (HPLC), of soil recovered from the sample sites showed the presence and concentrations of contaminants to be a function of parameters such as: time since detonation, type of original munitions, and type of charge used to destroy the UXO. In cases of aged detonation sites, the chemical signature was consistent with the degradation profile expected from weathering of residues present.

Table 11 provides a summary of contaminants found and concentrations detected. 
Table 11 - Summary of contaminant concentrations.

\begin{tabular}{|c|c|c|c|}
\hline Grid \# & Site Location & $\begin{array}{c}\text { Explosives } \\
\text { Present }\end{array}$ & Concentration \\
\hline 14 & Dolly Sods Wilderness Area & N/A & - \\
\hline 15 & Dolly Sods Wilderness Area & NB & $0.34 \mathrm{mg} / \mathrm{kg}$ \\
\hline 16 & Canaan Valley National Wildlife Refuge & $N / A$ & - \\
\hline \multirow{2}{*}{19} & \multirow{2}{*}{ Canaan Valley Institute } & RDX & $0.38 \mathrm{mg} / \mathrm{kg}$ \\
\hline & & $1,3,5-\mathrm{TNB}$ & $1.2 \mathrm{mg} / \mathrm{kg}$ \\
\hline \multirow{2}{*}{20} & \multirow{2}{*}{ Canaan Valley Institute } & RDX & $>8.0 \mathrm{mg} / \mathrm{kg}$ \\
\hline & & HMX & $>8.0 \mathrm{mg} / \mathrm{kg}$ \\
\hline \multirow{6}{*}{$X D$} & \multirow{6}{*}{ Dolly Sods Wilderness Area } & TNT & $>8.0 \mathrm{mg} / \mathrm{kg}$ \\
\hline & & 2,4-DNT & $0.2 \mathrm{mg} / \mathrm{kg}$ \\
\hline & & 2-ADNT & $>8.0 \mathrm{mg} / \mathrm{kg}$ \\
\hline & & 4-ADNT & $>8.0 \mathrm{mg} / \mathrm{kg}$ \\
\hline & & 2-NT & $0.6 \mathrm{mg} / \mathrm{kg}$ \\
\hline & & 4-NT & $1.6 \mathrm{mg} / \mathrm{kg}$ \\
\hline
\end{tabular}

A modified method is required for effective and efficient sampling of rocky, mountainous, and densely vegetated environments. These types of terrain, such as those encountered in this research, pose many challenges to the execution of the sampling under the multi-increment method and Method 8330b. While the sample gathering techniques and tools are ideal in certain environments and terrains, such as the flat Alaskan marshlands CRREL used to develop the multi-increment technique, the use of recommended tools was not always possible and the desired increment volume could not always be achieved in the wilderness area studied during this research. In addition, the disruption of surface soils and environments required to sample under these methods may be unacceptable in wilderness areas where environmental impact is strictly regulated. Besides the issues relating to sample collection, there were also shortcomings with the analytical portions of Methods $8330 \mathrm{~b}$ and 8095 . The inability of either method to detect nitrocellulose results in the inability to adequately analyze detonation sites of Howitzer rounds.

The type of charge employed in the detonation of UXO must be reviewed. The $\mathrm{RDX} / \mathrm{HMX}$ left behind when charges such as $\mathrm{C} 4$ were used to detonate UXO introduced contamination to a depth of at least $20.3 \mathrm{~cm}$ (8 in.). An explosive with less environmental impact, such as ammonium nitrate, should be considered. In addition, depth profile samples should be taken periodically to insure that contamination is not migrating down into the soil. These samples should be taken at fresh detonation sites as well as existing and aged craters.

Given the absence of particulate contaminant controls on the commercial market, there is still no realistic or reliable control protocol for measuring efficiency and error in analyses of these contaminants. 


\subsection{Future Research}

Given the issues encountered during the execution of this work (discussed in previous sections), some aspects of the project would be done differently in future research opportunities. Initially, the suitability of EPA Method $8330 \mathrm{~b}$ in rocky, heavily vegetated, and mountainous terrain would need to be evaluated. This would be done by first performing statistical analysis to determine the effect (if any) of the varied sample increment volume and depth on determination of contaminant concentration in areas where the step soil probe was used. In addition, the ideal number of increments for a $10 \mathrm{~m} \times 10 \mathrm{~m}$ decision unit in such terrain would need to be investigated to insure the effects of oversampling do not affect the results (by misrepresenting the sampled area) or the environment (by needlessly disrupting the sample site).

The analysis phase of the project would undergo some modifications as well. For example, when sub-sampling the mechanically ground sample, triplicate analysis should be performed for every fifth sample processed in order to account for distributional heterogeneity. Time and resources did not allow for such analysis during this project. When determining the concentrations of contaminant(s) present in the soil, those samples found to have concentrations $>0.8 \mathrm{mg} / \mathrm{kg}$ should be diluted until a more exact concentration could be calculated.

Aspects of the project pertaining to field screening and remediation should also be researched. Field screening techniques such as IMS could not be employed in this project due to the prohibition of the radioactive ionization source from wilderness areas. Techniques such as color tests, assays, canine olfactory, electrochemical, and laser detection should be considered for screening soil samples in the field to guide the placements of grids (particularly in areas were no crater and/or debris are visible). Once an area is sampled and the analyzed soil shows contamination at levels significant enough to warrant remediation, a finite window of time (approximately 70-120 days) exists in order to accomplish effective remediation. Remediation techniques, such as microbial degradation and soil removal, should then be evaluated to determine the most appropriate measure for safely neutralizing any threat posed by the UXO and/or its munitions constituents. 


\section{REFERENCES}

(1) 42 USC § 9601-9628.

(2) 10 USC § 2701-2709.

(3) New-Bold Enterprises/ US Army Corps of Engineers- Huntington District 1995, G03WV006504.

(4) Human Factors Applications, Inc./US Army Corps of Engineers- Huntsville District 1999, DACA87-95-D-0019.

(5) Yinon, J. In Forensic and Environmental Detection of Explosives; John Wiley \& Sons, Ltd.: West Sussex, England, 1999; , pp 285.

(6) Jenkins, T. F.; Walsh, M. E. Talanta, 1992, 39, 419-428.

(7) Shriver-Lake, L. C.; Patterson, C. H.; van Bergen, Saskia K. Field Analytical Chemistry and Technology 2000, 4, 239.

(8) Gauger, P. R.; Holt, D. B.; Patterson, C. H.; Charles, P. T.; Shriver-Lake, L.; Kusterbeck, A. W. Journal of Hazardous Materials, 2001, 83, 51-63.

(9) Singh, S. Journal of Hazardous Materials 2007, 144, 15.

(10) Goldman, E. R.; Cohill, T. J.; Patterson, Jr., Charles H.; Anderson, G. P.; Kusterbeck, A. W.; Mauro, J. M. Environmental Science \& Technology 2003, 37, 4733.

(11) Yinon, J. TrAC Trends in Analytical Chemistry, 2002, 21, 292-301.

(12) Wang, J. In Electrochemical sensing of explosives; Yinon, J., Ed.; Counterterrorist Detection Techniques of Explosives, Elsevier Science B.V.: Amsterdam, 2007; pp 91107.

(13) Munson, C. A.; Gottfried, J. L.; De Lucia Jr., Frank C.; McNesby, K. L.; Miziolek, A. W. In Laser-based detection methods of explosives; Yinon, J., Ed.; Counterterrorist Detection Techniques of Explosives, Elsevier Science B.V.: Amsterdam, 2007; pp 279-321.

(14) Ewing, R. G.; Atkinson, D. A.; Eiceman, G. A.; Ewing, G. J. Talanta, 2001, 54, 515-529.

(15) Eiceman, G. A. TrAC Trends in Analytical Chemistry, 2002, 21, 259-275. 
(16) J. Harper, R.; G. Furton, K. In Biological detection of explosives; Jehuda Yinon, Ed.; Counterterrorist Detection Techniques of Explosives, Elsevier Science B.V.: Amsterdam, 2007; pp 395-431.

(17) Jenkins, T. F.; Hewitt, A. D.; Grant, C. L.; Thiboutot, S.; Ampleman, G.; Walsh, M. E.; Ranney, T. A.; Ramsey, C. A.; Palazzo, A. J.; Pennington, J. C. Chemosphere, 2006, 63, 1280-1290.

(18) Hewitt, A. D.; Jenkins, T. F.; Walsh, M. E.; Walsh, M. R.; Taylor, S. Chemosphere, 2005, $61,888-894$.

(19) Hewitt, A. D.; Jenkins, T. F.; Walsh, M. E.; Walsh, M. R.; Bigl, S. R.; Ramsey, C. A. 2007, ERDC/CRREL TR 07-10.

(20) Walsh, M. E.; Collins, C. M.; Ramsey, C. A.; Douglas, T. A.; Bailey, R. N.; Walsh, M. R.; Hewitt, A. D.; Clausen, J. L. 2007, ERDC/CRREL TR 07-09.

(21) United States Environmental Protection Agency- Office of Solid Waste and Emergency Response. In Method 8330B: Nitroaromatics, nitramines, and nitrate esters by high performance liquid chromatography (HPLC); Test Methods for Evaluating Solid Waste, Physical/Chemical Methods; US Environmental Protection Agency: Washington, DC, 2006; Vol. SW-846, .

(22) United States Environmental Protection Agency- Office of Solid Waste and Emergency Response. In Method 4050: TNT explosives in soil by immunoassays; Test Methods for Evaluating Solid Waste, Physical/Chemical Methods; US Environmental Protection Agency: Washington, DC, 1996; Vol. SW-846, .

(23) United States Environmental Protection Agency- Office of Solid Waste and Emergency Response. In Method 4051: Hexahydro-1,3,5-trinitro-1,3,5-triazine (RDX) in soil by immunoassay; Test Methods for Evaluating Solid Waste, Physical/Chemical Methods; US Environmental Protection Agency: Washington, DC, 1996; Vol. SW-846, .

(24) United States Environmental Protection Agency- Office of Solid Waste and Emergency Response. In Method 8515: Colorimetric screening method for trinitrotoluene (TNT) in soil; Test Methods for Evaluating Solid Waste, Physical/Chemical Methods; US Environmental Protection Agency: Washington, DC, 1996; Vol. SW-846, .

(25) United States Environmental Protection Agency- Office of Solid Waste and Emergency Response. In Method 8510: Colorimetric screening procedure for RDX and HMX in soil; 
Test Methods for Evaluating Solid Waste, Physical/Chemical Methods; US Environmental Protection Agency: Washington, DC, 2000; Vol. SW-846, .

(26) Akhavan, J. In The Chemistry of Explosives; The Royal Society of Chemistry: Cambridge, UK, 2004; , pp 180.

(27) Yinon, J. In Toxicity and Metabolism of Explosives; CRC Press: Boca Raton, FL, 1990; , pp 176.

(28) Vorbeck, C.; Lenke, H.; Fischer, P.; Spain, J. C.; Knackmuss, H. Appl Environ Microbiol 1998, 64, 246.

(29) Bradley, P. M.; Chapelle, F. H.; Landmeyer, J. E.; Schumacher, J. G. Appl Environ Microbiol 1994, 60, 2170.

(30) Seth-Smith, H. M. B.; Rosser, S. J.; Basran, A.; Travis, E. R.; Dabbs, E. R.; Nicklin, S.; Bruce, N. C. Appl Environ Microbiol 2002, 68, 4764.

(31) Binks, P. R.; Nicklin, S.; Bruce, N. C. Appl Environ Microbiol 1995, 61, 1318.

(32) Neilson, A.; Allard, A. In Environmental Degradation and Transformation of Organic Chemicals; Taylor Francis Group, LLC: Bocal Raton, FL, 2008; , pp 710.

(33) Kitts, C. L.; Cunningham, D. P.; Unkefer, P. J. Appl Environ Microbiol 1994, 60, 46084711.

(34) McCormick, N. G.; Cornell, J. H.; Kaplan, A. M. Appl Environ Microbiol 1981, 42, 817.

(35) Spanggord, R. J.; Mabey, W. R.; Chou, T.; Lee, S.; Alferness, P. L.; Tse, D. S.; Mill, T. 1983, $L S U-4412$.

(36) Hovatter, P. S.; Talmage, S. S.; Opresko, D. M.; Ross, R. H. ASTM special technical publication 1997, 117.

(37) Sunahara, G. I.; Dodard, S.; Sarrazin, M.; Paquet, L.; Ampleman, G.; Thiboutot, S.; Hawari, J.; Renoux, A. Y. Ecotoxicology and Environmental Safety 1998, 39, 185.

(38) Keith, L. H. In Environmental Sampling and Analysis- A Practical Guide; CRC PressLewis Publishers: 1991; , pp 143.

(39) Mason, B. J. 1992, EPA/600/R-92/128. 
(40) Pitard, F. F. In Pierre Gy's Sampling Theory and Sampling Practice. Volume IHeterogeneity and Sampling; CRC Press: Boca Raton, FL, 1992; Vol. 1, pp 214.

(41) Jenkins, T. F.; Hewitt, A. D.; Walsh, M. E.; Ranney, T. A.; Ramsey, C. A.; Grant, C. L.; Bjella, K. L. Environmental Forensics 2005, 6, 45.

(42) Walsh, M. E.; Collins, C., M.; Douglas, T. A.; Hewitt, A. D.; Walsh, M. R.; Bailey, R. N.; Clausen, J. L. 2007, ERDC/CRREL TR 07-09.

(43) Jenkins, T. F.; Grant, C. L.; Brar, G. S.; Thorne, P. G.; Schumacher, P. W.; Ranney, T. A. Field Analytical Chemistry and Technology 19971, 151. 


\section{Appendix A. Standard Operating Procedure - Soil Sampling}

\section{SOP- Soil Sampling}

\section{General:}

- No sampling is to commence unless or until the UXO safety personnel have checked and cleared the site to a depth of at least 8 inches.

- If any foreign or suspected objects or materials are encountered, immediately stop work and notify safety personnel. Keep the area secured until cleared.

- All project related items packed into wilderness area will be collected at the end of each day and packed out of the wilderness area.

- All sampling areas must be restored as closely as possible to pre-disturbance condition.

- Soil science samples: At least 2 L of composite soil should be collected from each grid.

\section{Specific procedure:}

1) Select grid location.

2) Obtain the GPS coordinates for the centre of each cell. Record on the sample log sheet.

3) Mark 9' x 9' grid area using a PVC pipe frames, or mark $3 \mathrm{~m}$ x $3 \mathrm{~m}$ grid area using tape measure and stakes, cordon area using string. Once grid is cordoned, place markers at the top left and bottom right corners of the grid.

4) Photograph grid form different perspectives and complete a data sheet: outline grid features including any obstructions e.g. rocks/plant life. Remaining outside of the grid, record the GPS coordinates of the flagged corners.

5) While sampling, work from the outside of the grid to the inside. Do not step on grids that have not been sampled.

6) For each cell:

a. Within one cell carefully remove the top layer of soil or debris with a pre-cleaned shovel. Retain a sample of this material in a $60 \mathrm{~mL}$ glass sample jar. Secure cap tightly and label using prepared label sheets.

b. Clean shovel: away from grid area shake off loose debris. Rinse once with water and once with D.I. water/acetone. Use a funnel to collect waste D.I water/acetone in a rinse collection jar, secure cap tightly and complete and attach a label.

c. Using a pre-cleaned shovel remove and discard a thin layer of soil from the area which came into contact with the shovel. Collect $2 \times 10 \mathrm{~g}$ samples, place each in a separate $250 \mathrm{~mL}$ cups and retain. Clean shovel as outlined above. 
d. Using a pre-cleaned scoop obtain $\sim 20-50 \mathrm{~g}$ soil sample from as close to center of the cell as feasible. Transfer sample into a glass jar and secure cap tightly. Complete and attach a sample label. Complete sample log sheet. Collect 2 x $10 \mathrm{~g}$ samples, place each in the previous $250 \mathrm{~mL}$ cups and retain. Clean scoop as outlined above.

7) Complete steps a - $\mathrm{d}$ for each grid cell. Carefully clean appropriate utensils between cells. Note: for each cell use the same rinse collection jar to give a composite mixture for the grid.

8) Make composite sample: combine one set of $250 \mathrm{~mL}$ cup soil samples in a plastic bag. Securely seal, label and store out of sunlight. Record data in log sheet.

9) Collect a core sample. Insert a pre-cleaned liner into the core sampler, attach top bolt and tshaped handle. Remove t-shaped handle and top bolt and place a cap over the liner. Remove liner and cap the open end. Complete sample label and attach to liner. Complete sample log sheet. Repeat this procedure in four random cells. Collect composite core samples for soil science: within each cell, use corer to collect soil samples which will be added to the previous cell cup such that the total volume is $250 \mathrm{~mL}$. The same volume of soil should be collected from each cell such that the total volume collected from each grid is at least 2L. Soils collected from each cell should be combined in a large bag. Bags should be labeled with the grid number and placed out of direct sunlight. If one or more cells from each grid can not be sampled, the number of cores from the sampled cells must be adjusted so as to give a total volume of at least 2L per grid.

10) Wash appropriate utensils using the procedure outlined in step 5. Wrap cleaned utensils in aluminum foil and store.

Reference: U.S. EPA SOP 2012 Soil Sampling, 2000 


\section{Appendix B. Standard Operating Procedure- Mechanical Grinding of Soil Samples SOP - Mechanical Grinding of Soil Samples Using an SPEX Shatterbox 8510}

1. Safety wear should be used for this procedure. Gloves and goggles used throughout and a respirator while carrying out step 9.

2. Cover surfaces to be used with paper.

3. Clean grinder parts that will come into contact with soil samples: grinder dish, puck, rubber gasket, lid and spatula. Clean thoroughly with dilute Micro 90 soap then rinse with tap water, D.I. water and finally acetone. Dry in oven. Take caution when removing parts from oven as they will be very hot!

4. Place puck inside of grinder dish, placing it to one side. Place a small amount of soil into the dish pouring soil beside the puck in a cone shape. Place rubber gasket and then lid onto grinder dish.

5. Place filled dishes onto grinder disk and cover with clamp disk (rubber side should face down). Clamp ensuring that bolt is tightened using wrench. Cover with grinder lid.

6. Turn timer to maximum position to begin grinding.

7. Once grinding is complete remove lid and unlock clamp bolt.

8. Make sure correct safety wear is in place prior to opening grinder dishes (respirator, gloves and goggles).

9. Place grinder dish onto a paper covered surface. Remove lid carefully. Remove puck from dish transferring any sample sticking to puck into an appropriately labeled plastic bag. Onto a clean piece of paper carefully invert dish upside down. Tap base of dish to remove any sample sticking to the base. Lift dish slowly. Remove any remaining sample with a spatula. Carefully transfer the sample from the paper into the appropriate plastic bag. Seal bag.

10. Samples may need to be split into small amounts for grinding. If this is the case it is not necessary to clean grinder parts while working with the same sample, repeat steps 4-10.

11. When grinding is complete or when a new sample is to be ground clean grinder parts as described in step 3. When grinding is complete store cleaned parts in oven. 


\title{
Appendix C. Standard Operating Procedure - Extraction
}

\section{$\underline{\text { SOP - Extraction }}$}

\author{
Extracting Nitroaromatics/Nitroamines from Soil \\ Using an Orbital Shaker (EPA 8330b)
}

1. Obtain a bag containing the soil you want to extract.

2. Shake bag carefully in order to mix soil.

3. Open the bag and empty the soil onto a sheet of foil.

4. Using a spatula, spread soil out into an even layer (about $1 / 2$ inches thick).

5. Take increments of soil using a spatula in a similar manner to the CRREL multi-increment method.

a. Place jar/flask on balance.

b. Take 30 individual multi-increment samples, all evenly spaced apart. Collect all soil in the selected area, down to the level of the aluminum foil (Note: Care should be taken not to tear foil). Place all increments into a jar/flask and weigh.

c. In order to achieve a total of $10 \mathrm{~g}$ after 30 increments, try to obtain $\sim 0.3 \mathrm{~g}$ per increment. Weigh final amount and record in extraction $\log$ book (final weight needs to be around $10 \mathrm{~g}$ ).

6. Add $20 \mathrm{~mL}$ of acetonitrile to the jar/flask. Cap.

7. Place on orbital shaker and shake at $150 \mathrm{rpm}$ for $18 \mathrm{hrs}$.

8. Log date and time in the extraction log book.

9. Remove jar/flask from orbital shaker after $18 \mathrm{hrs.}$

10. Let jar/flask sit for $30 \mathrm{~min}$ in order for the particulate to settle.

11. Pipette $9 \mathrm{~mL}$ of the top solution into a glass syringe and filter the solution through a $0.45 \mu \mathrm{m}$ PTFE filter. Discard the first $\mathrm{mL}$. Collect the rest into a vial.

12. Split the solution from Step 11: $2 \mathrm{~mL}$ for GC-ECD, $2 \mathrm{~mL}$ for GC-MS, $2 \mathrm{~mL}$ for IMS and $2 \mathrm{~mL}$ for HPLC. Store all solution in the freezer.

a. HPLC Preparation: Pipette $500 \mu \mathrm{L}$ from the $2 \mathrm{~mL}$ solution and dilute with $1.5 \mathrm{~mL}$ of the mobile phase. 


\section{Appendix D. Representative Field Notes and Data Sheets}

Grid Data Sheet: Page 1 of 8

GRID IDENTIFIER:

DATE SAMPLED:

PERSON(s) SAMPLING:

Complete the grid below. Use an arrow to indicate the direction of North. The top left corner (Grid Cell A) should be defined as laid out in the SOP. Provide the GPS coordinates of the upper left and lower right grid comers. If extra labels are used, record labels and notes on the back of the page.

\begin{tabular}{|c|c|c|}
\hline & B & C \\
& & \\
\hline D & E & F \\
\hline & & \\
\hline G & H & \\
\hline & & \\
\hline
\end{tabular}

Symbols:

$\square$ Rock
$\bigcirc$ Tree
$\triangle$ Other: specify

Figure 43- Sample field data sheet 
PERSON(s) SAMPLING: Lucy, walt

Complete the grid below. Use an arrow to indicate the direction of North. The top left corner (Grid Cell A) should be defined as laid out in the SOP. Provide the GPS coordinates of the upper left and lower right grid corners. If extra labels are used, record labels and notes on the back of the page.

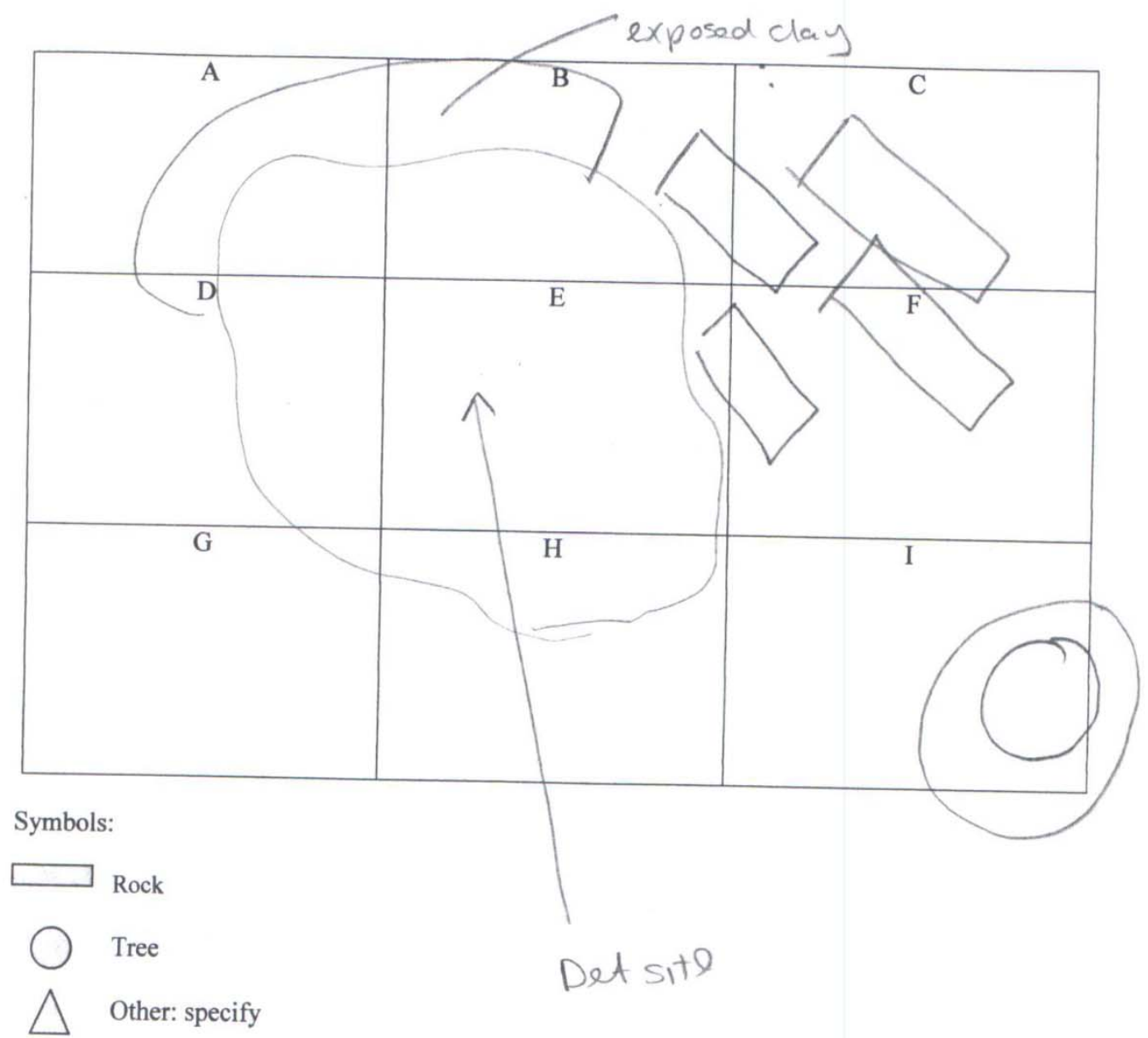

Figure 44- Field data sheet from Grid XD 
Grid Data Sheet: Page 2 of 8

GRID IDENTIFIER: $\frac{X \text {-Det }}{\text { DATE SAMPLED: } 08 / 21 / 07}$
PERSON(s) SAMPLING: Lucy, walt

Notes:

(Comment on soil consistency, color, condition (wet/dry) and if there are organisms present.)

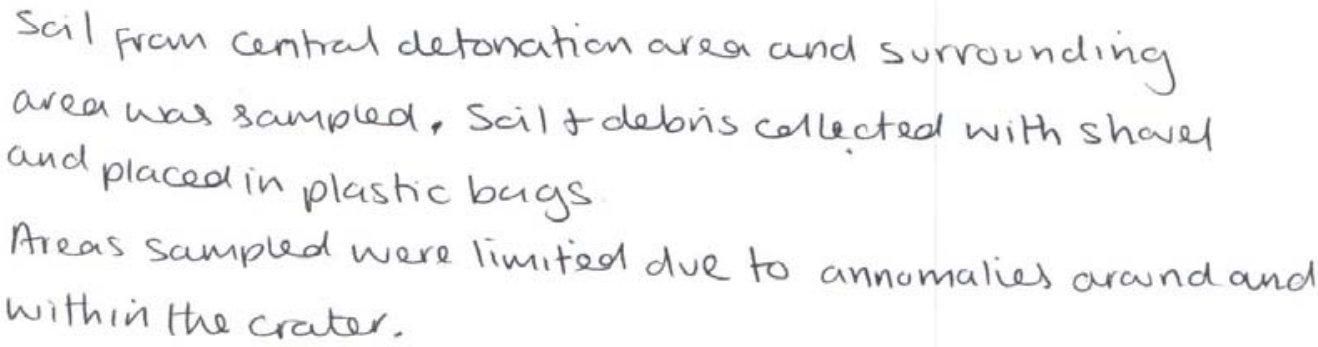

Figure 45- Field data sheet from Grid XD 
GRID IDENTIFIER: $\quad x$ - Det DATE SAMPLED: $08 / 21 / 07$

PERSON(s) SAMPLING: Lucy, walt

\begin{tabular}{|c|c|}
\hline SAMPLE LABELS USED: & NOTES: \\
\hline WVu-2007-xD-1 & $\begin{array}{l}\text { Detonation centre. } \\
\text { taken on and around rocks } \\
\text { within crater. }\end{array}$ \\
\hline WVU-2007-XD - 2 & $\begin{array}{l}\text { taken from left of detonation } \\
\text { crater. (down slope, boltom) }\end{array}$ \\
\hline$w v v-2007-x D-3 a$ & $\begin{array}{l}\text { taken frem back of detonation } \\
\text { crater (up-slope). Soils surface } \\
\text { uncavereds, clays exposed }\end{array}$ \\
\hline wru $-2007-x D-36$ & Same as above \\
\hline$\omega v v-2007-X 0-4$ & $\begin{array}{l}\text { Taken from area below detonation } \\
\text { crater, heading dewn slope. }\end{array}$ \\
\hline . & \\
\hline
\end{tabular}


Figure 46- Field data sheet from Grid XD

Grid Data Sheet: Page 1 of 8

GRID IDENTIFIER: $\quad 20$

DATE SAMPLED: $\quad 8 / 23 / 07$

PERSON(s) SAMPLING: Mel

Complete the grid below. Use an arrow to indicate the direction of North. The top left corner (Grid Cell A) should be defined as laid out in the SOP. Provide the GPS coordinates of the upper left and lower right grid comers. If extra labels are used, record labels and notes on the back of the page.

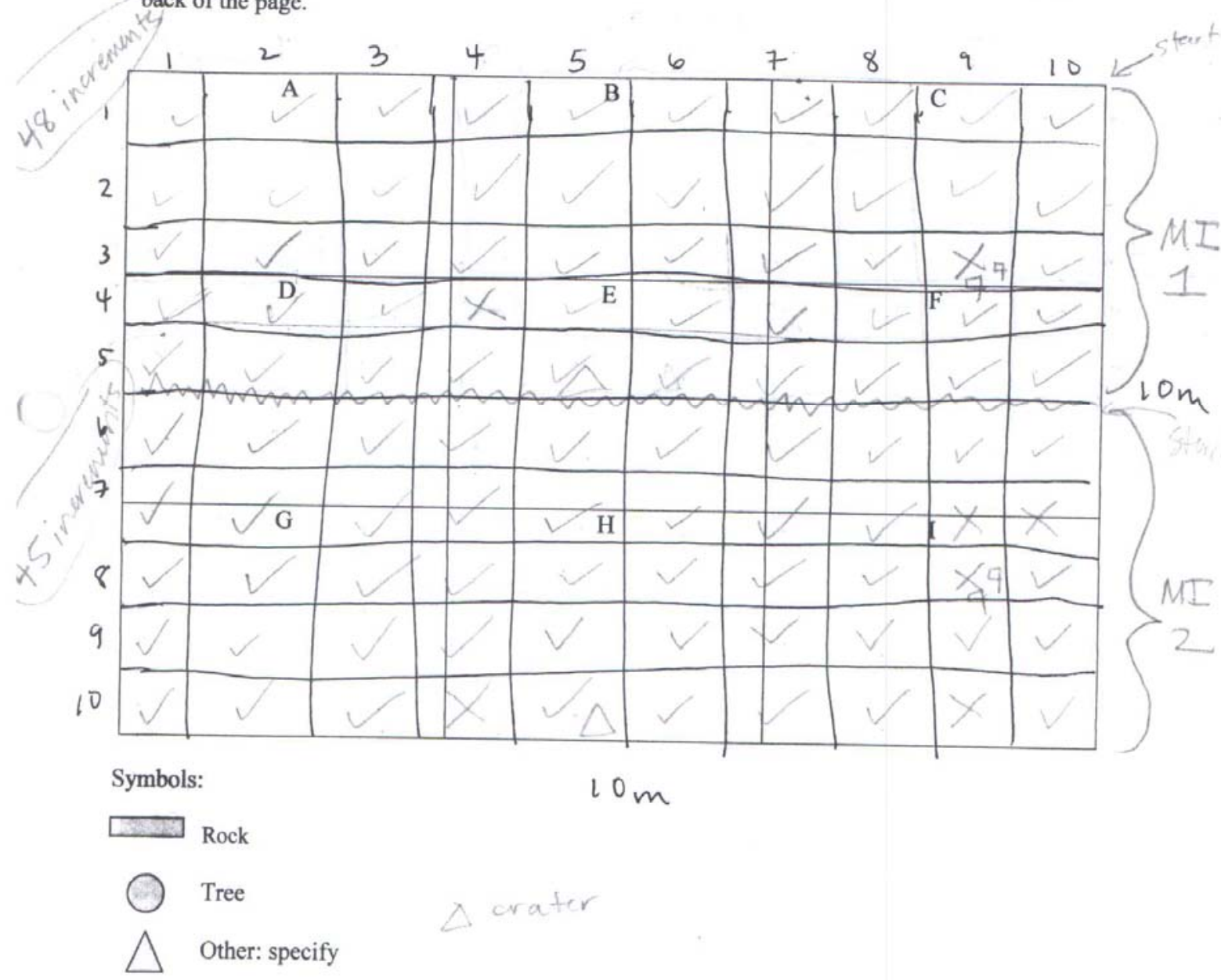

$10 \times 5 m$

Figure 47- Field data sheet from Grid 20 


$$
\begin{aligned}
& \text { GRID } 20 \\
& \text { MI-3 (triplicate) }
\end{aligned}
$$

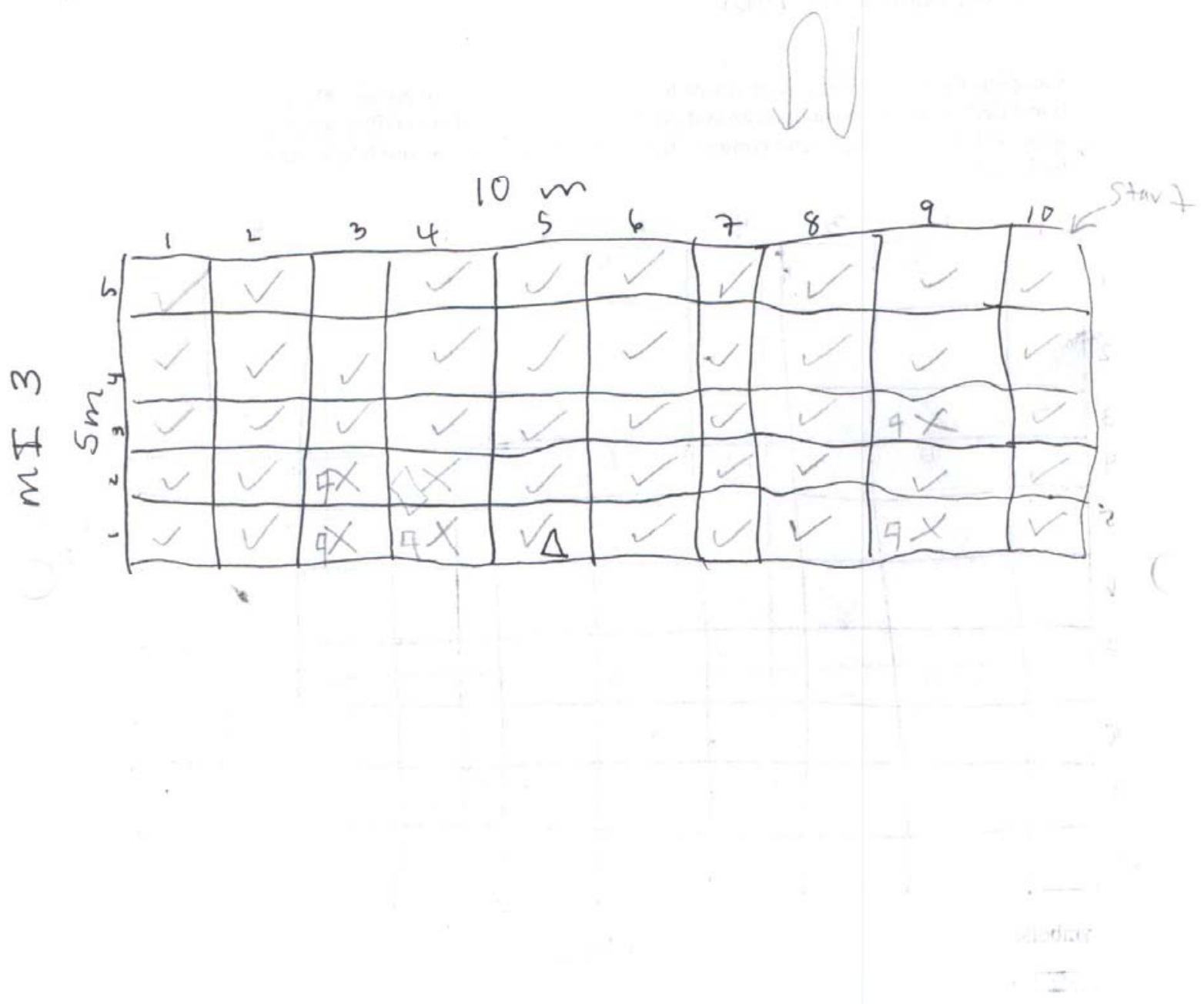

Figure 48- Field data sheet from Grid 20 
Grid Data Sheet: Page 2 of 8

GRID IDENTIFIER: 20

DATE SAMPLED: $\quad 8 / 23 / 07$

PERSON(s) SAMPLING: $\quad$ M

Notes:

(Comment on soil consistency, color, condition (wet/dry) and if there are organisms present.)

- White particles of $\mathrm{Cy}$ were visible around crater

- area immediately behind crater was too contaminated (per Walt's "imaging" analysis) and densely vegetated to sample

- creel cover used

- large area of grid not sampled due to the contamination and vegetation

- $80 \mathrm{~mm}$ rocket blow in place

- practice rocket

- detonated with C4 in Dec 2006

- In $x$ In area staked around crater and depth profiles taken with carmen's cover in pattern to
left
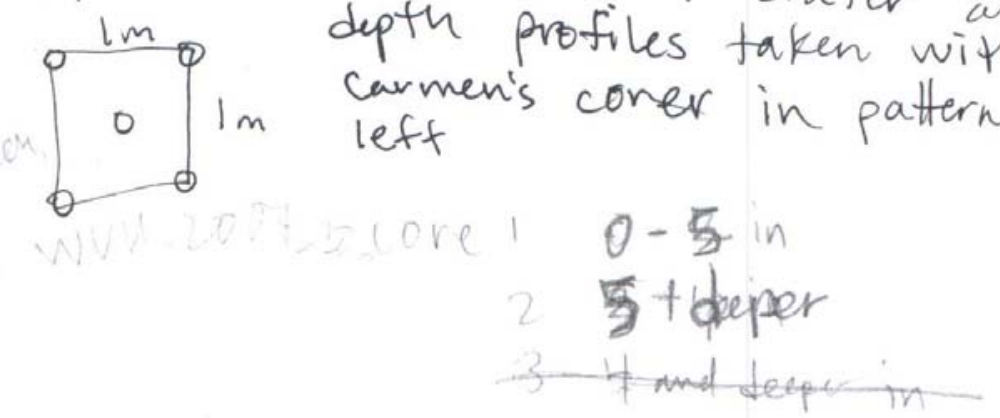

Figure 49- Field data sheet from Grid 20

62 
Grid Data Sheet: Page 3 of 8

GRID IDENTIFIER: 20 DATE SAMPLED: $8 / 23 / 07$
PERSON(s) SAMPLING: Mel + LuCy

\begin{tabular}{|c|c|}
\hline SAMPLE LABELS USED: & NOTES: \\
\hline$W V U-2007-20-M I-3$ & $\begin{array}{l}\text { CVI \#2 } \\
3^{\text {rd }} \text { composite sample fremitiplicate } \\
\Rightarrow \text { EPA cover. }\end{array}$ \\
\hline WVU $-2007-20-M \hat{I}-2$ & $\begin{array}{l}\text { CuI\#2. } \\
2^{\text {nd }} \text { comp sample }\end{array}$ \\
\hline WVU -2007-20-MI-1 & $\begin{array}{l}C_{V I H Z} \\
\text { st }^{\text {st }} \text { comp sample }\end{array}$ \\
\hline WVU-2007-20-CORE-1 & $\begin{array}{l}\text { Core composite. } \\
\text { top layer } 4 "\end{array}$ \\
\hline$W V U-2007-20$-COKG-2 & $\begin{array}{l}\text { cave comp } \\
\text { laver layer >4" }\end{array}$ \\
\hline WUU-2007-20-GRALS & $\begin{array}{l}\text { Crater surface. } \\
\text { Hazard } \mathrm{C}_{4} \text { Hazard }\end{array}$ \\
\hline
\end{tabular}

Figure 50- Field data sheet from Grid 20 
Appendix E. Representative Chromatograms from Preliminary Soil Analysis by HPLC-UV (utilizing Dionex Acclaims E2 Column)

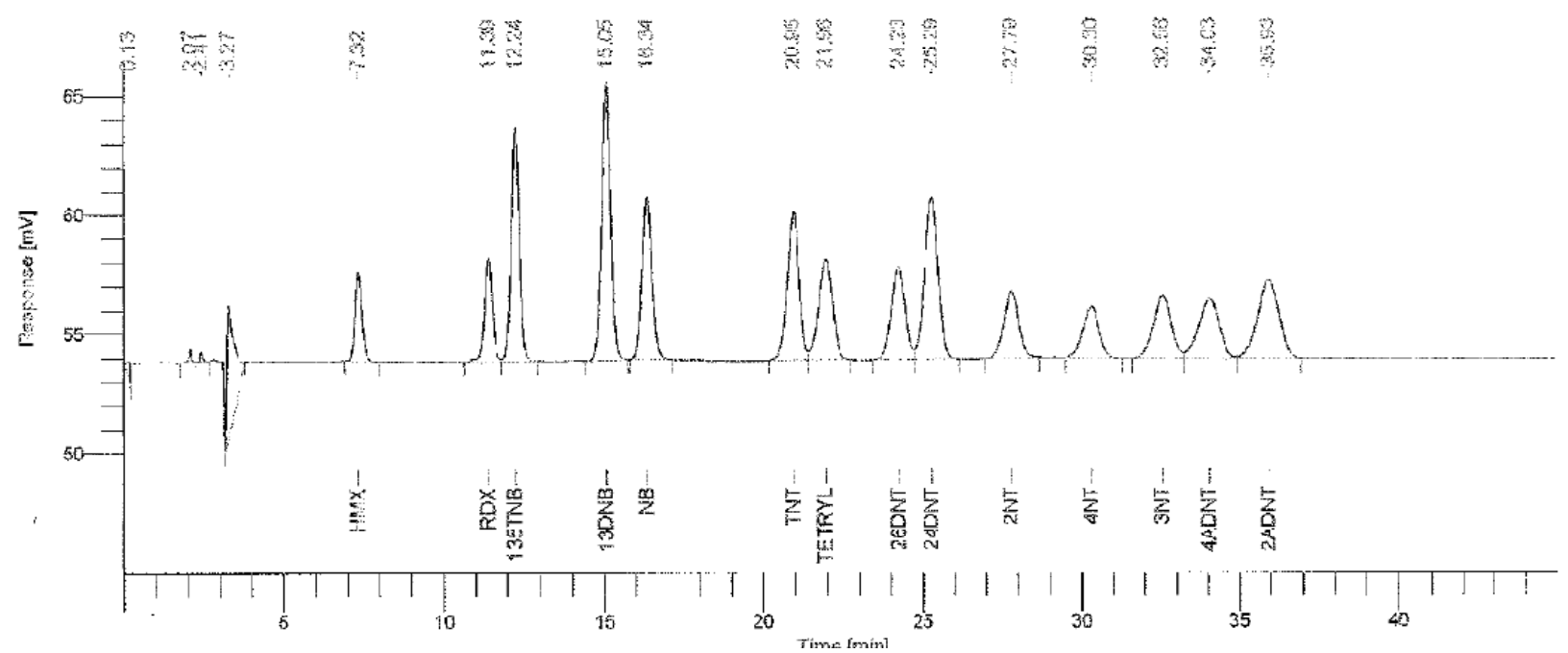

Figure 51- Representative HPLC-UV chromatogram from analysis of 500ppb calibration standard

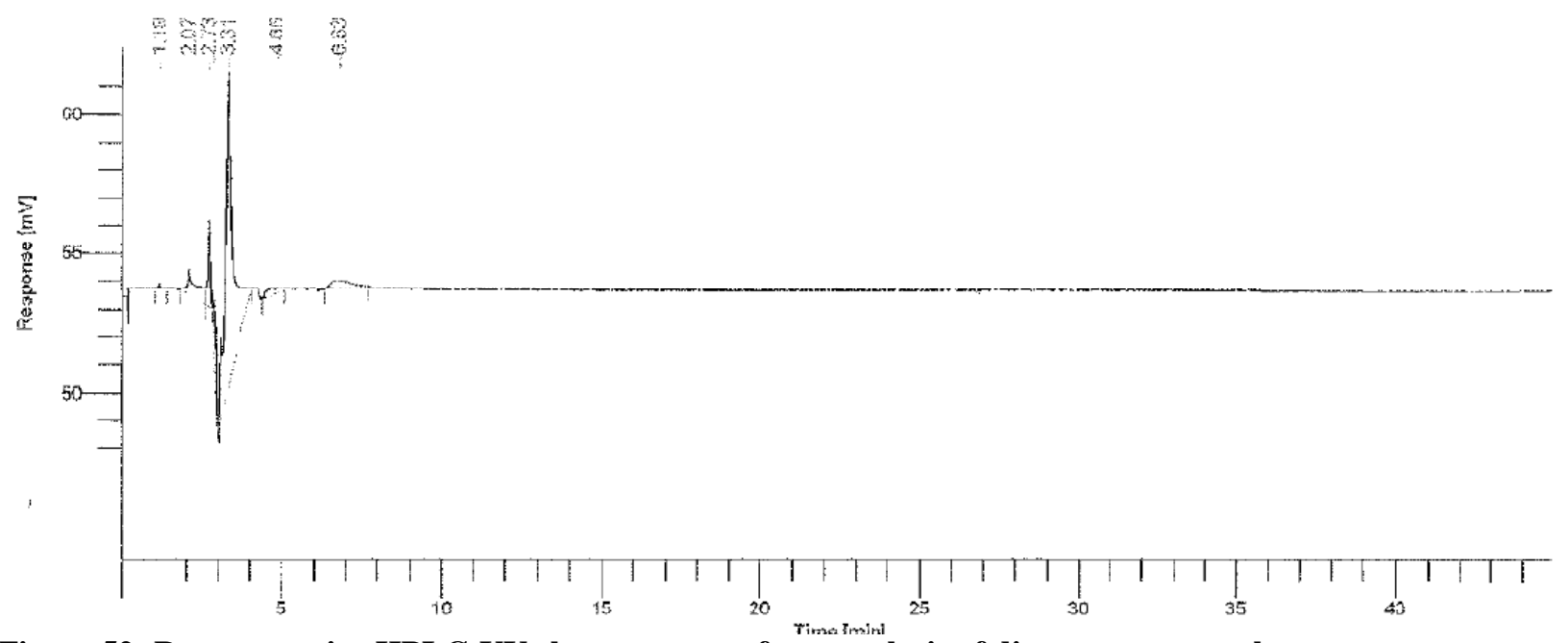

Figure 52- Representative HPLC-UV chromatogram from analysis of diatomaceous earth 


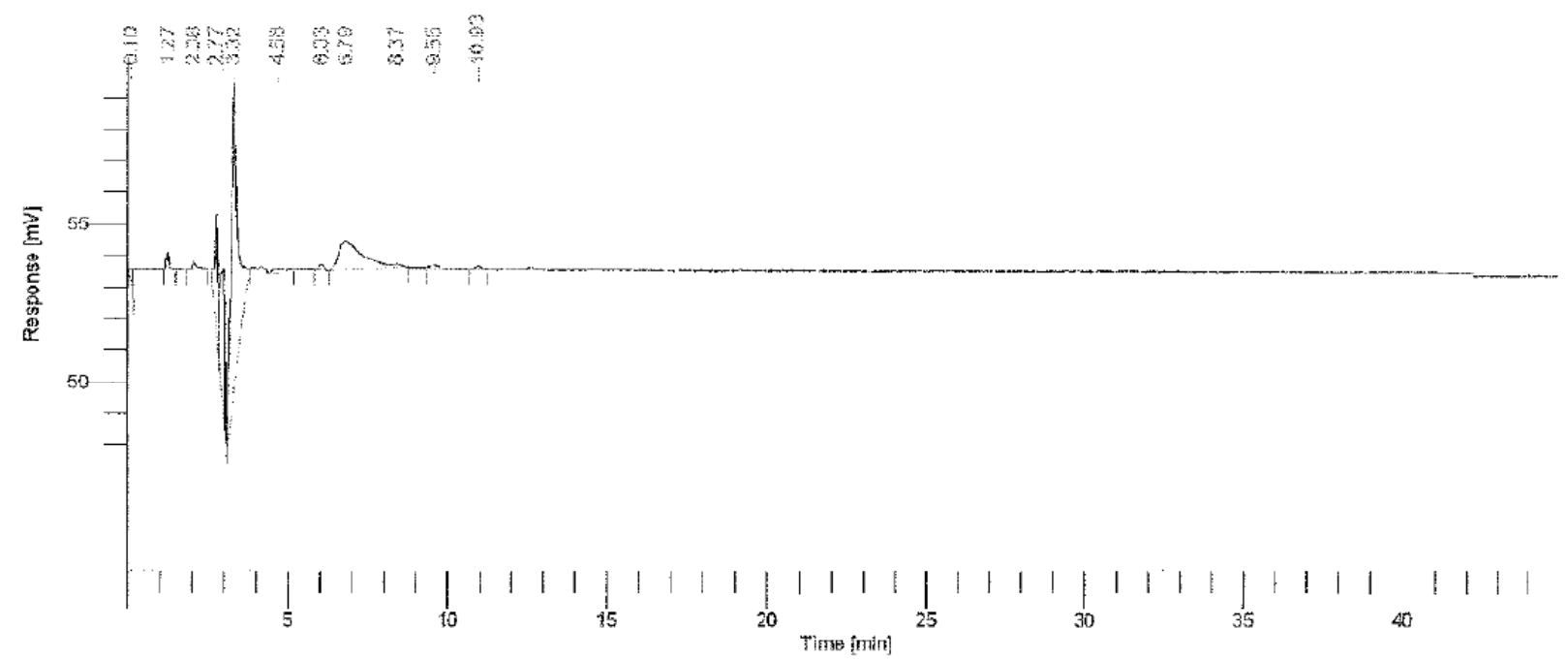

Figure 53- Representative HPLC-UV chromatogram from analysis of blank soil

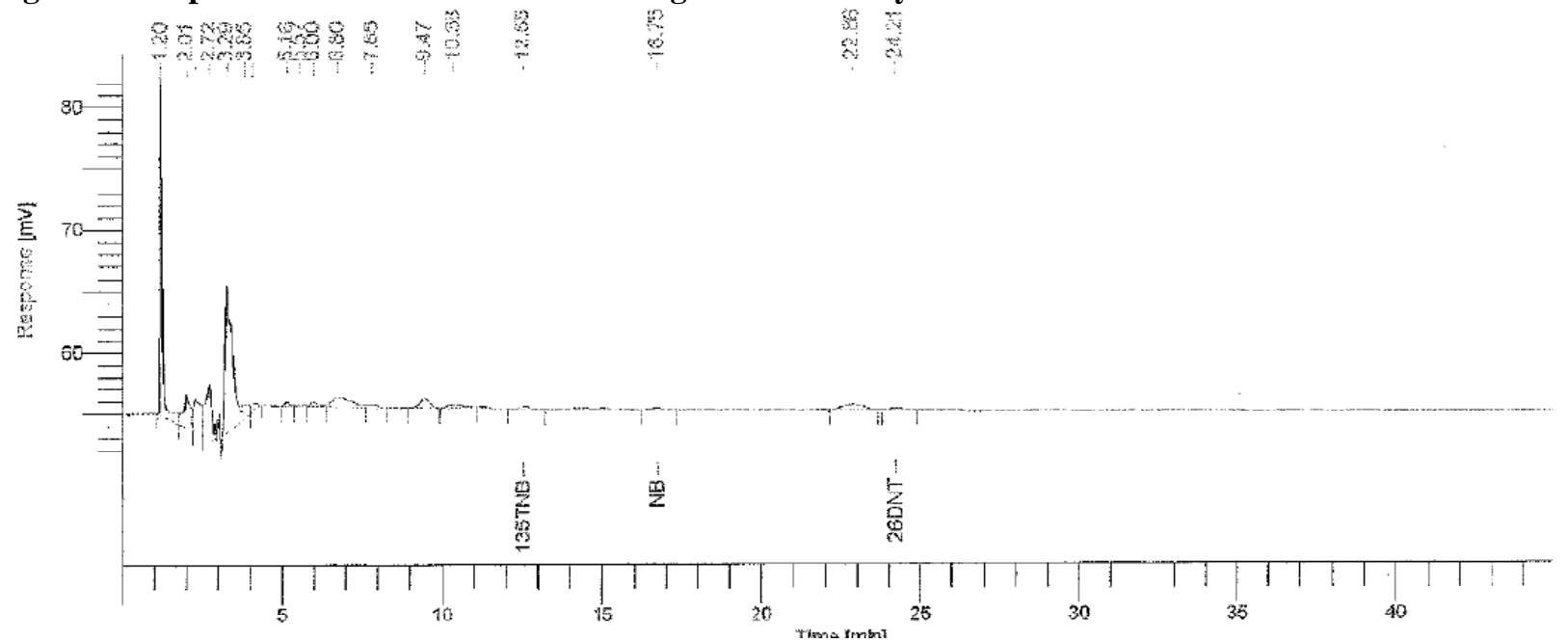

Figure 54- Representative HPLC-UV chromatogram from analyis of sample WVU_2007_14_MI_1

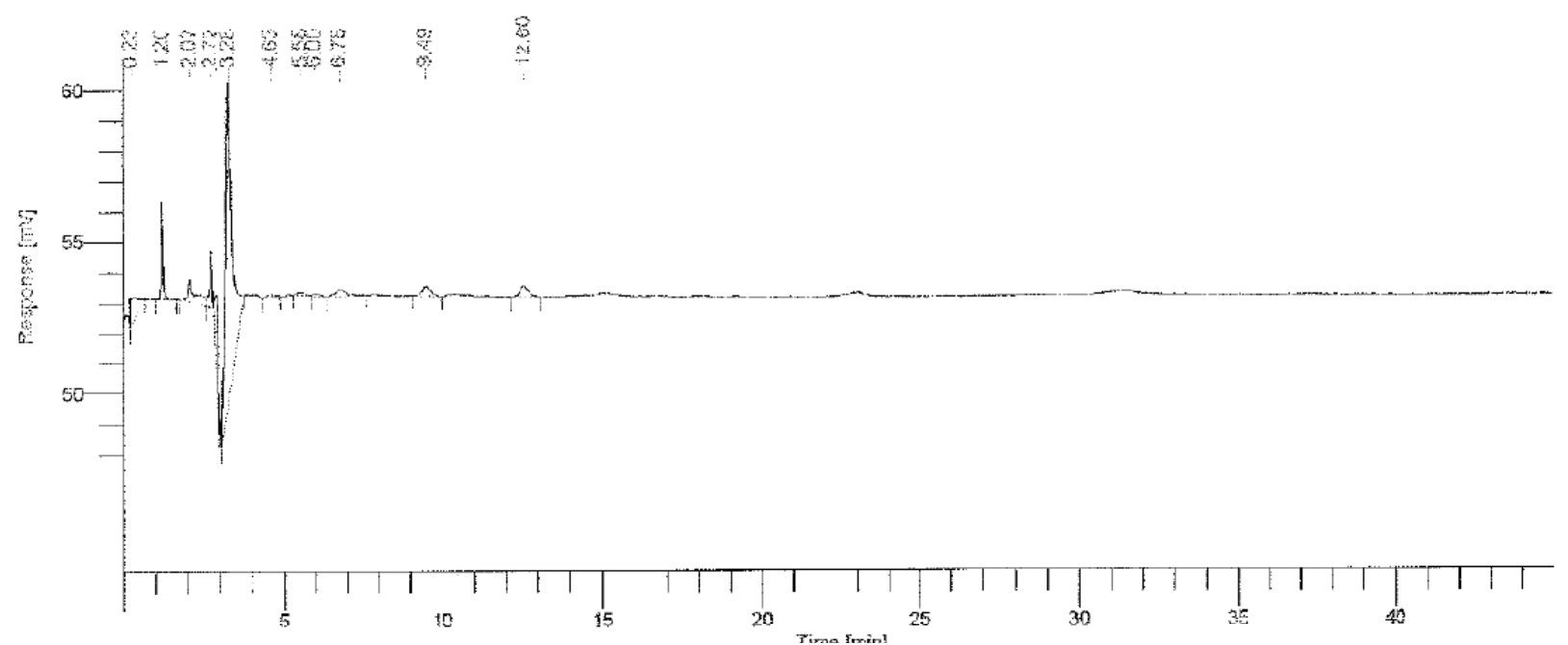

Figure 55- Representative HPLC-UV chromatogram from analysis of sample WVU_2007_14_CORE_1a 


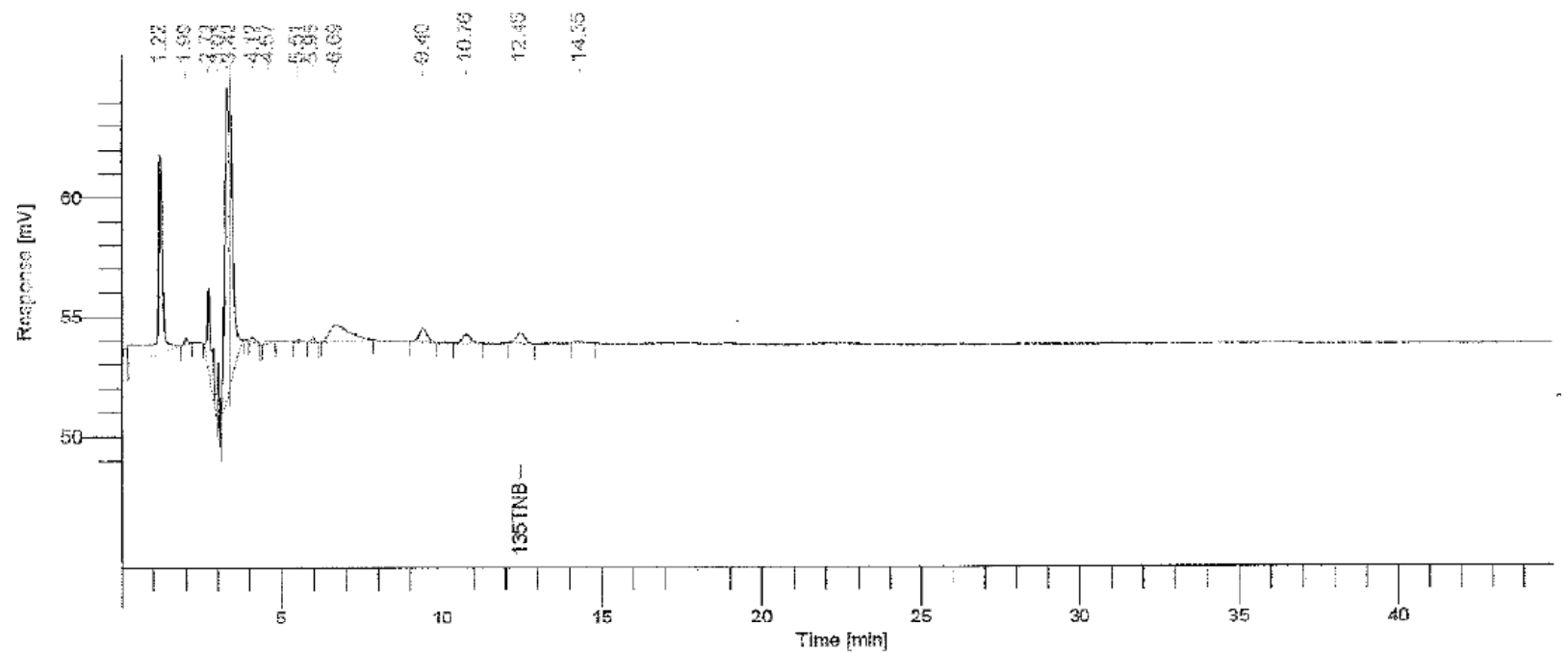

Figure 56- Representative HPLC-UV chromatogram from analysis of sample WVU_2007_14_CORE_1b

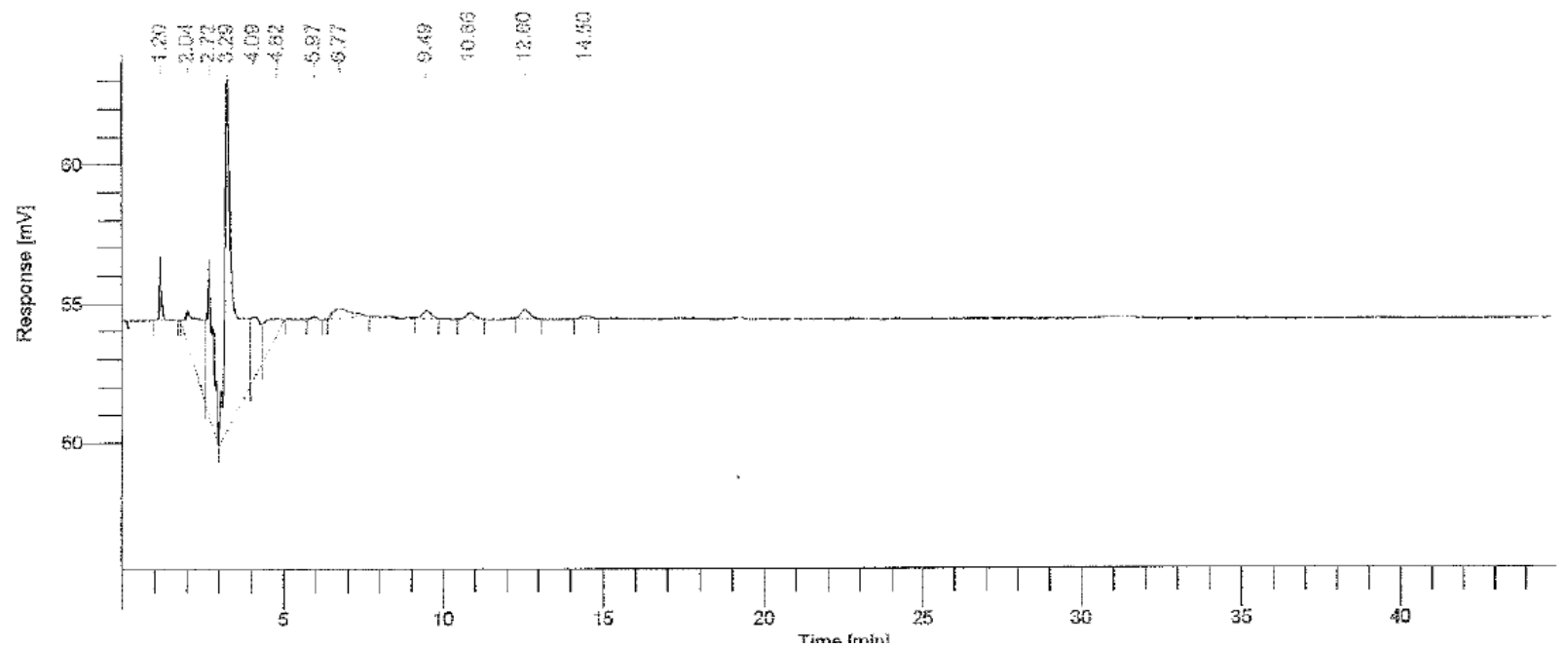

Figure 57- Representative HPLC-UV chromatogram from analysis of sample WVU_2007_14_CORE_1c

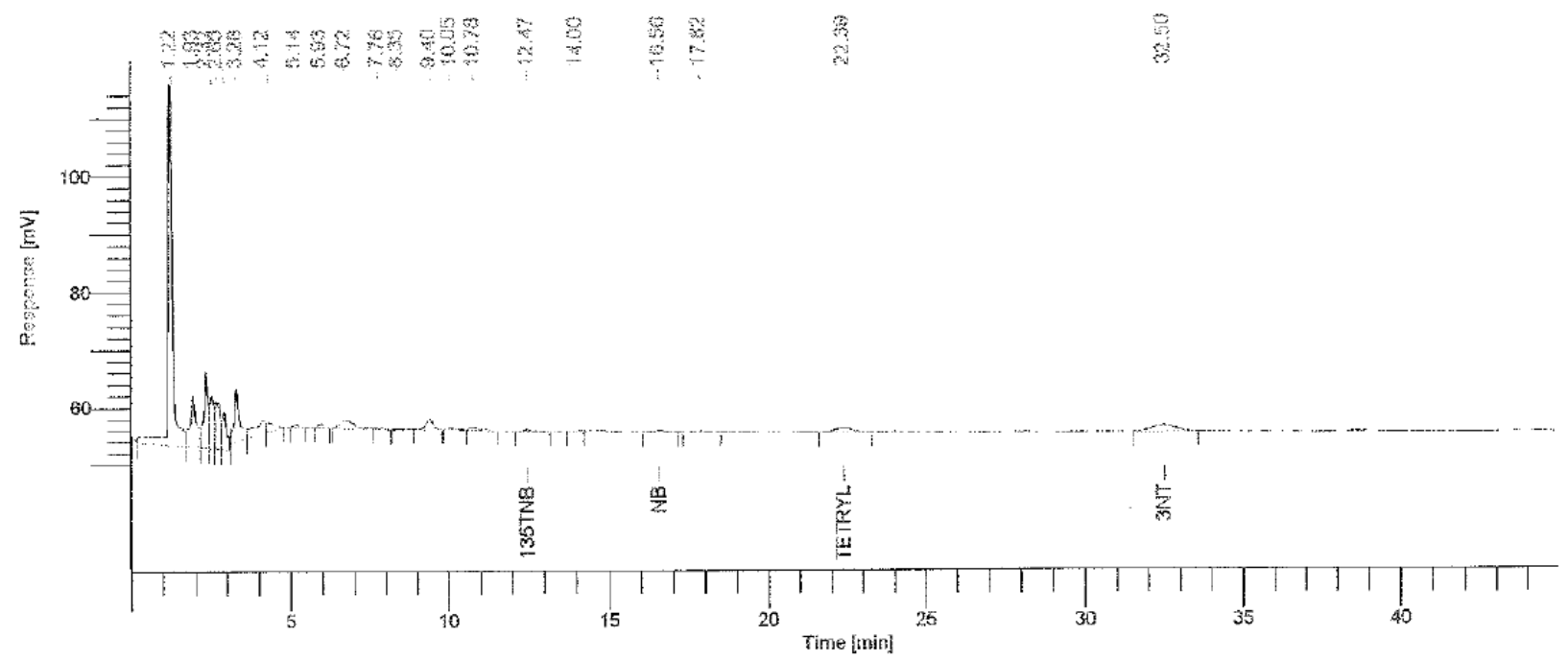

Figure 58- Representative HPLC-UV chromatogram from analysis of sample WVU_2007_15_MI_1 


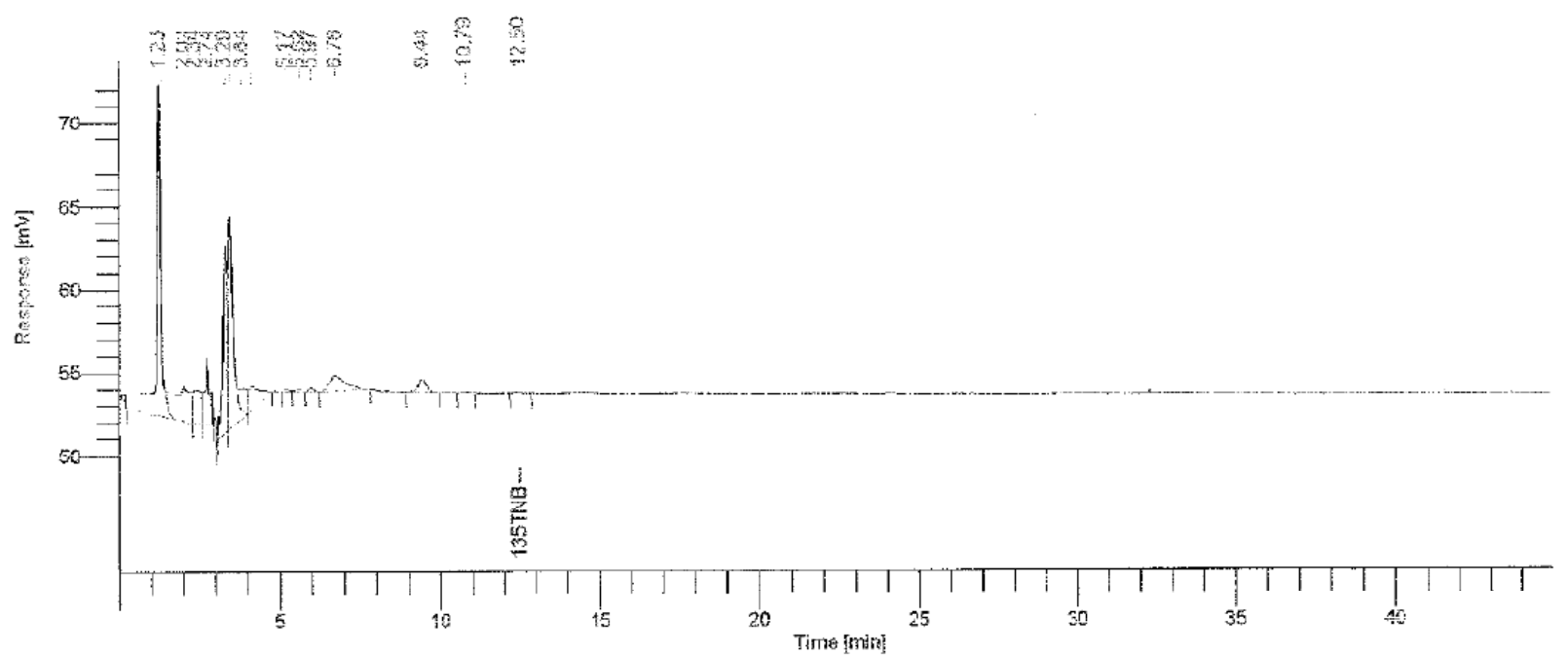

Figure 59- Representative HPLC-UV chromatogram from analysis of sample WVU_2007_16_GRAB

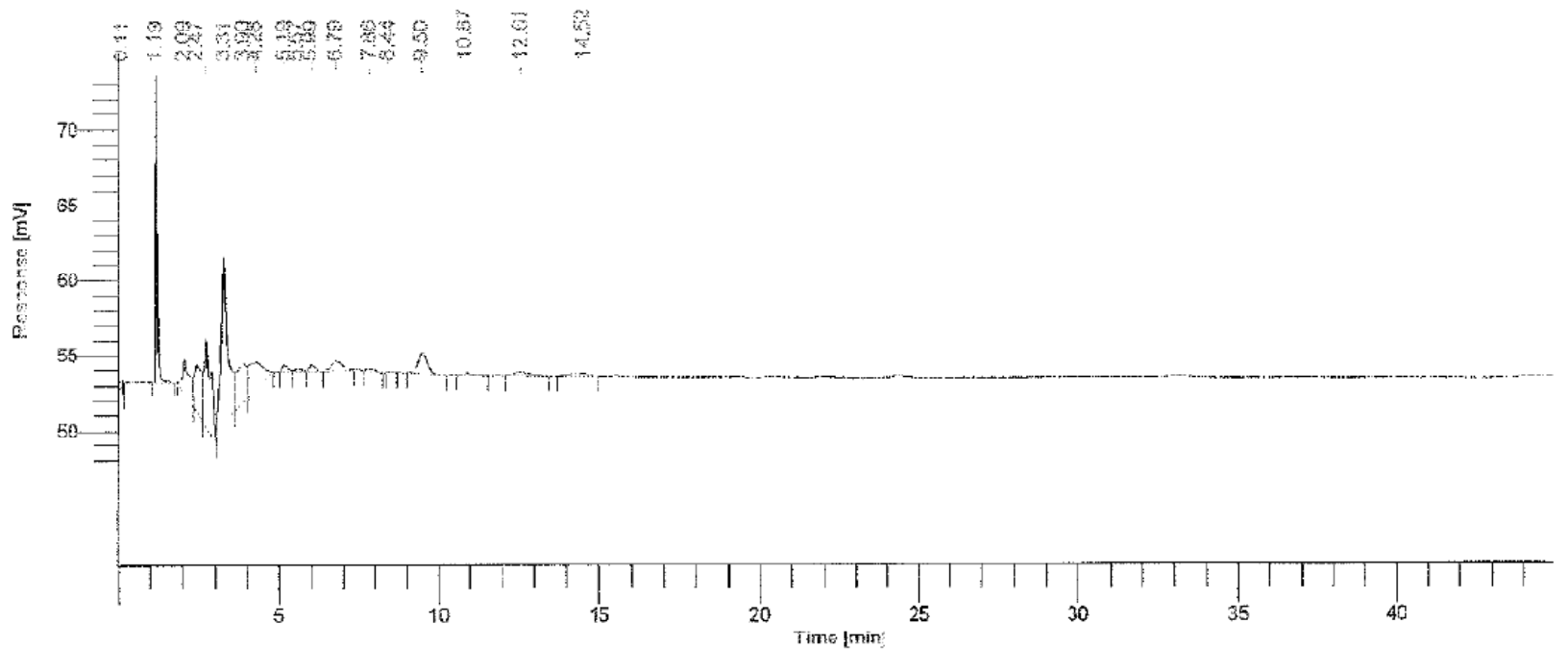

Figure 60- Representative HPLC-UV chromatogram from analysis of sample WVU_2007_16_MI_1

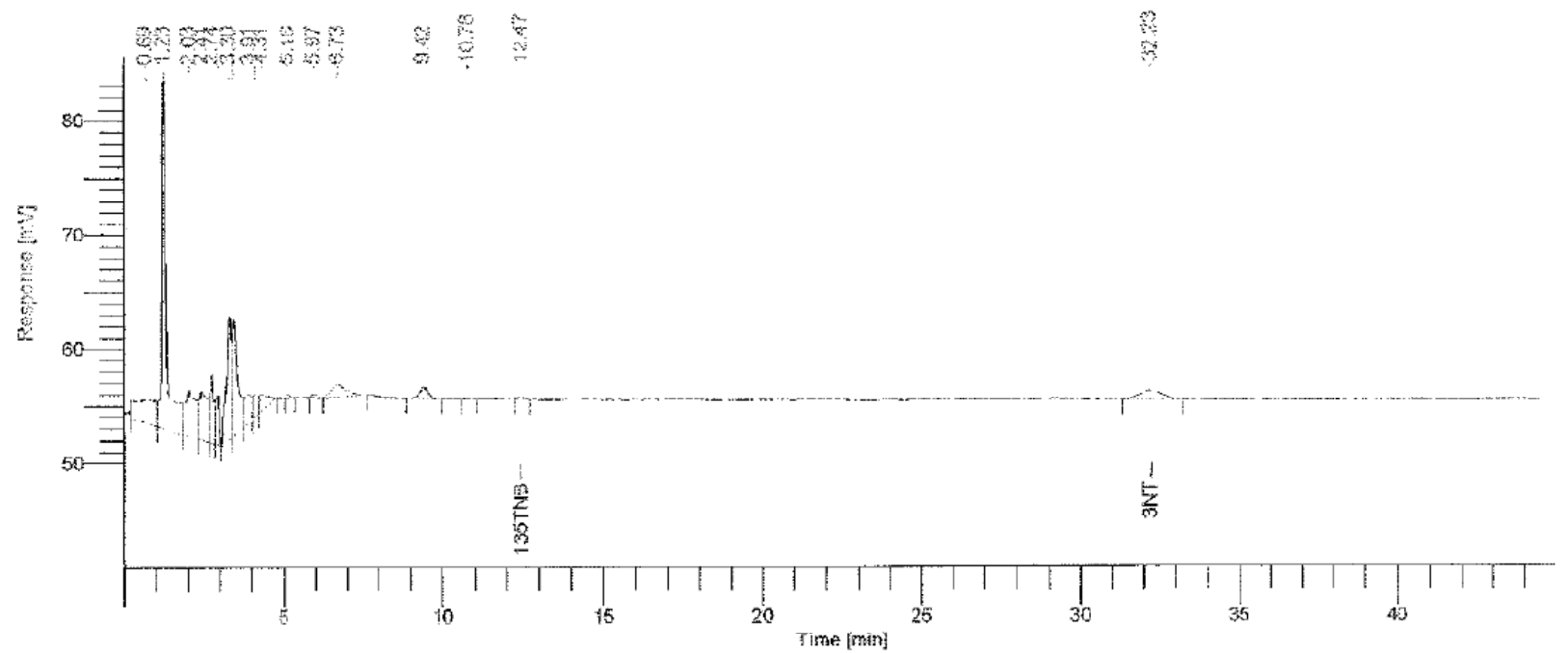

Figure 61- Representative HPLC-UV chromatogram from analysis of sample WVU_2007_16_MI_2 


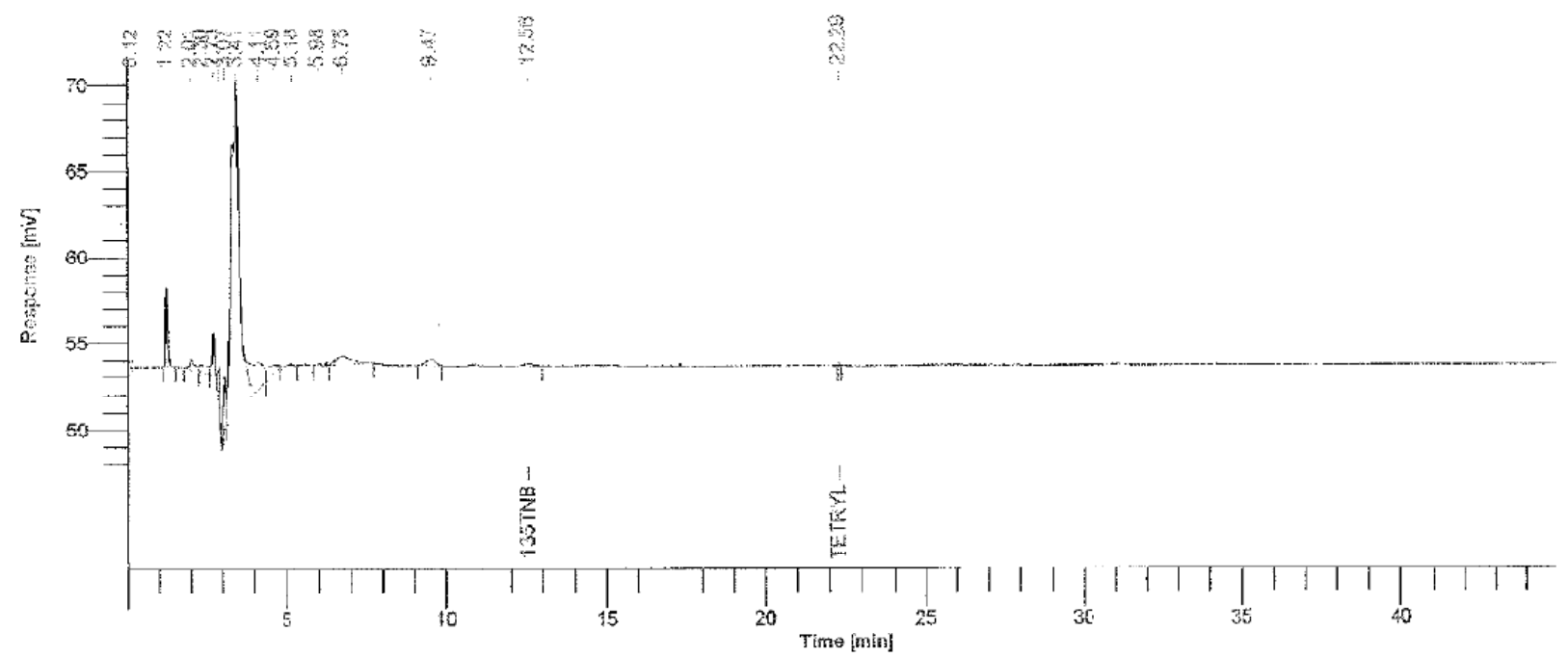

Figure 62- Representative HPLC-UV chromatogram from analysis of sample WVU_2007_16b_MI

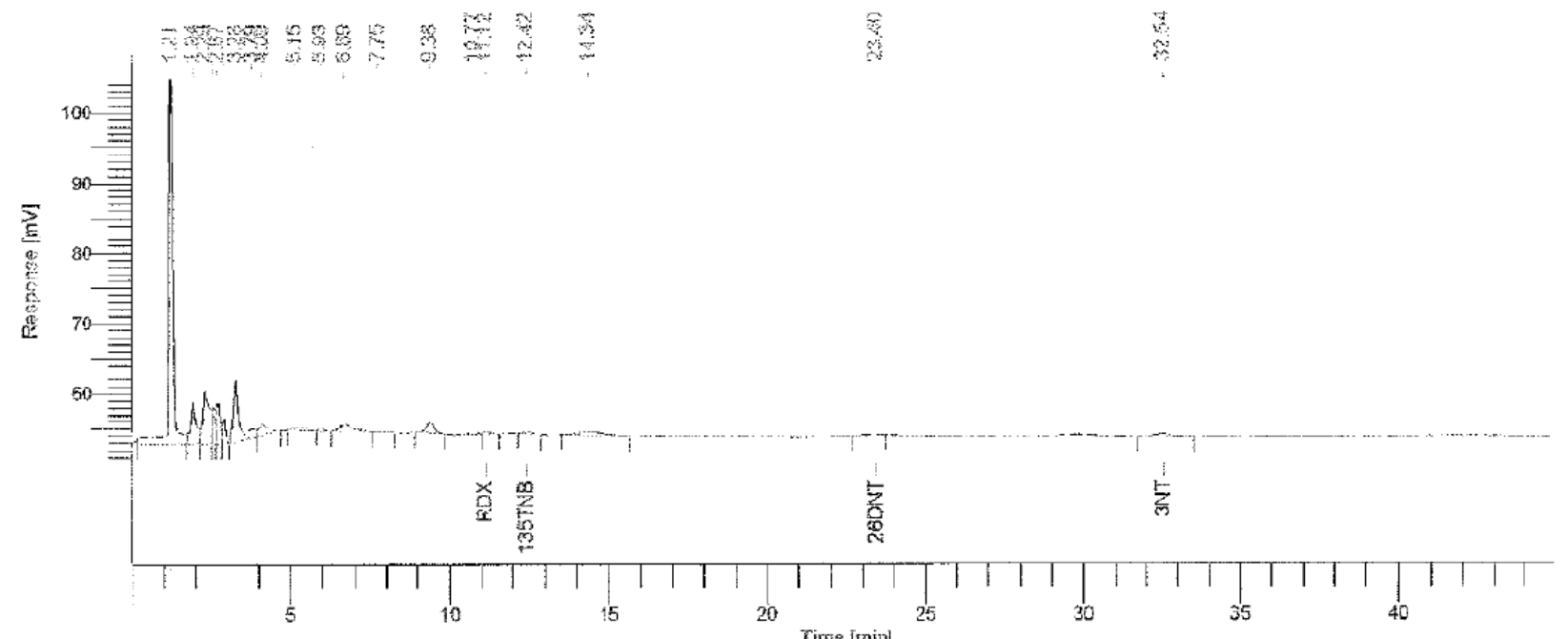

Figure 63- Representative HPLC-UV chromatogram from analysis of sample WVU_2007_19_GRAB

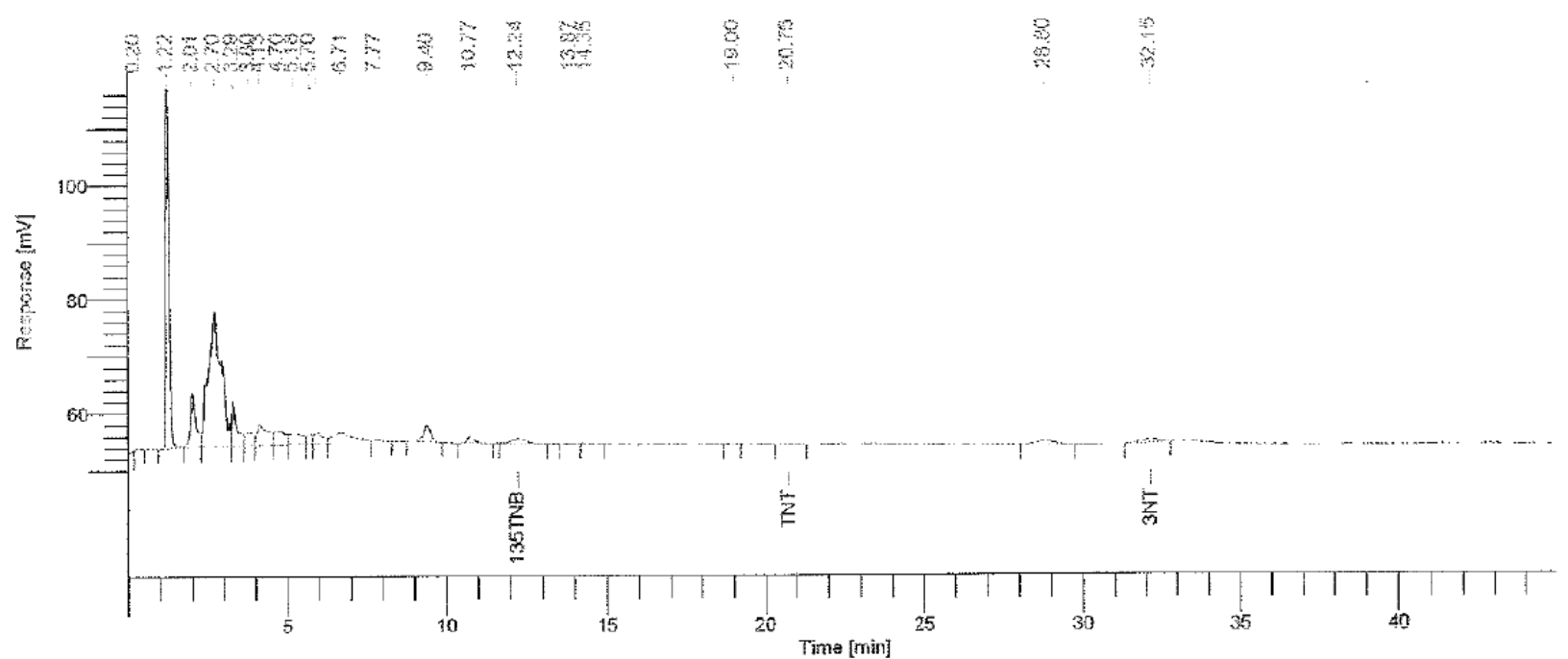

Figure 64- HPLC-UV chromatogram from analysis of sample WVU_2007_19_MI (first run in triplicate) 


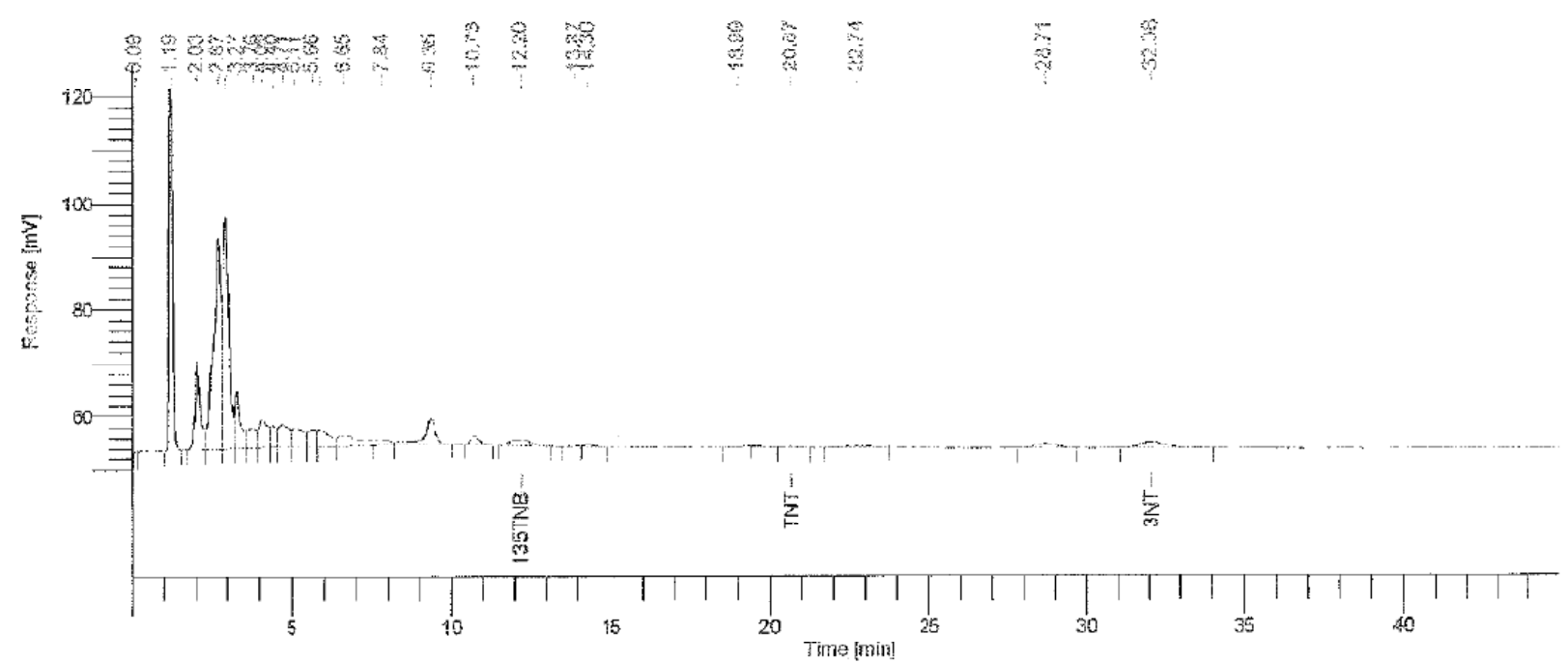

Figure 65- HPLC-UV chromatogram from analysis of sample WVU_2007_19_MI (second run in triplicate)

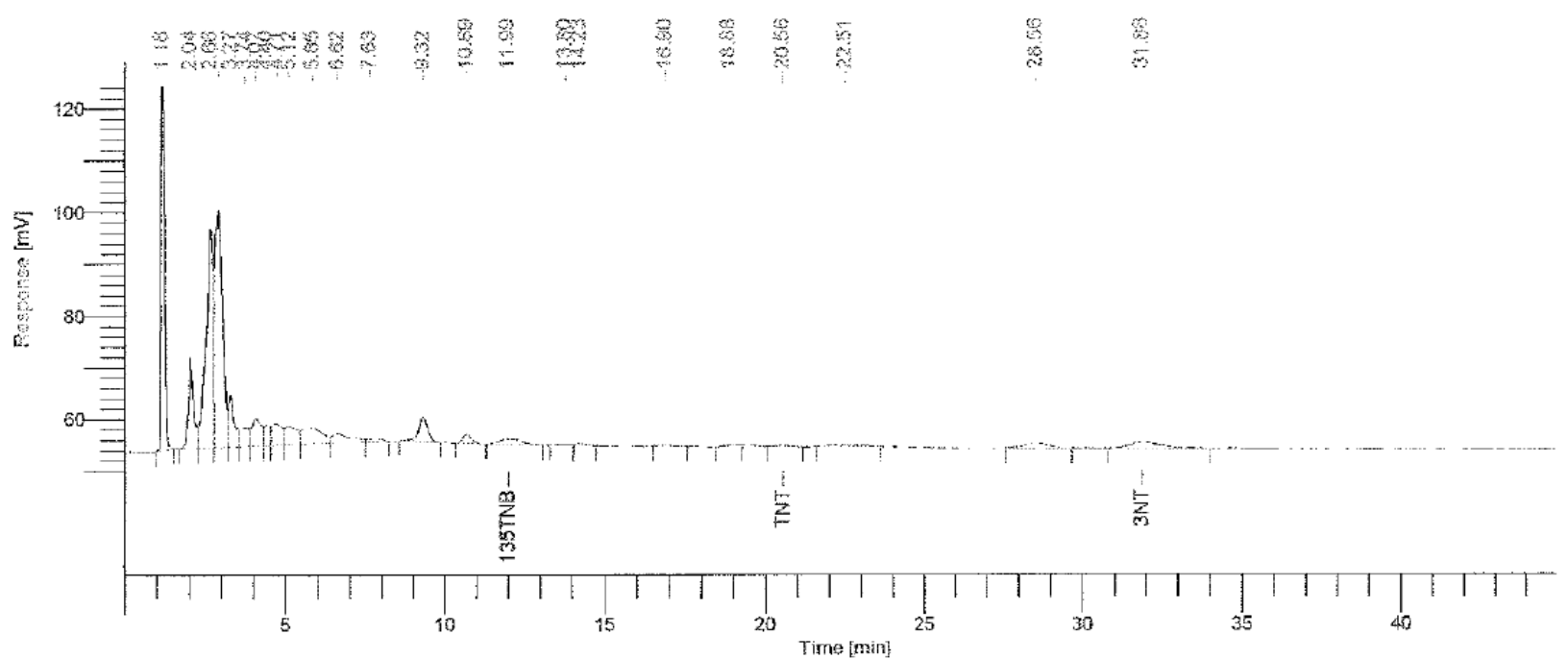

Figure 66- HPLC-UV chromatogram from analysis of sample WVU_2007_19_MI (third run in triplicate)

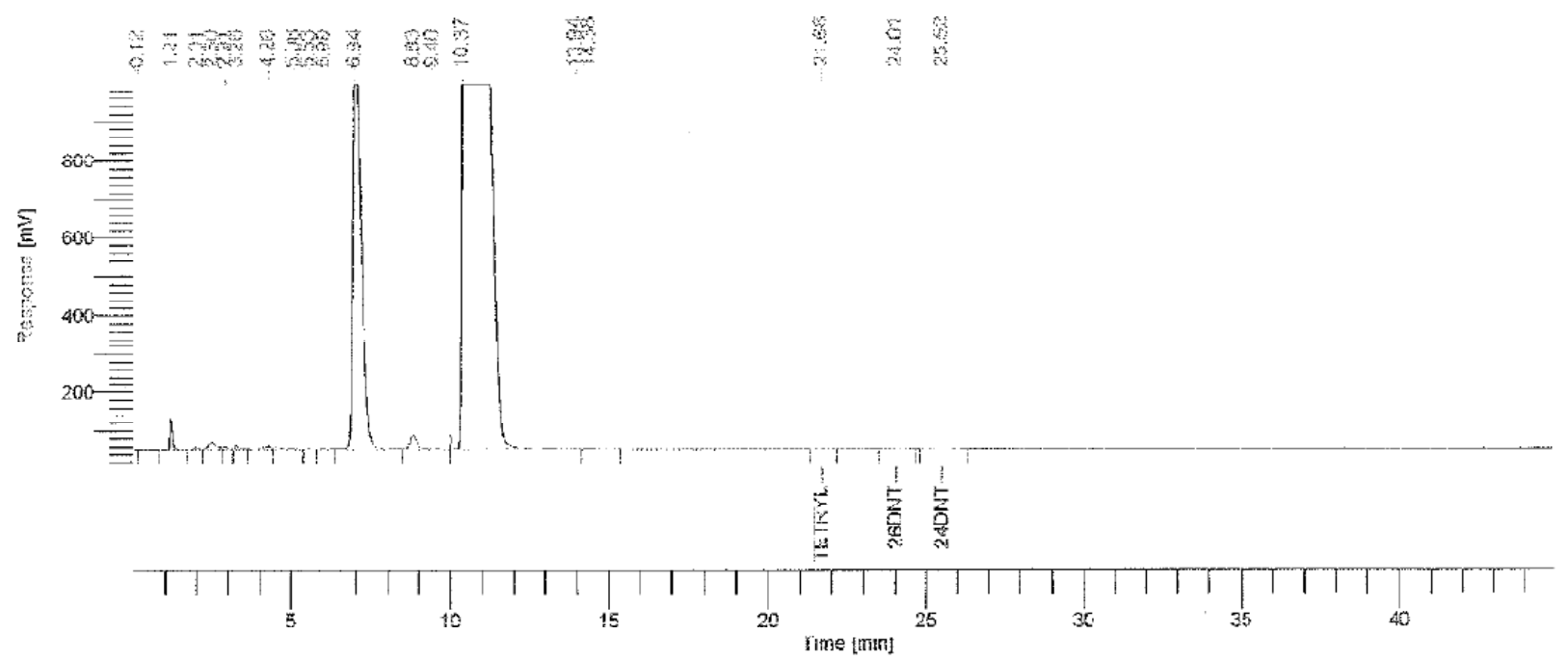

Figure 67- Representative HPLC-UV chromatogram from the analysis of sample WVU_2007_20_GRAB 


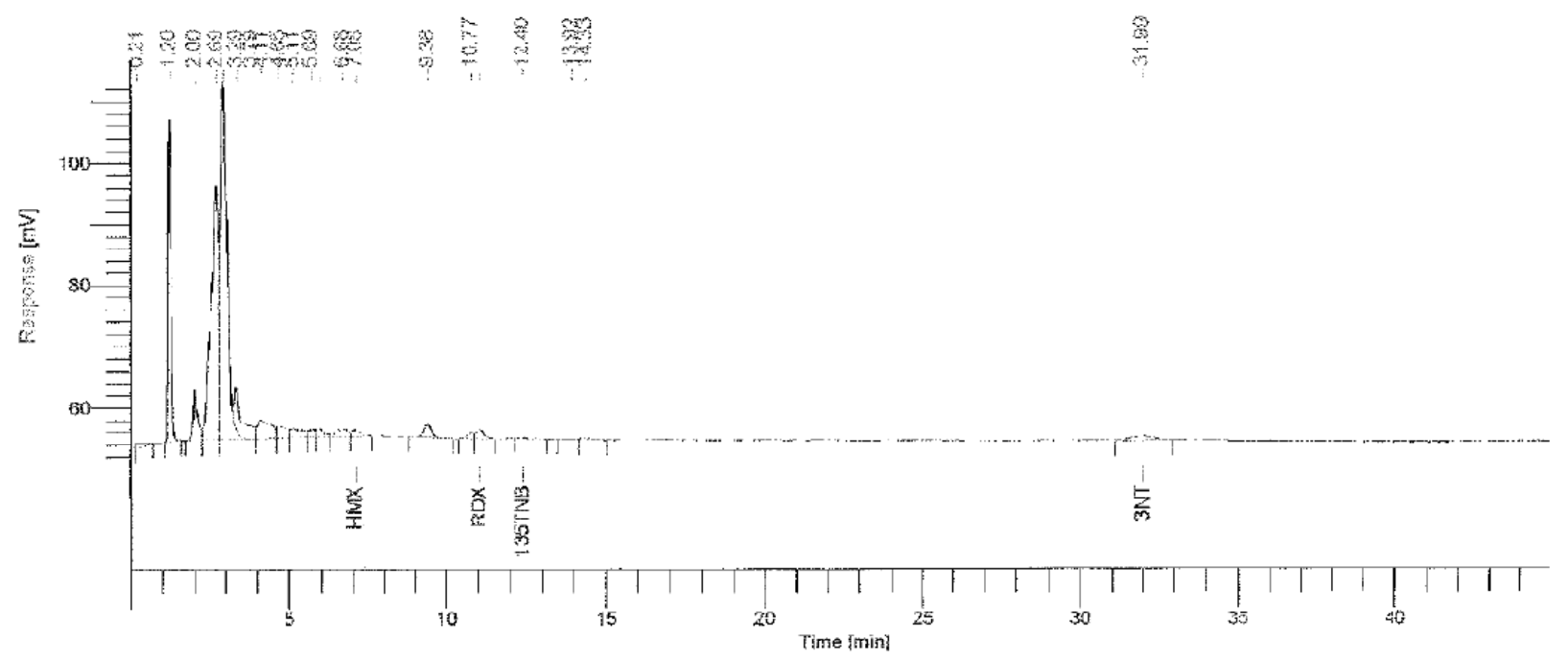

Figure 68- Representative HPLC-UV chromatogram from analysis of sample WVU_2007_20_MI_1

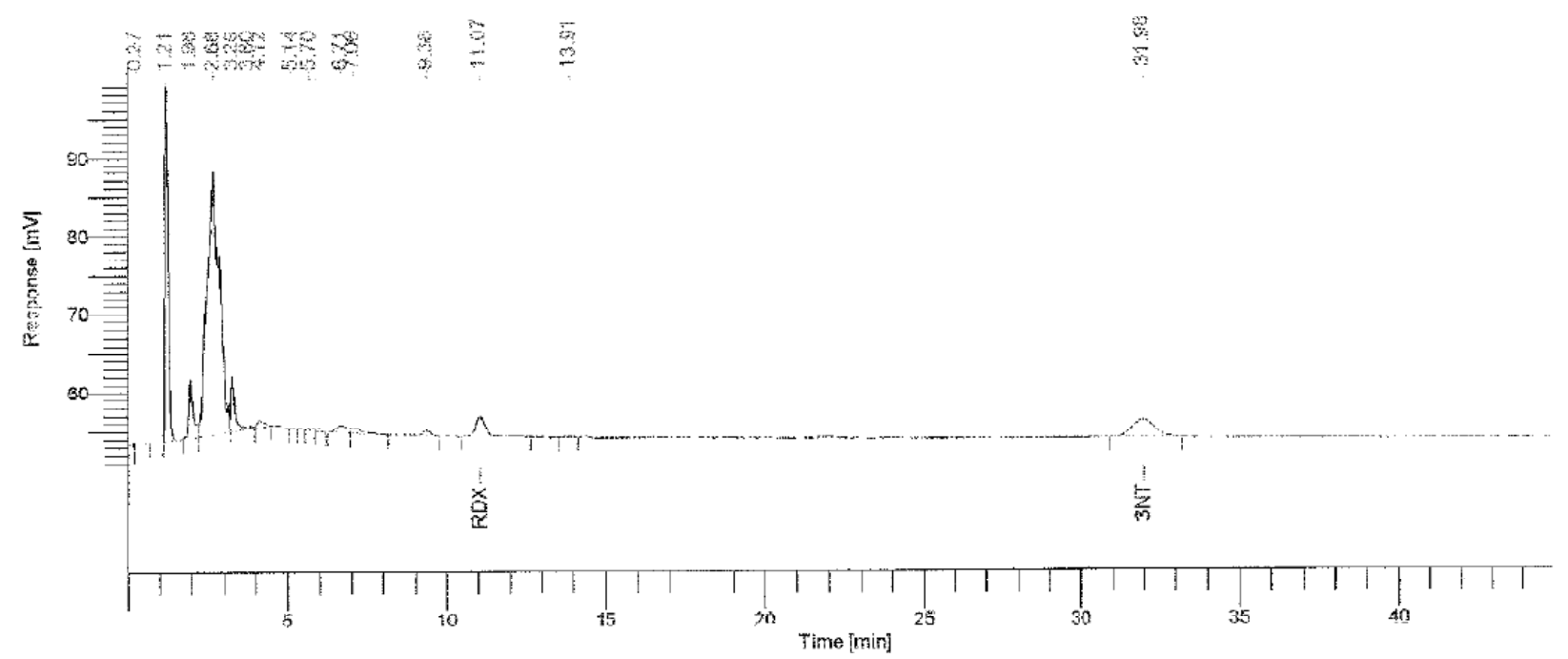

Figure 69- Representative HPLC-UV chromatogram from analysis of sample WVU_2007_20_MI_3

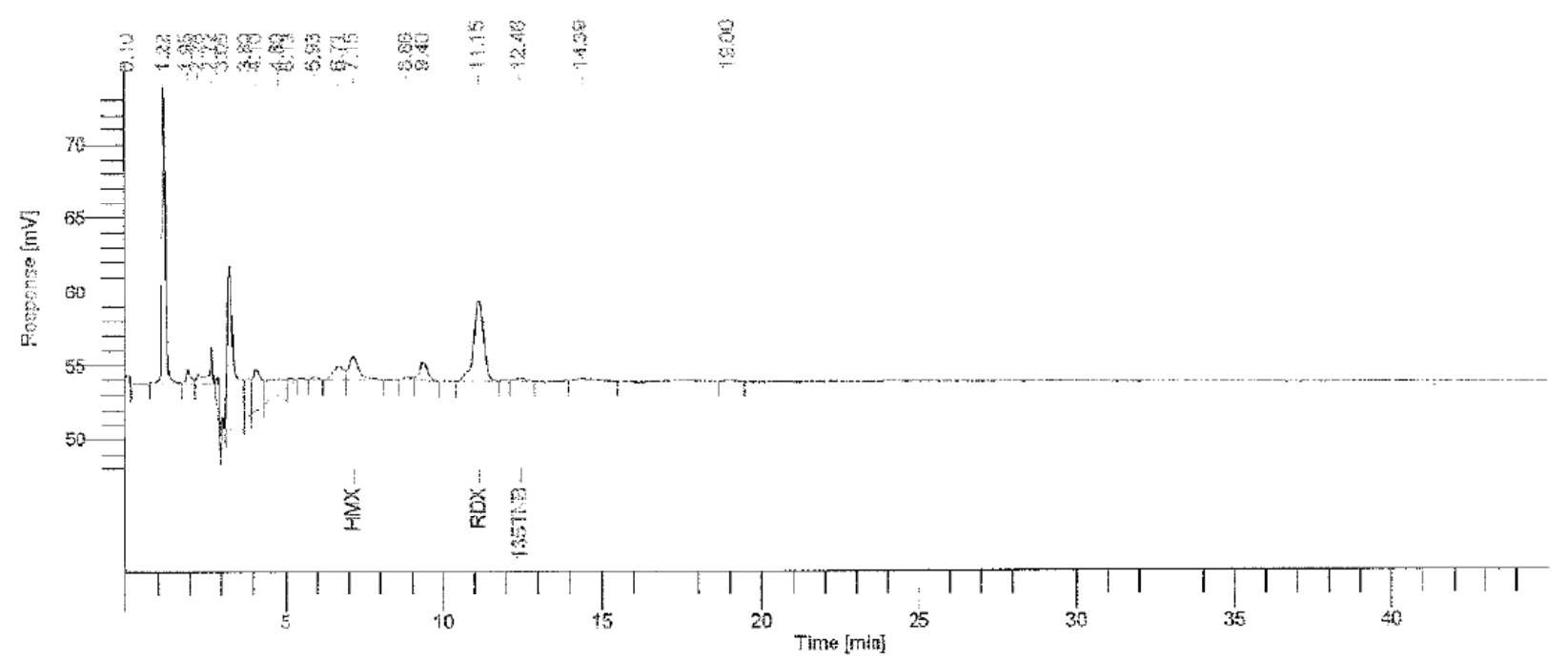

Figure 70- Representative HPLC-UV chromatogram from analysis of sample WVU_2007_20_CORE_1 


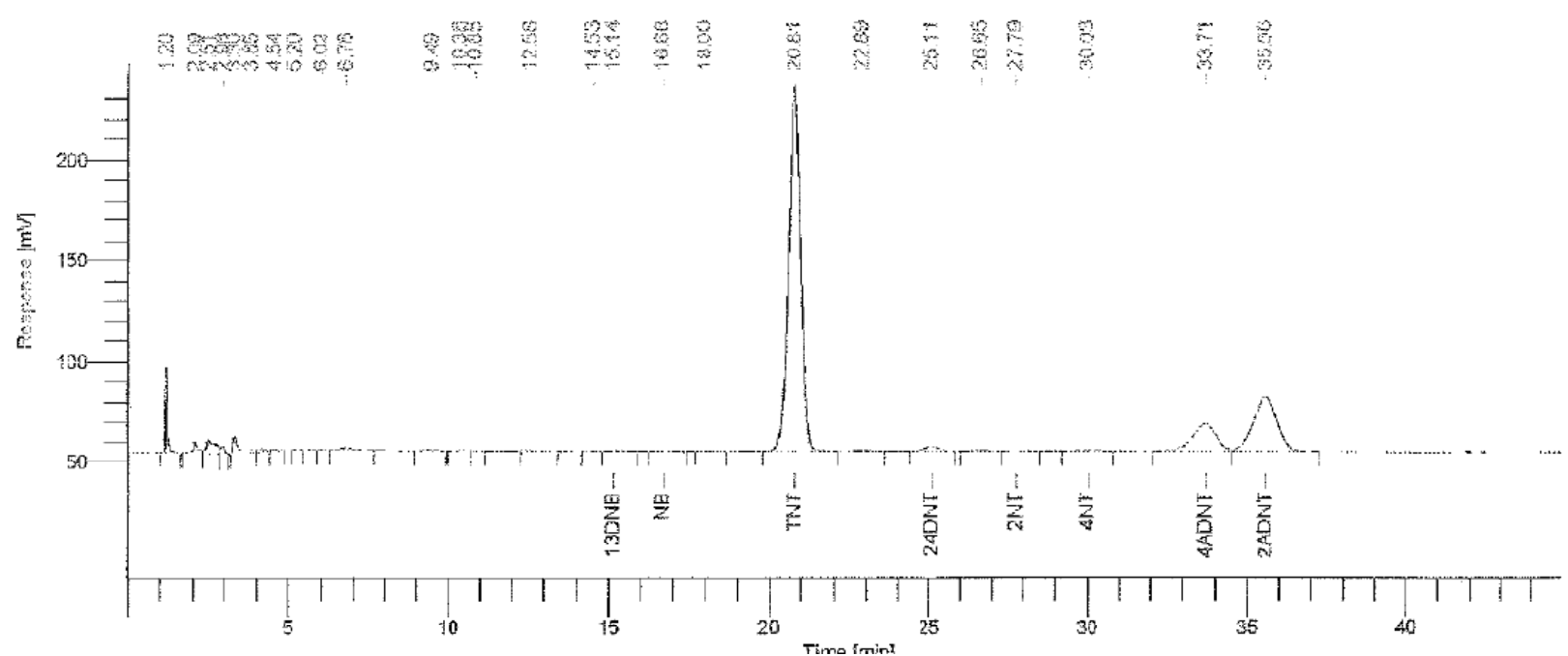

Figure 71- Representative HPLC-UV chromatogram from analysis of sample WVU_2007_XD_1

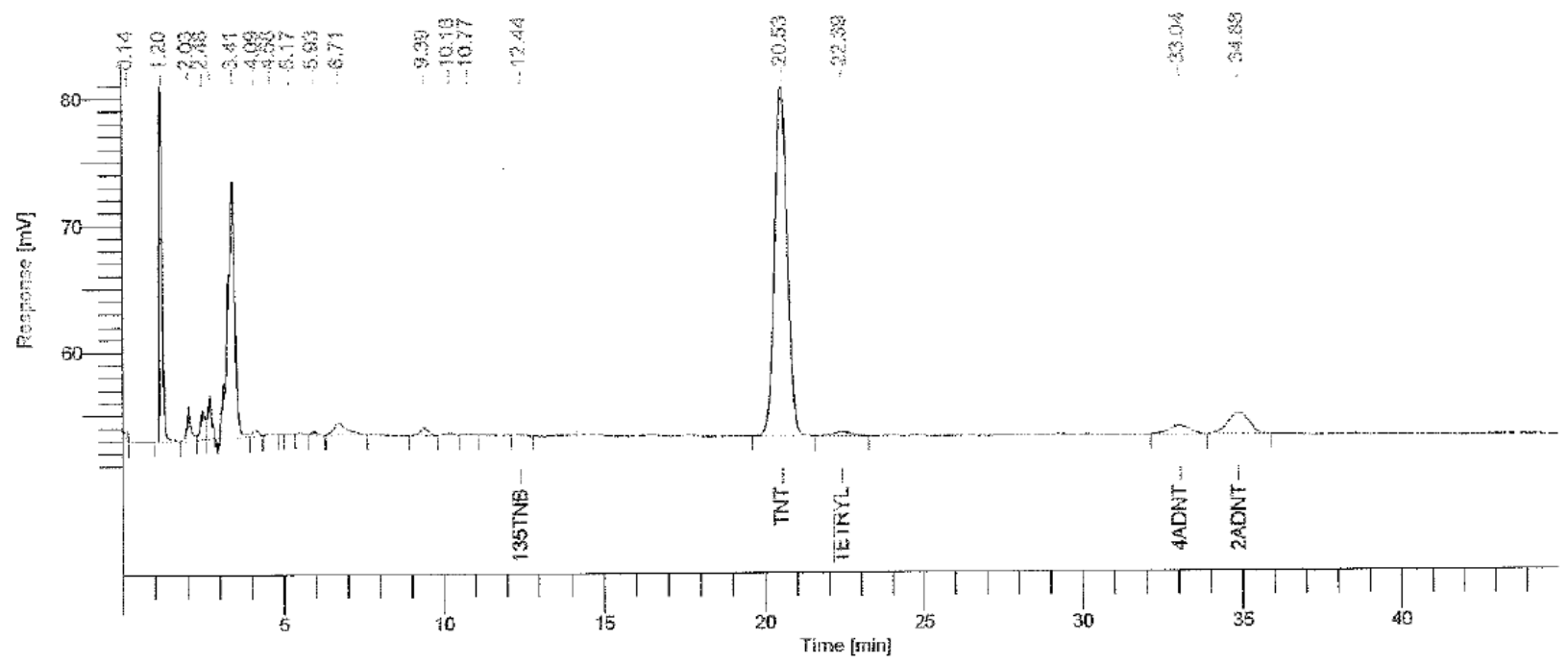

Figure 72- Representative HPLC-UV chromatogram from analysis of sample WVU_2007_XD_2

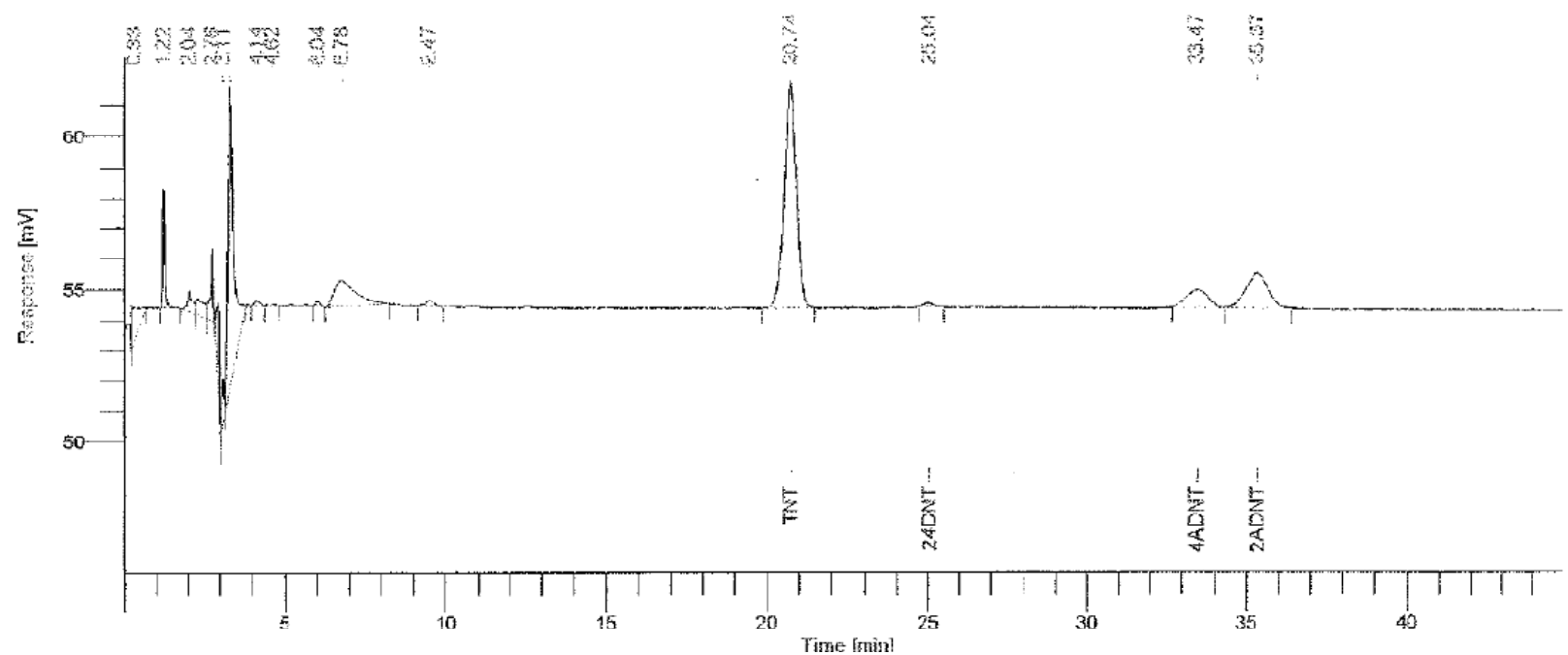

Figure 73- Representative HPLC-UV chromatogram from analysis of sample WVU_2007_XD_3a 


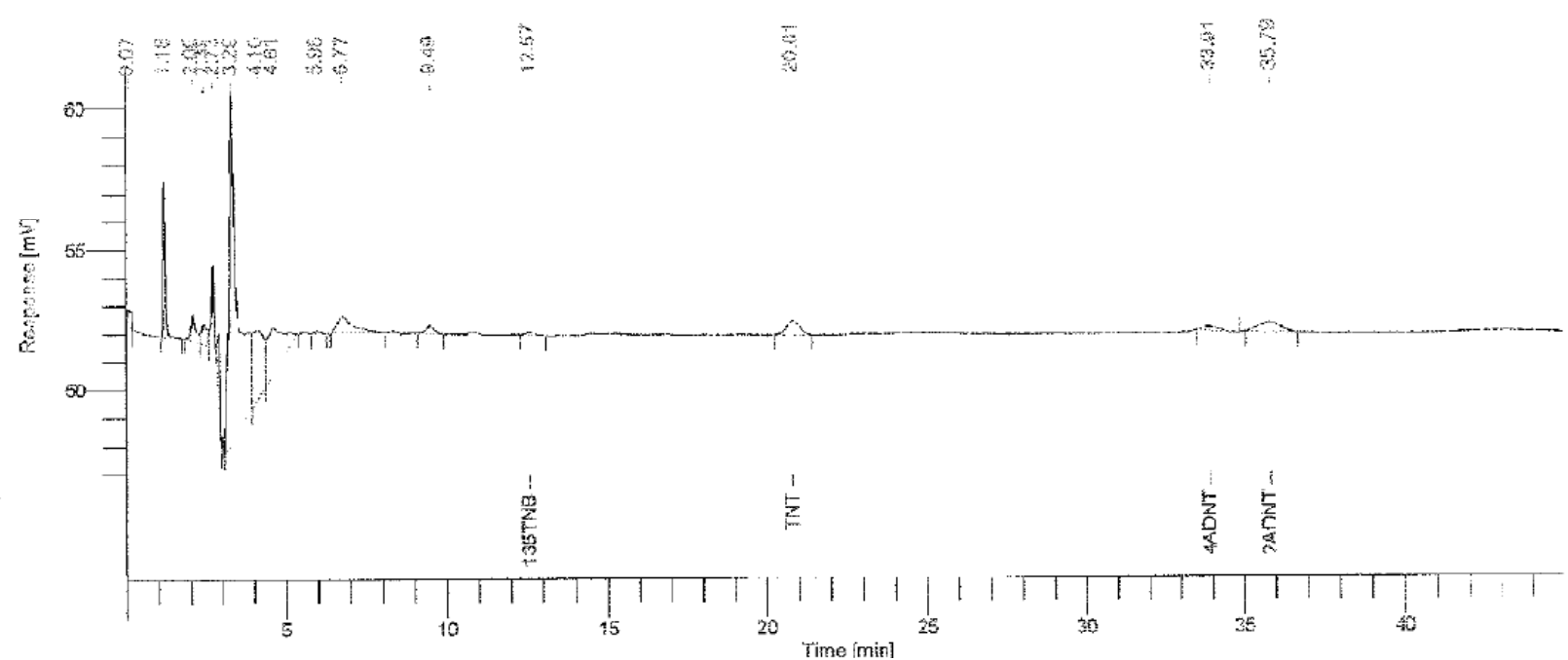

Figure 74- Representative HPLC-UV chromatogram from analysis of sample WVU_2007_XD_3b

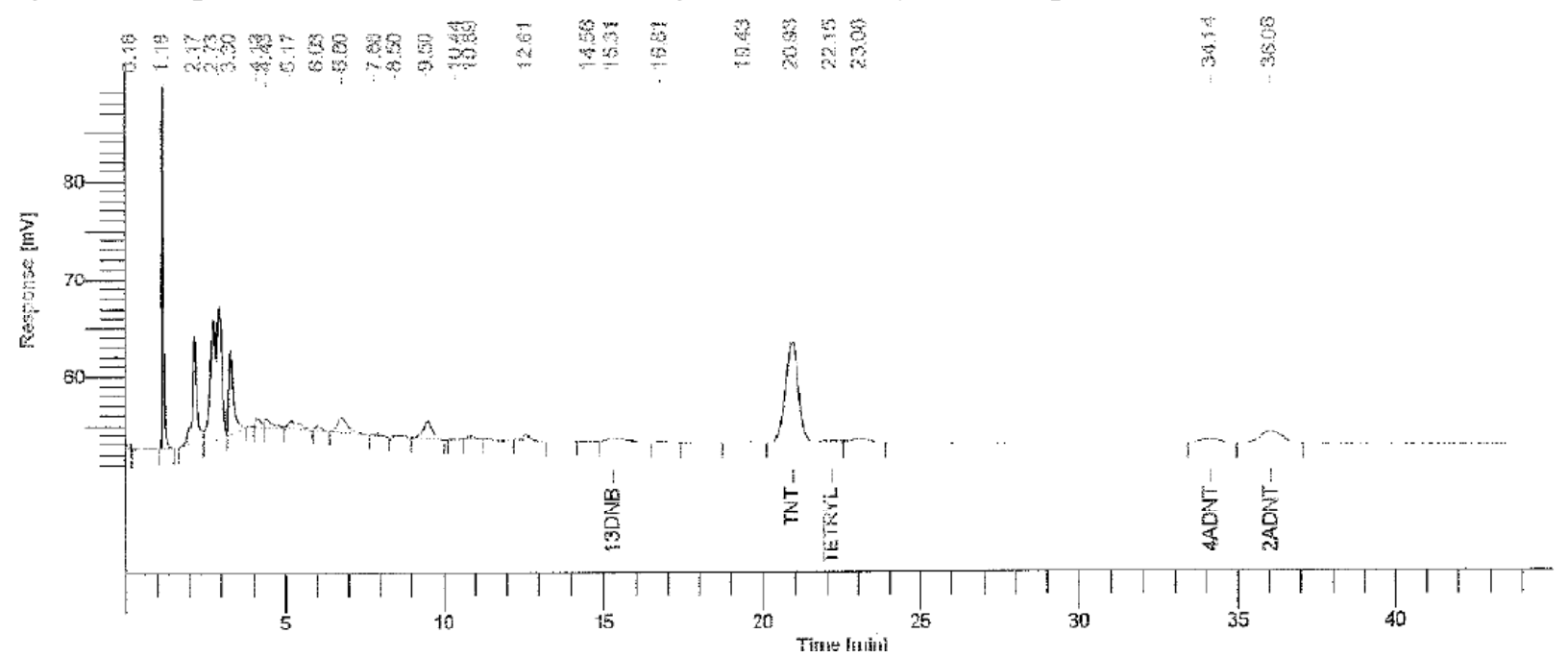

Figure 75- Representative HPLC-UV chromatogram from analysis of sample WVU_2007_XD_4

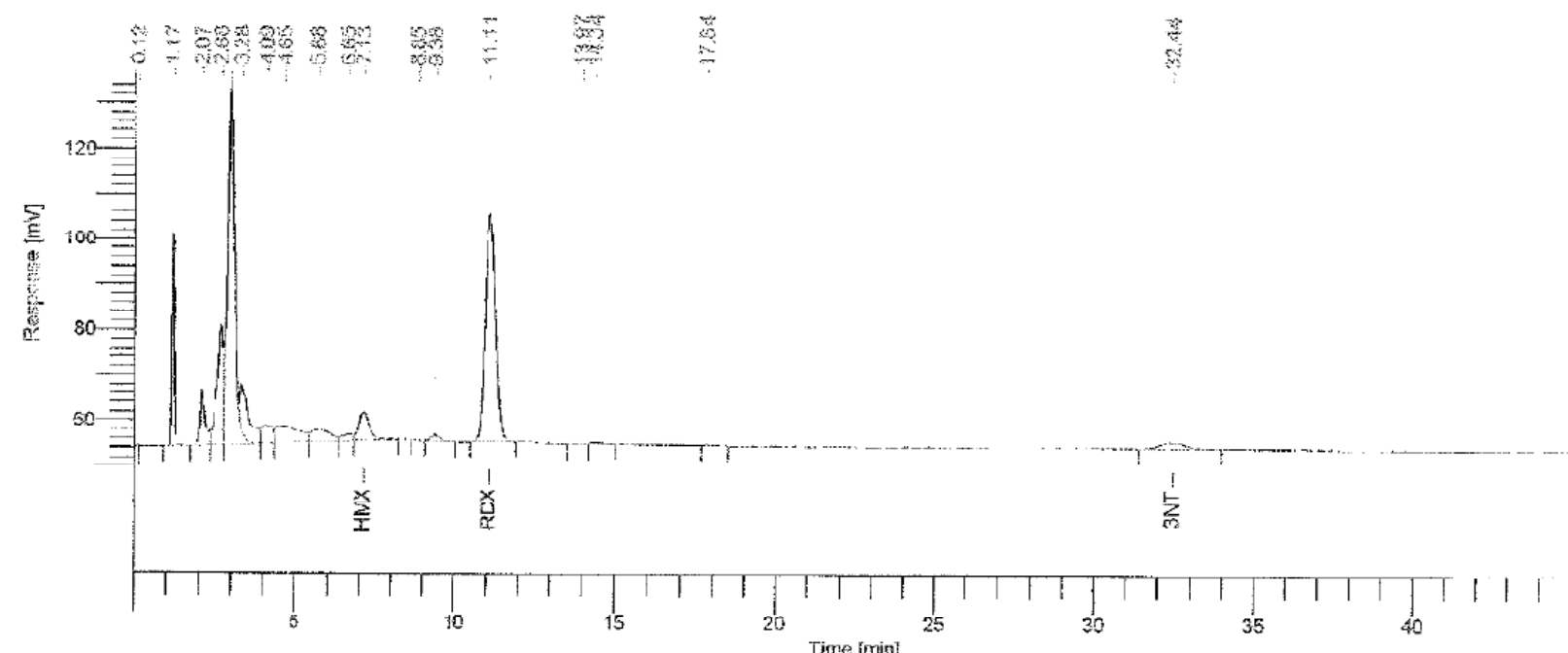

Figure 76- Representative HPLC-UV chromatogram from analysis of sample WVU_2007_20_MI_2 


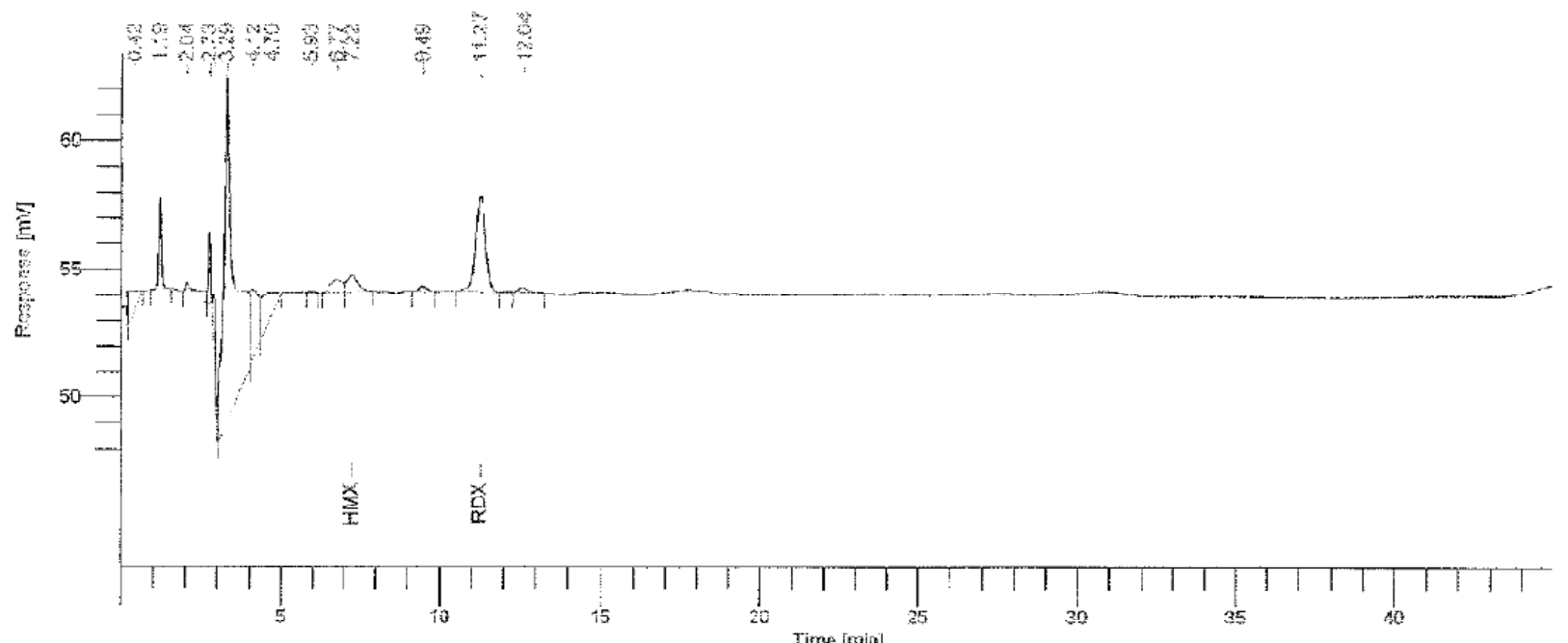

Figure 77- Representative HPLC-UV chromatogram from analysis of sample WVU_2007_20_CORE_2 